\title{
Tectonic history of the Chihuahua trough, Mexico and adjacent USA, Part II: Mesozoic and Cenozoic
}

\author{
Walter T. Haenggi \\ 2007 Tradewinds Drive, \\ Missouri City, TX 77459-2331 \\ Whaen83675@aol.com
}

\begin{abstract}
The Chihuahua trough is a right-lateral pull-apart basin that began to form $\sim 159$ to $\sim 156 \mathrm{Ma}$ (Oxfordian) during a period of relative counterclockwise rotation of the North American plate. Jurassic seas were well established by latest Oxfordian time and there was little change in basin configuration throughout the remainder of Late Jurassic, Neocomian and Aptian time. Elements of a broad zone of intersecting pre-existing northwest-trending and north-trending lineaments, along the southwest border of the North American craton, provide the fabric for development of the pullapart basin between the Diablo and Aldama platforms. During Tithonian and Neocomian time sedimentation eventually outpaced tectonic subsidence and, as an ensuing "regressive" event commenced, the eastern area of the Chihuahua trough was the locus of extensive evaporite (including halite) deposition. Near the end of Aptian time, during deposition of the Cuchillo and equivalent formations, faulting along the margins of the Chihuahua trough ceased and the seas began to transgress onto adjacent platform areas. By middle Albian time seas had advanced onto previously emergent areas and the Chihuahua trough became a site of shallow-water carbonate deposition that prevailed, with minor interruptions, until early Cenomanian time. The Ojinaga Formation (early Cenomanian -Santonian?) records a marine clastic influx into the Chihuahua trough, coeval with Upper Cretaceous clastic wedges in the Western Interior Cretaceous Seaway of the United States. Retreat of the Cretaceous sea is reflected in the transition from marine to non-marine beds in the Santonian San Carlos Formation and overlying non-marine El Picacho Formation.

During the Laramide orogeny ( 84 to $43 \mathrm{Ma}$ ) the Chihuahua trough was inverted to form the Chihuahua tectonic belt. Laramide deformation is the result of left-lateral transpressional tectonics involving renewed movement along the pre-existing fabric that controlled the location of the Jurassic-Aptian basin. In the evaporite basin portion of the trough (eastern area) reactivation of basin-boundary-faults as Laramide reverse faults, with possible left-lateral components of motion, accompanied by development of gentle "ancestral" folds, was followed by amplification of folds in postevaporite rocks caused by flow of evaporites toward the crests of anticlines. As deformation progressed, structural development involved thrust faulting (principally toward the Diablo Platform) and diapiric injection of evaporites along the margins of the evaporite basin. In the northwestern area of the trough, structure reflects northeast-southwestoriented compression and includes relatively minor southwest-directed thrusting toward and onto the Jurassic Aldama platform. Paleozoic formations are involved in the thrusts and all thrusting can be interpreted as a consequence of faulted basement rather than regional-scale décollement.

Post-Laramide tectonic activity includes a continuation of evaporite tectonism, scattered igneous intrusion, minor volcanism, gravity tectonics and late Oligocene-Miocene to Quaternary block faulting. In the eastern area of the Chihuahua trough, erosion, after formation of Laramide structure and before emplacement of Oligocene volcanic rocks, created a topography that was similar to that of the present day. During this interval, gravity-induced flaps and detached flaps developed on flanks of several large anticlines. Collapse structures, related to evaporite solution, have deformed Tertiary and Cretaceous formations in areas of diapiric intrusion along tear fault zones. Tertiary normal faulting occurred after realignment of the regional stress system from east-northeast compression to east-northeast extension $c a$. $31 \mathrm{Ma}$. Initial faulting in Chihuahua is probably coeval with inception of block faulting in Trans-Pecos Texas (about $24 \mathrm{Ma}$ ). Seismic data in the northwestern area of the trough shows that a large part of the area has been affected by Miocene normal faults that are probably coeval with some of the faulting described in the Rio Grande rift.
\end{abstract}


Extensive Neogene and some Quaternary faulting has affected the area, along the Rio Grande, between El Paso and the Big Bend. This area is the continuation of a postulated intracontinental transform along the southern edge of the Colorado Plateau and has been the locus of faulting related to right transtension during the past 24 m.y. Many of the Cenozoic fault trends of this area are along elements of the pre-existing structural fabric that influenced the development and location of the Chihuahua trough.

Keywords: Chihuahua through, stratigraphy, tectonics, Mesozoic, Cenozoic.

\section{Resumen}

La Cuenca de Chihuahua es una cuenca pull-apart de movimiento lateral derecho que empezó a formarse hace 159$156 \mathrm{Ma}$ (Oxfordiano) durante un periodo de rotación relativa de la placa de Norteamérica en sentido antihorario. Los mares jurásicos estaban bien establecidos a finales del Oxfordiano y la configuración de la cuenca tuvo pocos cambios a lo largo del Jurásico Tardío, Neocomiano y Aptiano. Estructuras de una amplia zona de lineamientos preexistentes que se intersectan, de orientación noroeste y norte, localizados a lo largo del borde suroeste del cratón de Norteamérica, proveen la fábrica para el desarrollo de la cuenca pull-apart entre las plataformas Diablo y Aldama. Durante el Titoniano y Neocomiano, la tasa de sedimentación eventualmente superó a la de subsidencia tectónica y, al iniciarse un evento "regresivo" resultante, ocurrió extensivo depósito de evaporitas (incluyendo halita) en el área oriental de la cuenca de Chihuahua . Hacia el final del Aptiano, durante el depósito de la Formación Cuchillo y formaciones equivalentes, cesó el fallamiento a lo largo de las márgenes de la cuenca de Chihuahua y los mares empezaron a transgredir las áreas adyacentes de plataforma. En el Albiano medio, los mares habían avanzado sobre áreas previamente emergentes y en la cuenca de Chihuahua inició el depósito de carbonatos de agua somera, la cual prevaleció con interrupciones menores hasta el Cenomaniano temprano. La Formación Ojinaga (Cenomaniano temprano - Santoniano?) registra un aporte de clásticos marinos hacia la cuenca de Chihuahua, sincrónico con las cuñas clásticas del Cretácico Superior en el Mar Cretácico del Interior Occidental (Western Interior Cretaceous Seaway) de los Estados Unidos. La regresión del mar cretácico se refleja en la transición de estratos marinos a no marinos en la Formación San Carlos del Santoniano y en la sobreyaciente formación no marina El Picacho .

Durante la orogenia Laramide ( 84 a $43 \mathrm{Ma}$ ), la cuenca de Chihuahua se invirtió formando el cinturón tectónico de Chihuahua. La deformación Laramide es el resultado de tectónica transpresiva con movimiento lateral izquierdo que involucró movimiento a lo largo de la fábrica preexistente, la cual controló la localización de la cuenca del JurásicoAptiano. En la porción evaporítica de la cuenca (área oriental), la reactivación de fallas limítrofes de la cuenca como fallas inversas laramídicas, con posibles componentes de movimientos izquierdos, acompañada por el desarrollo de pliegues suaves "ancestrales", fue seguida por la amplificación de los pliegues en rocas post-evaporíticas causada por el flujo de las evaporitas hacia las crestas de los anticlinales. Al avanzar la deformación, el desarrollo estructural incluyó cabalgaduras (principalmente hacia la Plataforma Diablo) e inyección diapírica de evaporitas a lo largo de las márgenes de la cuenca evaporítica. En el área noroeste de la cuenca, la estructura refleja compresión con orientación noreste-suroeste e incluye cabalgamiento menor en dirección suroeste hacia y sobre la plataforma jurásica de Aldama. Las cabalgaduras involucran a formaciones paleozoicas y todo el cabalgamiento puede ser interpretado como consecuencia de un basamento fallado y no como una zona de despegue (décollement) de escala regional.

La actividad tectónica post-laramídica incluye una continuación del tectonismo evaporítico, intrusiones ígneas dispersas, volcanismo menor, tectónica gravitacional y fallamiento en bloques del Oligoceno tardío - Mioceno al Cuaternario. En el área oriental de la Cuenca de Chihuahua, la erosión, posterior a la formación de la estructura laramídica y anterior al emplazamiento de las rocas volcánicas oligocénicas, creó una topografía similar a la actual. Durante este intervalo se desarrollaron deslizamientos y corrimientos gravitacionales en los flancos de algunos anticlinales grandes. Estructuras de colapso, relacionadas a disolución de evaporitas, deformaron las formaciones cretácicas y terciarias en áreas de intrusión diapírica a lo largo de zonas de falla de desgarre. El fallamiento normal del Terciario ocurrió después del realineamiento del sistema de esfuerzos regional, de compresión E-NE a extensión E-NE hace aproximadamente $31 \mathrm{Ma}$. El fallamiento inicial en Chihuahua es probablemente contemporáneo al inicio del fallamiento en bloques en Trans-Pecos, Texas (hace aproximadamente 24 m.a.). Datos sísmicos en el área noroccidental de la cuenca muestran que una gran parte del área ha sido afectada por fallas normales miocénicas, las cuales probablemente son contemporáneas a parte del fallamiento descrito en el rift del Rio Grande.

El área a lo largo del Río Grande, entre El Paso y el Big Bend, ha sido afectada por extensivo fallamiento del Neógeno y en parte del Cuaternario. Esta área es la continuación de una falla transformante intracontinental postulada, que se localizaría a lo largo del margen de la Plataforma de Colorado y que ha sido afectada por fallamiento relacionado a trastensión dextral durante los últimos 24 m.a. Muchos de los alineamientos de fallas cenozoicas en esta área se localizan a lo largo de elementos de la fábrica estructural preexistente que influenció el desarrollo y localización de la Cuenca de Chihuahua.

Palabras clave: Cuenca de Chihuahua, estratigrafía, tectónica, Mesozoico, Cenozoico. 


\section{Introduction}

The Chihuahua trough is a Mesozoic depositional basin occupying northeastern Chihuahua and adjacent parts of Trans-Pecos Texas, New Mexico and extreme northeastern Sonora. Part I describes pre-Mesozoic events that culminated in development of the late Paleozoic Pedregosa basin, in effect, the proto-Chihuahua trough (see Haenggi, 2001). Part II is an effort to tell the rest of the story.

The term Chihuahua trough (Figure 1) includes the area where a Late Jurassic pull-apart basin developed in northeastern Chihuahua and adjacent parts of Texas, New Mexico and Sonora. In latest Aptian and Albian time there was a general marine transgression onto adjacent emergent areas. The Late Jurassic - Aptian Chihuahua trough joined the Bisbee basin toward the northwest and was connected to the Sabinas basin and Mar Mexicano to the southeast and south (see inset in Figure 1). The Chihuahua trough of this paper has arbitrary southern and northwestern boundaries separating it from the Sabinas and Bisbee basins (Figure 1). The southern boundary of the trough is along a portion of the boundary of the North American craton as defined by lead isotope data (James and Henry, 1993) and along the Alamitos lineament, a feature of uncertain tectonic significance observed on Space Shuttle and satellite imagery sub-parallel to and inboard (northwest) of the lead isotope boundary. The northwestern boundary of the trough is along the $109^{\circ}$ meridian.

\section{Late Jurassic basin}

Upper Jurassic rocks in the Sabinas basin, Chihuahua trough and Bisbee basin indicate that the Chihuahua trough is part of a Jurassic marine basin extending from the Gulf of Mexico to southeastern Arizona (Figure 2). West of the Chihuahua trough, in Sonora and Arizona, Oxfordian and/or Kimmeridgian ammonites are described from the Chiricahua Mountains, Arizona (Lawton and Olmstead, 1995, Olmstead and Young, 2000), near Cucurpe, Sonora (Rangin, 1977), and east of Arivechi, Sonora (Almazán-Vázquez and Palafox-Reyes, 2000). The distribution of Jurassic rocks in Chihuahua, Sonora, Arizona, New Mexico and Texas is interpreted as the result of deposition in two northwest-trending arms of the Mar Mexicano (Figure 2).

The Chihuahua trough is generally interpreted to be the result of a Jurassic extensional event that also developed the contiguous Bisbee and Sabinas basins (see Busby-Spera and Kokelaar, 1991; Fackler-Adams et al., 1997; and Lawton et al., 1997). There is general agreement that extension is related to the opening of the Atlantic Ocean and specifically to formation of the Gulf of Mexico. Extension probably commenced sometime during Middle Jurassic time and by late Oxfordian time seas extended from the Gulf of
Mexico to southeastern Arizona and into north-central Sonora (Figure 2).

The history of development of the Bisbee and Sabinas basins, while more-or-less coeval with the formation of the Chihuahua trough, is complicated by Jurassic igneous activity (including rift-related volcanism). Extensive volcanic and volcaniclastic rocks accumulated in the Bisbee basin as the basin formed - a link between Cordilleran arc magmatism and extension of the Gulf of Mexico. The basal Mesozoic unit in the Sabinas basin is a Middle Jurassic? Conglomerate with some extrusive volcanic rocks (Santamaría-O. et al., 1991) that may be related to the waning stages of a Permian-Triassic continental arc described by Torres et al. (1999). Garrison and McMillan (1999) interpreted allogenic blocks of greenschist facies metamorphic rocks in an evaporite diapir in the southeastern Sabinas basin (Laramide La Popa basin) as evidence of continental rift basalts being erupted during Jurassic time. In contrast to the Bisbee and Sabinas basins there is no known Jurassic igneous activity in the Chihuahua trough. Basalt flows do occur in a probable Jurassic formation in the Little Hatchet Mountains, New Mexico (D, Figure 2) in the extreme northwestern part of the trough (Lucas and Lawton, 2000) and extensive basal Mesozoic syntectonic conglomerate is apparently absent.

\subsection{Occurrences}

Outcrop data used to construct Figure 2, from Arizona, Chihuahua, New Mexico, Sonora and Texas, are from eleven localities where Jurassic rocks are reported and one locality (Sierra Samalayuca) where some rocks previously believed to be Jurassic are now known to be Cretaceous. Localities are discussed in the alphabetical sequence used in Figure 2. Distribution of marine Jurassic rocks and emergent areas in the Sabinas basin is based on the work of Santamaría-O. et al. (1991) and Salvador (1991). Table 1 lists sixteen wells that have encountered Jurassic rocks and Table 2 lists selected wells where Jurassic rocks are absent. Outcrop localities and wells, shown by Figure 2, where Upper Jurassic marine rocks are absent will not be described; in each case Lower Cretaceous rocks are in sedimentary contact with pre-Jurassic rocks.

\subsubsection{Locality A, Pozo Serna, Sonora}

Salvador et al. (1992) cited Beauvais and Stump (1976) who described an 1,800-1,900 m thick section of marine rocks composed of interbedded arkosic to lithic sandstones, shales and calcareous shales, and tuffaceous beds at Pozo Serna. According Salvador et al. (1992) the section contains a rich fauna indicating a late Oxfordian to early Kimmeridgian age; they noted that, "the rare "Pseudocadaceras," a Boreal Callovian genus, is also listed" (by Stump). Imlay (1980, p. 31) discussed Pozo Serna under Kimmeridgian and said that Idoceras and 





Amoeboceras occur together in $155 \mathrm{~m}$ of the section; he cited a 1973 written communication from T.E. Stump as his reference.

There is considerable doubt about the presence of Late Jurassic forms at Pozo Serna. Calmus et al. (1997) while noting reports of Late Jurassic forms, stated that "return to the localities and new outcrops of ammonites provided an abundant fauna that allows to [sic] propose an Early and Middle Jurassic age for the lower part of the Jurassic section of Pozos de Serna." It is not clear whether they collected at the same localities as Beauvais and Stump, or are questioning identification of the Late Jurassic forms. Pálfy and González-León (2000) reported that a fault-bounded Jurassic block at Pozo de Serna contains Lower Pliensbachian ammonites and González-León (2001, written communication) has informed me that he, Jósef Pálfy and David Taylor collected ammonites from the Pozo Serna section that are representative of Lower Jurassic rocks (Sinemurian, Pliensbachian and Toarcian). This most recent and continuing work (Pálfy and Taylor are studying the collection) suggests that Upper Jurassic rocks do not occur at Pozo Serna and that previous identification(s) of Late Jurassic ammonites is in error.

\subsubsection{Locality B, Cucurpe area, Sonora}

Imlay (1980) reported that he identified [for Rangin] late Oxfordian ammonites from 100-150 m of black shale overlying a thick section of interbedded volcaniclastic rocks and andesites (Rangin, 1977).

\subsubsection{Locality C, Chiricahua Mountains, Arizona}

In the northern part of the mountains ("Martyr window") Lawton and Olmstead (1995) described a 920-m section of rocks assigned to the Jurassic. The section is divided into three formations, a basal 25-m "Glance" conglomerate, overlain by the Crystal Cave Formation consisting of limestone (containing basalt flows), shale, volcaniclastic, pillow lava and siltstone/mudstone members (in ascending order), that is overlain by interbedded mafic lava flows, siltstones and thin arkosic sandstones of the Onion Saddle Formation. The shale member of the Crystal Cave Formation (Basin Trail Member) yielded an assemblage of spores, pollen and microplankton of late Callovian to Oxfordian age plus several middle Oxfordian ammonites. The volcaniclastic member (East Turkey Creek Volcaniclastic Member) contains a Callovian-Oxfordian microfossil assemblage and lower Kimmeridgian ammonites. Age of the Onion Saddle Formation is somewhat in doubt but Lawton and Olmstead reported Late Jurassic palymorphs from it and suggested that it is a Tithonian-Berriasian unit. Lawton and Olmstead (1995, Figure 2) suggested that the Glance conglomerate and Crystal Cave units range in age from Callovian to Tithonian.

\subsubsection{Locality D, Little Hatchet Mountains, New Mexico} Lawton and Olmstead (1995) correlated the Jurassic section of the Chiricahua Mountains to rocks in the Little Hatchet Mountains mapped by Zeller (1970) as "Unnamed Cretaceous? beds" and included in the Broken Jug Limestone of Lasky (1947). Lucas and Lawton (2000), reported that studies of fossils collected from the Broken Jug Formation were not completed but they suggested a Late Jurassic age. The Broken Jug Formation includes a 234 to $288-\mathrm{m}$ thick basalt member that contains interbeds of sandstone, siltstone and conglomerate (Lucas and Lawton, 2000). According to Lucas and Lawton, Harrigan (1995) described the basalt as alkali basalt with high $\mathrm{TiO}_{2}$, high $\mathrm{MgO}$ and trace-element chemistry similar to oceanisland basalt.

\subsubsection{Locality E, Sierra del Águila, Chihuahua}

Reyeros de Castillo (1974) reported on Jurassic corals west of Sierra del Águila. The "Plano Geológico Minero Chihuahua" (Sociedad Geológica Mexicana, 1985), "Carta Geológica de la Republica Mexicana" (Ortega-Gutiérrez et al., 1992), and "Plano Geológico Preliminar Region Norte del Estado de Chihuahua" (PEMEX unpublished, no date) show Upper Jurassic outcrops in the area of Sierra del Águila. Gómez (1983) in a paper on the Sierra del Águila cited Reyeros de Castillo but did not recognize Jurassic rocks (his "oldest" outcrops were assigned to the Lower Cretaceous Cuchillo Formation); the occurrence of Jurassic rocks there remains in doubt.

In an effort to determine whether or not Jurassic rocks are present in the Sierra del Aguila area, during April, 2002, W.T. Haenggi, J.L. Wilson, T.F. Lawton and W.D. Raatz collected corals from a locality about five kilometers north of the Juárez - Nueva Casas Grandes highway and about one kilometer west of the Río Casas Grandes. The corals have been sent to the New Mexico Museum of Natural History and Science (S.G. Lucas) for identification.

\subsubsection{Locality F, Sierra Samalayuca, Chihuahua}

Regional geologic maps show Upper Jurassic rocks on both flanks of the Sierra Samalayuca anticline. Díaz (1956), Ramírez-M. and Acevedo-C. (1957), and CantúChapa (1970) reported Kimmeridgian and/or Portlandian (Tithonian) ammonites from a 125-150 m section of claystone, sandstone, and limestone about two kilometers north of Sierra Samalayuca. The Jurassic age of these rocks is questionable because Berg (1969) stated, "A recent restudy [by Keith Young] shows that the age of the ammonites from the "Jurassic" rocks is Neocomian." According to Young (1969), "the Jurassic is not known [in Chihuahua] north or northeast of the vicinity of Placer de Guadalupe, unless the Jurassic at Sierra de Ojo Caliente, stop 4 of trip A-13, $20^{\text {th }}$ International Geological Congress (Díaz, 1956, p.31, Fig. 4) has been correctly dated"; Keith Young has verified the current accuracy of this statement (personal communication, 2000). 


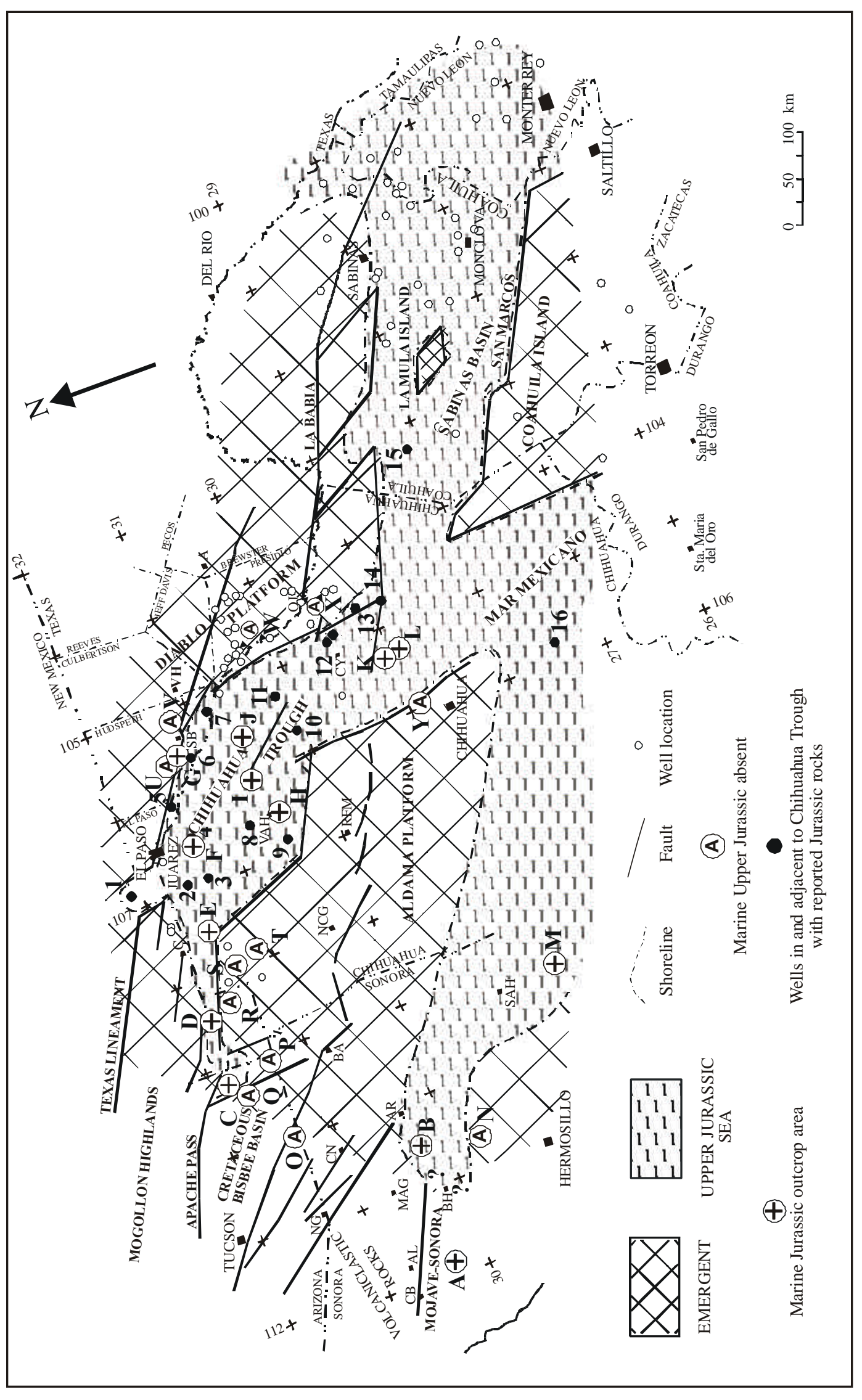

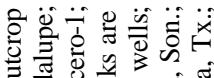

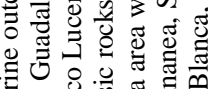
ส

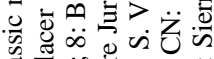

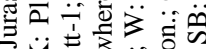

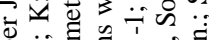

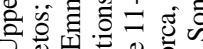

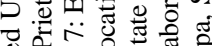

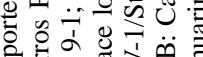

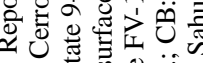

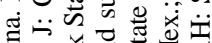

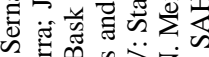

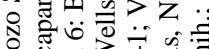

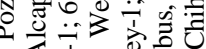

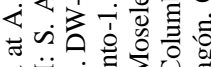

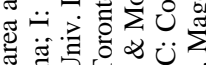

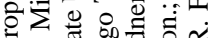

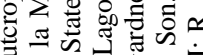

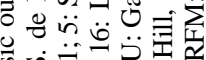

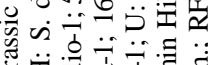

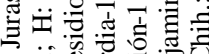

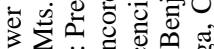

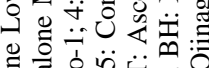

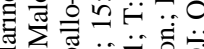
$\sum_{0}=\bar{c}$ बें

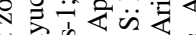

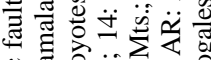

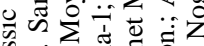

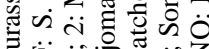

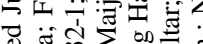

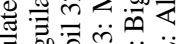
声

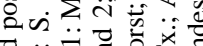

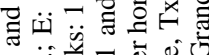
すँ

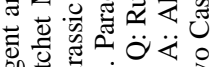

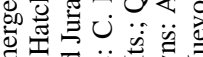

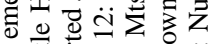

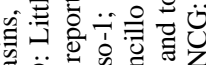

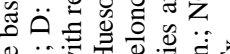

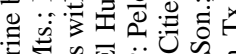

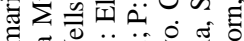

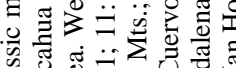

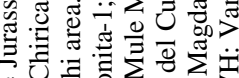
U

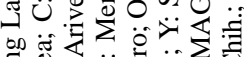

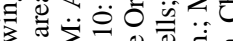

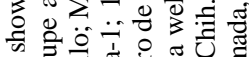

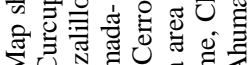
$\Sigma U$.

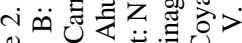

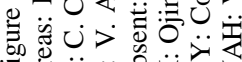


Table 1. Wells penetrating Jurassic rocks in the study area.

\begin{tabular}{|c|c|c|c|c|}
\hline & $\begin{array}{c}\text { Well } \\
\text { (map symbol) }\end{array}$ & $\begin{array}{l}\text { Thickness } \\
\text { (m) }\end{array}$ & Comment & Data source \\
\hline 1 & $\begin{array}{l}\text { Grimm et al. } \\
\text { MOBIL 32-1 (32-1) }\end{array}$ & 91 & $\begin{array}{l}\text { Oxfordian marine overlain by Albian. } \\
\text { Only occurrence Albian on Jurassic. }\end{array}$ & $\begin{array}{l}\text { Thompson and Bieberman, 1975; } \\
\text { Thompson, } 1982 .\end{array}$ \\
\hline 2 & $\begin{array}{c}\text { PEMEX } \\
\text { MOYOTES-1 (MOY-1) }\end{array}$ & 1,030 & 230 m. Unit “A”, 800 m La Casita & $\begin{array}{l}\text { PEMEX files, 1973; } \\
\text { Thompson et al., } 1978 .\end{array}$ \\
\hline 3 & $\begin{array}{c}\text { PEMEX } \\
\text { SAPALLO-1 (SAP-1) }\end{array}$ & $1,475+$ & TD in Jurassic. & Thompson et al., 1978. \\
\hline 4 & $\begin{array}{c}\text { PEMEX } \\
\text { PRESIDIO-1 (PR-1) }\end{array}$ & 1,744 & $\begin{array}{l}\text { Base picked at brachiopod occurrence; } \\
\text { no change in lithology. }\end{array}$ & $\begin{array}{l}\text { PEMEX files, 1973; } \\
\text { Thompson et al., } 1978 .\end{array}$ \\
\hline 5 & $\begin{array}{l}\text { Humble ST. UNIV. } \\
\text { DW-1 (ST DW) }\end{array}$ & $484+$ & $\begin{array}{l}\text { Top is at thrust fault, common gypsum. } \\
908 \mathrm{~m} \text { in hanging wall of thrust, } \\
320 \mathrm{~m} \text { Jurassic ? in footwall ( } 268 \mathrm{~m} \text { anhydrite). }\end{array}$ & $\begin{array}{l}\text { PEMEX files, 1973; } \\
\text { Uphoff, } 1978 .\end{array}$ \\
\hline 6 & $\begin{array}{l}\text { Border Explor. } \\
\text { BASK STATE 9-1 (BSK-9) }\end{array}$ & 908 & TD in Jurassic (common anhydrite). & Lithology and electric logs. \\
\hline 7 & $\begin{array}{c}\text { Texaco } \\
\text { EMMETT-1 (EM) }\end{array}$ & $1,644+$ & TD in Unit "A". & Lithology and electric logs. \\
\hline 8 & $\begin{array}{l}\text { PEMEX } \\
\text { B. LUCERO-1 (BL-1) }\end{array}$ & $325+$ & La Casita. & $\begin{array}{l}\text { PEMEX files, 1973; } \\
\text { Thompson et al., } 1978 .\end{array}$ \\
\hline 9 & $\begin{array}{l}\text { PEMEX } \\
\text { V. AHUMADA-1 } \\
\text { (VA-1) }\end{array}$ & 710 & La Casita & $\begin{array}{l}\text { PEMEX files, 1973; } \\
\text { Thompson et al., } 1978 .\end{array}$ \\
\hline 10 & $\begin{array}{l}\text { PEMEX } \\
\text { MENONITA-1 } \\
(\text { MEN-1) }\end{array}$ & 500 & La Casita & Dyer, (1987, p. 18). \\
\hline 11 & $\begin{array}{c}\text { PEMEX } \\
\text { EL HUESO-1 (EH-1) }\end{array}$ & $1,983+$ & $\begin{array}{l}\text { Steep dips; } 270 \text { m Unit “A” (common } \\
\text { anhydrite/gypsum), } 1409 \text { m Unit "B", } \\
\text { TD in } 110 \text { Ma rhyolite. }\end{array}$ & PEMEX files, 1973. \\
\hline 12 & $\begin{array}{l}\text { PEMEX } \\
\text { C. PARADO } 1 \text { and } 2 \\
(\mathrm{CP}-1 ; \mathrm{CP}-2)\end{array}$ & $2,590+$ & CP-1 $60 \%$ salt, CP-2 several salt sections. & Ramírez-M. and Acevedo-C., 1957. \\
\hline 13 & $\begin{array}{c}\text { PEMEX } \\
\text { MAIJOMA-1(MJ-1) }\end{array}$ & $250-399$ & $\begin{array}{l}250 \text { m from Limón-González; } \\
399 \text { m from López-Ramos. }\end{array}$ & $\begin{array}{l}\text { Limón-González, } 1986 \text {; } \\
\text { López-Ramos, } 1988 .\end{array}$ \\
\hline 14 & $\begin{array}{c}\text { PEMEX } \\
\text { APACHE-1(AP-1) }\end{array}$ & 1,292 & La Casita & $\begin{array}{l}\text { Limón González, 1986; } \\
\text { López-Ramos, } 1988 .\end{array}$ \\
\hline 15 & $\begin{array}{c}\text { PEMEX } \\
\text { CONCORDIA-1 }\end{array}$ & 270 & $\begin{array}{l}\text { "La Casita" (López-Ramos); Santamaria-O. } \\
\text { et al. mention Olvido or Zuloaga equivalent. }\end{array}$ & $\begin{array}{l}\text { López-Ramos, 1988; } \\
\text { Santamaría O. et al., } 1992 .\end{array}$ \\
\hline 16 & $\begin{array}{c}\text { PEMEX } \\
\text { L TORONTO-1 }\end{array}$ & 300 & La Casita & López-Ramos, 1988. \\
\hline
\end{tabular}


Table 2. Wells in the study area with Jurassic rocks absent

\begin{tabular}{|c|c|c|c|}
\hline$\underset{\text { Mymbol }}{\text { Map }}$ & Well & Comment & Data Source \\
\hline ASC-1 & PEMEX Ascención-1 & Hell-to-Finish on Permian & Thompson et al., 1978. \\
\hline ST BA & Humble No. 1 State "BA" & Hell-to-Finish on Permian & Zeller, 1965. \\
\hline B FW & $\begin{array}{l}\text { Gulf First Nat. Bnk. } \\
\text { Ft. Worth St.-1 }\end{array}$ & $\begin{array}{l}\text { Cox on Permian; Permian on } \\
\text { Precambrian Carrizo Mtn. Gr. }\end{array}$ & Gulf Oil Co., pre-1984, personal communication. \\
\hline BSOE & West Bledsoe-1 & Yucca on Permian & Gulf Oil Co., pre-1984, personal communication. \\
\hline $\mathrm{CH}-1$ & PEMEX Chapo-1 & Cretaceous on Paleozoic? & Ramírez-M. and Acevedo-C., 1957. \\
\hline $\mathrm{CH}-2$ & PEMEX Chapo-2 & Cretaceous on Permian? & Díaz, 1964. \\
\hline ESP-1 & PEMEX Espia-1 & Hell to Finish on Permian & $\begin{array}{l}\text { Thompson et al., 1978; PEMEX files, 1973, per- } \\
\text { sonal communication. }\end{array}$ \\
\hline G\&M-1 & $\begin{array}{l}\text { Western States et al. } \\
\text { Gardner \& Moseley-1 }\end{array}$ & $\begin{array}{l}\text { Campagrande (Cretaceous) on } \\
\text { Permian }\end{array}$ & Albritton and Smith, 1965 \\
\hline G PTR & Gulf Presidio Trust- 1 & Cox on Permian & Gulf Oil Co., pre-1984, personal communication. \\
\hline HPTR & $\begin{array}{l}\text { Hunt Presidio Trust } \\
\text { "Toodle"-1 }\end{array}$ & Yucca on Permian & Gulf Oil Co., pre-1984, personal communication \\
\hline OJ-1 & PEMEX Ojinaga-1 & "Las Vigas" on Devonian & $\begin{array}{l}\text { Cantú-Chapa et al., (1985); Limón-González, } \\
\text { (1986); López-Ramos (1988) }\end{array}$ \\
\hline P ST & ARCO Presidio State-1 & Cretaceous on Permian & $\begin{array}{l}\text { Gulf Oil Co., pre-1984, personal communication; } \\
\text { DeJong and Addy (1992) }\end{array}$ \\
\hline ST FV & Texaco State "FV"-1 & $\begin{array}{l}\text { Yucca on Permian; Permian on } \\
\text { Precambrian Carrizo Mtn. Gr. }\end{array}$ & Texaco, 1998, personal communication (well logs) \\
\hline ST 11-1 & $\begin{array}{l}\text { Border Exploration State } \\
\text { "11"-1 }\end{array}$ & $\begin{array}{l}\text { Yucca on Permian; Permian on } \\
\text { Precambrian Carrizo Mtn. Gr. }\end{array}$ & Texaco, 1998, personal communication (well logs) \\
\hline $\mathrm{S} \mathrm{SCH}$ & $\begin{array}{l}\text { Gulf State School } \\
\text { "Lo"-1 }\end{array}$ & $\begin{array}{l}\text { Yucca on Permian according to } \\
\text { PEMEX data }\end{array}$ & $\begin{array}{l}\text { Gulf Oil Co., pre-1984, personal communication; } \\
\text { PEMEX files, 1973, personal communication. }\end{array}$ \\
\hline SWAF & Gulf Swafford-1 & Cox on Permian & Gulf Oil Co., pre-1984, personal communication. \\
\hline THX-1 & $\begin{array}{l}\text { Haymond Krupp } \\
\text { Thaxton-1 }\end{array}$ & Bluff/Yucca on Permian & $\begin{array}{l}\text { Albritton and Smith (1965); Pearson (1980); } \\
\text { Cannon (1940). }\end{array}$ \\
\hline W PTR & $\begin{array}{l}\text { West Presidio } \\
\text { Trust-1 }\end{array}$ & Cox on Permian Alta Fm. & Gulf Oil Co., pre-1984, personal communication. \\
\hline WC PTR & $\begin{array}{l}\text { West \& Cockburn } \\
\text { Presidio Trust-1 }\end{array}$ & $\begin{array}{l}\text { "Las Vigas/Yucca/Etholen" on } \\
\text { Permian Cibolo Formation }\end{array}$ & Gulf Oil Co., pre-1984, personal communication. \\
\hline
\end{tabular}




\subsubsection{Locality G, Malone Mountains, Texas}

Occurrence of marine Jurassic rocks in the Malone Mountains is well known. Albritton and Smith (1965) described the Malone Formation as 119 to $305 \mathrm{~m}$ of a mixture of many different kinds of rocks that are divided into a lower member composed of sandy shale, siltstone, sandstone, and conglomerate and a predominantly limestone upper member; the formation thins southeastward along the trend of the mountains. Invertebrate fossils are scattered throughout the formation, Kimmeridgian ammonites occur in the lower member and Tithonian forms are found near the top of the formation.

Several workers, most recently Tickner (1987), have considered fossils from the Malone Formation to be Cretaceous. Albritton and Smith (1965, p. 35-37) discussed the controversy (The Malone Controversy) over the ages of faunas from the Malone Formation in considerable detail. Their summary reported that all workers accept that the ammonites from the formation are Jurassic but that many of the pelecypods are considered to be Cretaceous by several authors, e.g., Burckhardt (1930). In the opinion of Albritton and Smith (1965) the controversy was settled by Stoyanow (1949) who wrote, “...the presence of Trigoniae with such strong Cretaceous affinities in the strata of Malone age is quite unique. It does not imply a later age than Jurassic for the strata in which these Trigoniae occur in a close association with the Malone ammonites, but it certainly foreshortens the perspective of the time span which separates these strata from the Cretaceous and through which the development of the Trigoniae of the established types continued uninterruptedly."

The entire Malone Mountains are in the hanging wall of a thrust fault system that has displaced the Jurassic rocks a minimum of 7 to $8 \mathrm{~km}$ from the Chihuahua trough toward the Diablo Platform. Hennings (1991) estimated $7 \mathrm{~km}$ of shortening in a balanced section drawn along seismic line "FM" immediately north of the Malone Mountains. To the south, along the same thrust system, Smith (1940, p. 630) estimated $7.25 \mathrm{~km}$ as the minimum horizontal displacement. In contrast, Berge (1982) suggested a minimum of $24 \mathrm{~km}$ of tectonic transport and suggests that actual transport may be as much as $80 \mathrm{~km}$. Figure 2 shows the Malone Mountains in their present position.

\subsubsection{Locality H, Sierra de La Mina/Ojo Caliente, Chi- huahua}

Díaz (1956) and Ramírez-M. and Acevedo-C. (1957) assigned about $150 \mathrm{~m}$ of black claystone and limestone to the Upper Jurassic and note that Mazalpilites, a diagnostic Kimmeridgian ammonite, occurs 50 to $75 \mathrm{~m}$ above the base of the exposed section. A Lower Cretaceous unit, "very similar to the Torcer Formation of the Malone Mountains" conformably overlies Jurassic rocks (Díaz, 1956). Dyer (1987, p. 18, Km. 164.6) stated that, "the sediments at the base of the section were previously reported as Kimmeridgian age but recent studies have demonstrated that they contain an Aptian fauna."

\subsubsection{Locality I, Sierra de la Alcaparra, Chihuahua}

Rodríguez-Torres, (1969) recognized diapiric gypsum and assigned it to the Jurassic Loma Blanca Formation. He proposed the name Aleja Formation for $162 \mathrm{~m}$ of metasomatized limestone and shale that is inferred, by stratigraphic relations, to be Tithonian or Neocomian; the Aleja Formation is conformable with the overlying Neocomian Alcaparra Formation. Ramírez-M. and Acevedo-C. (1957) reported an approximately 100-m section of black claystone and limestone that contains impressions of bivalves and cephalopods similar to those found in a Kimmeridgian/Portlandian (Tithonian) assemblage in Sierra Ojo Caliente.

\subsubsection{Locality J, Cerros Prietos, Chihuahua}

Araujo-Mendieta and Casar-González, (1987) reported a 109-m thick incomplete section of Jurassic rocks. The section is predominantly sandstone and silty sandstone with scarce siltstone and bentonitic tuff. Their measured section shows Idoceras zacatecanum and Idoceras aff. Mutabile near the base of the section and they assigned the unit an early Kimmeridgian age.

\subsubsection{Locality K, Placer de Guadalupe, Chihuahua}

This is by far the best known Jurassic locality in Chihuahua and age of the units is discussed by numerous authors, e.g., Bridges (1962, 1964a); Imlay (1980); Araujo-Mendieta and Casar-González (1987). The Jurassic La Casita Formation is about 1,000 m of alternating shale, shaly limestone, limestone and sandstone beds. Near Minas Plomosas an atypical basal conglomerate, derived from underlying Paleozoic rocks, ranges from 2 to $150 \mathrm{~m}$ thick and rests on rocks as old as Pennsylvanian. In Part I of this paper (Haenggi, 2001) a small Jurassic island is postulated over a late Paleozoic fold in this area; Araujo-Mendieta and Casar-González (1987) also proposed a Jurassic island (Isla de Guadalupe) here during Kimmeridgian time. Kimmeridgian ammonites are found near the base of the La Casita and Tithonian forms are common near the top of the formation.

\subsubsection{Locality L, Cerro Carrizalillo, Chihuahua}

Roberts and Dyer (1988) described a 1,000-m thick sequence of rocks that they assigned to the La Casita Formation. They subdivided the formation into three facies: 1) basal fluvial (conglomerate); 2) shelf to basinal (vast majority of formation, common turbidites); and 3) gypsum (youngest). A shallow(?) water limestone/ shale unit that may be in all, or part equivalent to the Neocomian Navarrete Formation, overlies the La Casita with apparent conformity. The basal Jurassic conglomerate consists of clasts (pebble to occasional boulder size) of angular to subangular rhyolite, rounded limestone and angular to subrounded quartzite, ranging in thickness from 1-2 $\mathrm{m}$ to $40 \mathrm{~m}$. Ammonites that are presumed to be 
Late Jurassic are first found in a 50-m interbedded sandstone and shale section (lower shelf deposits) overlying the conglomerate.

\subsubsection{Locality M, Arivechi area, Sonora}

Almazán-Vázquez and Palafox-Reyes (2000) described a 950-m thick Mesozoic section in a nappe, partially covering Lower Cretaceous rocks, about $7 \mathrm{~km}$ east of Arivechi, Sonora. An ammonite from the section was identified as Subdichotomoceras, a Kimmeridgian index fossil.

\subsection{Bisbee Basin}

Northwest of the Chihuahua trough, in the Bisbee basin, the Glance Conglomerate is a consequence of extensional events that formed the basin. Bilodeau et al. (1987) described the Glance as alluvial fan deposits along the margins of a series of separate, west-northwest trending graben and half-graben basins. Thickness varies from absent to several thousand meters with large variations over short distances. Over an area that extends about $200 \mathrm{~km}$ west of Figure 1 the age of the Glance varies from late Middle Jurassic to Lower Cretaceous. A welded tuff interbed in the Glance of the Canelo Hills (60 km south-southeast of Tucson) has yielded a latest Kimmeridgian Rb-Sr age (151 \pm 2 Ma, Vedder, 1984). In the Chiricahua Mountains (C, Figure 2) of southeastern Arizona the Glance conglomerate is interpreted to be as old as Middle Jurassic (Lawton and Olmstead, 1995) because the overlying Crystal Cave Formation contains Oxfordian ammonites and other early Late Jurassic forms. Lawton and Olmstead (1995) described the Crystal Cave Formation as a succession of limestone, shale, sandstone, mafic flows and volcaniclastic rocks greater than $700 \mathrm{~m}$ thick that records late Middle - early Late Jurassic marine transgression, maximum flooding and regression with accompanying subaerial intrabasinal volcanic eruptions. In the Pajarito and Las Guijas mountains, near Arivaca, Arizona (50 km south of Tucson), and to the west, in the Baboquivari Mountains, there are fairly extensive exposures of Early and/or Middle Jurassic volcanic, hypabyssal and sedimentary rocks (Riggs and Haxel, 1990). Volcanic rocks are chiefly rhyolitic and rhyodacitic ignimbrites and are interbedded with diverse clastic rocks including eolian arenites; hypabyssal rocks are granite and rhyolite.

In Arizona, Cretaceous Bisbee Group rocks (including the Glance conglomerate) occur over the entire southeastern part of the State and the northern limit of the basin is generally shown to be along a westto west-northwest-trending line from Tucson to southernmost New Mexico (see Titley, 1976; Dickinson et al., 1986). From the Apache Pass fault (Figure 2) northward the lower, clastic, part of the Bisbee section (Glance conglomerate and Morita Formation) thins in discrete steps across faults (Lawton and Olmstead, 1995).
Toward the west the Bisbee strata are entirely nonmarine and limits of the basin are uncertain; Dickinson et al. (1986) and Fackler-Adams et al. (1997) suggested that the Bisbee Basin is coeval with the McCoy Basin of southeastern California.

Configuration of the Bisbee basin in Mexico is uncertain and, perhaps, many of the Mesozoic sediments there were deposited in a basin or basins separated from the Bisbee basin of Arizona by emergent areas. Nourse (1995) showed a possible basin configuration (Figure 8C, p. 74) and applied the term "Northern Sonora Basin" for much of the area of Sonora that is included in this discussion. Jacques-Ayala (1995) presented data and arguments to support a Late Jurassic-Aptian basin extending from the vicinity of Caborca, Sonora (CB, Figure 2) southward, through central Sonora to at least the latitude of Sahuaripa (about $29^{0} \mathrm{~N}$, see Figure 2 for location of Sahuaripa). He speculated that, at various times, this basin extended southeastward toward the Aldama platform in Chihuahua. Although Jacques-Ayala (1995) agreed with Stewart (1992) that the MojaveSonora megashear (MSM, Figure 2; Silver and Anderson, 1974) may have moved during the late Paleozoic, he argues that during Jurassic time the area was covered with volcanic rocks and that Jurassic movement of the Mojave-Sonora megashear could not have transported the Caborca terrane to its present location prior to deposition of the Bisbee Group (Jurassic-Early Cretaceous), near Caborca. His studies show a southern and western rhyolitic and andesitic provenance for the Bisbee Group rocks near Caborca with a virtual absence of sediment derived from Proterozoic and Paleozoic rocks that should have been present, if the Caborca terrane existed at the time of deposition. In Sonora, Oxfordian marine rocks near Cucurpe (Rangin, 1977) suggest development of a basin as early as latest Middle Jurassic time even after discounting the reported Oxfordian ammonites at Pozo Serna (Beauvais and Stump, 1976).

Several authors interpreted the Bisbee basin as an extension of the Chihuahua trough and ultimately of the Sabinas basin and relate basin formation to opening of the Atlantic Ocean (Dickinson et al., 1986; Lawton and Olmstead, 1995; Lawton et al., 1997; Basset and Busby, 1997; Busby-Spera and Kokelaar, 1991). Fackler-Adams et al. (1997) presented a convincing argument that development of an extensional-transtensional McCoy basin (southeastern California and western Arizona) is "broadly" coeval with formation of the Bisbee basin and was a consequence of the opening of the Gulf of Mexico; their data suggest that this basin was developing by earliest Late Jurassic time (lower McCoy Mountains Formation). Fackler-Adams et al. (1997) reconstructed the origin of Jurassic basins along the southwestern edge of North America and described a transtensional McCoy-Bisbee basin and a "rift-dominated Chihuahua trough" (that includes the Sabinas basin). In their scheme "basin formation is attributed to exploitation of a thermally weakened welt of the arc by an aulacogen 
associated with the opening of the Gulf of Mexico"; presumably the aulacogen is congruent with the basins. Dickinson and Lawton (2000) interpreted the Bisbee basin as a consequence of "Late Jurassic rifting that succeeded early Mesozoic arc magmatism and was followed by thermotectonic basin subsidence extending to midCretaceous time." They interpreted the initial rifting as the result of deformation of a subducted slab derived from consumption of an oceanic plate between the continent and a postulated Guerrero superterrane. Dickinson and Lawton (2000) suggested that longitudinal extension of the Bisbee rift belt formed the McCoy basin of California-Arizona and the Chihuahua trough and described how facies grade from exclusively non-marine in the McCoy basin, through interstratified marine and nonmarine in the Bisbee basin to exclusively marine in the Chihuahua trough. In their interpretation, the Chihuahua trough was open to the evolving Gulf of Mexico; this is consistent with the interpretations presented herein.

\subsection{Sabinas Basin}

A reddish pre-Upper Jurassic "basal" conglomerate is reported from numerous wells in the Sabinas basin (Santamaría-O. et al., 1991). This basal conglomerate is only found in the subsurface and, based on similarity to sequences to the south and southeast that contain Jurassic vertebrates and pollen, Santamaría-O. et al. (1991) interpreted it to be a Lower- to Middle-Jurassic continental deposit. Their interpretation shows conglomerate accumulating in grabens developed between a series of elevated blocks and islands; prevalent trend of basins is north $75^{\circ}$ west and rhomb-shaped islands and basins, bounded by faults trending north $15^{\circ}$ west occur throughout the area. Considerable topography is indicated because Jurassic sediments are absent on the highest structural blocks, Oxfordian rocks are found only in the lowest blocks, and Kimmeridgian-Tithonian rocks occur on "intermediate" blocks. McKee et al. (1990) described a Jurassic marine conglomerate that occupies a similar stratigraphic position to the basal conglomerate from Valle de San Marcos, immediately north of the San Marcos fault (Figure 2). Here there are about 1,600 $\mathrm{m}$ of sandstone and conglomerate (Las Palomas and Sierra El Granizo beds, base not exposed) below a section containing Tithonian ammonites (Tanque Cuatro Palmas beds).

In the extreme southeastern part of the Sabinas basin, Santamaría-O. et al. (1991) reported that eight wells found extrusive dacite, rhyodacite, andesite, trachyte and some basalt interbeds in the basal conglomerate. Garrison and McMillan (1999) interpreted the protolith of allogenic blocks of greenschist facies metavolcanic rocks in the El Papalote evaporite diapir in the Laramide La Popa basin (southeastern Sabinas basin) as Jurassic continental rift basalt. Santamaría-O. et al. (1991) reported Jurassic (Callovian) K-Ar dates from granite in
PEMEX Pecten-1 (160 \pm 6 Ma, about $20 \mathrm{~km}$ southeast of Monclova; see Figure 2 for location of Monclova) and from PEMEX Menchaca-1A (164 $\pm 7 \mathrm{Ma}$, about $60 \mathrm{~km}$ northwest of Monclova). If these dates have validity, Jurassic granite was emplaced into a terrane consisting of late Permian-early Triassic granite that extends along the Mexican coast from the central part of the Sabinas Basin to the latitude of the city of Veracruz (Salvador, 1991, Plate 3; Torres et al., 1999). If Permian-Triassic granitic rocks formed a contiguous terrane, as Salvador's map implies, it is unlikely that Mesozoic sinistral (or dextral) displacements of any magnitude have occurred along the various northwest-trending megashears postulated south of the Sabinas basin because the trend of the granites crosses the projected megashears with little or no apparent displacement; see Jones et al. (1995) for a typical argument favoring major displacement. If Jurassic dates for granites, within the PermianTriassic plutonic trend, are correct, the rather widespread pre-Oxfordian volcanogenic rocks reported by Santamaría-O. et al. (1991) and Jones et al. (1995) from north-eastern Mexico may be coeval with emplacement of granite, a tectonic setting that operated independently of the well-known Jurassic arc along the western coast of North America. Perhaps these Jurassic igneous rocks reflect a rejuvenation of whatever caused emplacement of the Permian-Triassic granites (consumption of a late Paleozoic/earliest Triassic ocean behind an advancing arc?). The Permian-Triassic granites formed subsequent to development of a late Paleozoic island arc located immediately south of the San Marcos fault (McKee et al., 1988).

\subsection{Chihuahua Trough}

With the possible exception of a thick (up to $360 \mathrm{~m}$; Ward, 1977) conglomerate, mapped as Permian Plomosas Formation, locally underlying the Jurassic La Casita Formation in the vicinity of Placer de Guadalupe (K, Figure 2), syntectonic Mesozoic basal conglomerates and coeval volcanic rocks are not recognized in the Chihuahua trough. In northwestern Chihuahua there is a basal Mesozoic conglomerate that has been called "Glance" (Brown and Dyer, 1987). This unit occurs conformably below Lower Cretaceous rocks, is generally less than $10 \mathrm{~m}$ thick and contains clasts derived from the underlying Paleozoic section. Neither this conglomerate nor the basal Jurassic conglomerate in the Placer de Guadalupe - Carrizalillo area (see description under Occurrences, Localities $\mathrm{K}$ and L) have aspects that can be ascribed to deposition in alluvial fans along faults with high relief; they are similar to the ubiquitous basal Trinity conglomerates and sandstones of Texas which are deposits along shorelines of seas advancing onto a tectonically stable area (topography capable of forming islands, peninsulas etc.).

Conclusions regarding depositional setting and 
paleogeology of Jurassic rocks in the Chihuahua trough are speculations because data are insufficient to resolve details of rapid lateral facies changes and to define significant thickness variations. At least $1,000 \mathrm{~m}$ of predominantly clastic marine sedimentary rocks were deposited in the deeper parts of the Chihuahua trough during Late Jurassic time. The oldest observed Jurassic rocks are assigned to the La Casita Formation. Near Carrizalillo (L, Figure 2) the La Casita contains a thin (less than $100 \mathrm{~m}$ ) basal fluvial facies, a very thick shelf to basinal facies and an uppermost gypsum facies (Roberts and Dyer, 1988). Here and wherever observed in the Chihuahua trough, the La Casita grades upward into a shallow-water regressive facies that persists into Neocomian time (Navarrete, Torcer, and Alcaparra formations). Extensive evaporites that form the principal décollement of the Chihuahua tectonic belt occur in this latest Tithonian-Neocomian regressive facies.

Conclusions from all of this are:

1) The Chihuahua trough developed rapidly, probably during latest Middle and earliest Late Jurassic time.

2) Topographic relief was slight, tectonic activity did not create a terrain that supplied conglomerates to extensive alluvial fans.

3) Termination of Jurassic facies and thick sections at the edges of the trough is abrupt and suggests that basin boundaries are determined by faulting; essentially the same basin boundaries persist throughout Neocomian and Aptian time. Throughout this period, sediment influx and basin subsidence were essentially balanced and some of the boundary faults eventually had very large displacements (more than $1000 \mathrm{~m}$ ).

4) With the possible exception of local basalt flows in the extreme northwestern corner of the trough (Little Hatchet Mountains, New Mexico), there is no evidence of igneous activity coeval with basin formation and development

These conclusions suggest that the origin of the Chihuahua trough is, in some way, different than that of the more-or-less coeval Bisbee and Sabinas basins.

Figure $3 \mathrm{~A}$ shows a pre-Jurassic regional structural fabric consisting of the broad zone of northwesterlytrending lineaments and intersecting north-trending zones of crustal weakness. Elements of the northwesttrending zone, along the southwest margin of the North American craton, have been recurrently active since middle Proterozoic time (Haenggi, 2001). Intermittent activity of faults of the northerly-trending zones has probably occurred over a similar time span. Figure 3B shows an interpretation of the Chihuahua trough forming as a pull-apart during right-lateral motion along northwest-trending zones of crustal weakness. All of the following discussion involving Jurassic faulting in the Chihuahua trough is speculation; there are no documented Jurassic offsets on faults within or bounding the trough.

Evidence for Jurassic right-lateral motion along the southwestern boundary of North America arise from studies of the Kane Fracture Zone that show significant changes in relative plate motion from orientation and structure of the zone (Tucholke and Schouten, 1988). A pronounced kink in the trace of the Kane and North Kane fracture zones in the Jurassic Magnetic Quiet Zone (between BSMA and Anomaly M-25) is caused by changes in relative plate motion during Late Jurassic time (see Muehlberger, 1992). After correcting the dates of Tucholke and Schouetens (1988) from the DNAG time scale (Palmer, 1983) to comply with the time scale of Gradstein et al. (1994), interpolated ages of relative plate motion, indicated by the kink are $\sim 162 \mathrm{Ma}\left(20^{\circ}-25^{\circ}\right.$ clockwise) and $\sim 159-\sim 156 \mathrm{Ma}$ ( $45^{\circ}$ counterclockwise).

Counterclockwise rotation of North America, moving away from a relatively stationary African plate, would cause right-lateral offsets along susceptible elements of the northwest-trending fabric along its boundary; North America moved toward the east relative to the accreted terranes that formed Mexico at that time.

During this interval, the Chihuahua trough was born as a pull-apart feature with its configuration controlled by a pre-existing north-trending fabric (Figure 3B). The $\sim 159-\sim 156 \mathrm{Ma}$ interval during which the trough first appeared includes essentially all of Oxfordian time (time scale of Gradstein et al., 1994)

The specific north-trending "control" fabric for the trough has been a major zone of tectonic activity since, at least late Paleozoic time. It is on trend with the present day Rio Grande rift and several major north-trending faults associated with late Paleozoic ancestral Rocky Mountains deformation (Woodward et al., 1999). The Picuris-Pecos Fault, in the central part of northern New Mexico, is interpreted to have Precambrian rightslip movement (Miller et al., 1963) suggesting that elements of the north-trending fabric have existed over a similar time interval as northwest-trending zones along the southwestern boundary of North America. The Chihuahua trough is the result of the interaction between right-lateral displacement along the Texas "zone" of Muehlberger (1980) and the north-trending fabric.

\section{Jurassic - Cretaceous stratigraphy}

An in-depth discussion of Jurassic and Cretaceous formations and correlation is beyond the scope of this paper but a short review is necessary. The reader interested in Chihuahua trough stratigraphy is referred to Ramírez-M. and Acevedo-C. (1957), Córdoba (1969), Córdoba et al. (1970), DeFord and Haenggi (1970), Cantú-Chapa et al., (1985), Monreal (1989), and Monreal and Longoria (1999) for detailed discussions of stratigraphic nomenclature and correlations.

Figure 4 shows general regional correlations and Figure 5 shows formation names and a general correlation of Upper Jurassic and Lower Cretaceous lithostratigraphic units of the Chihuahua trough; formation names used here will generally be the central Chihuahua trough 


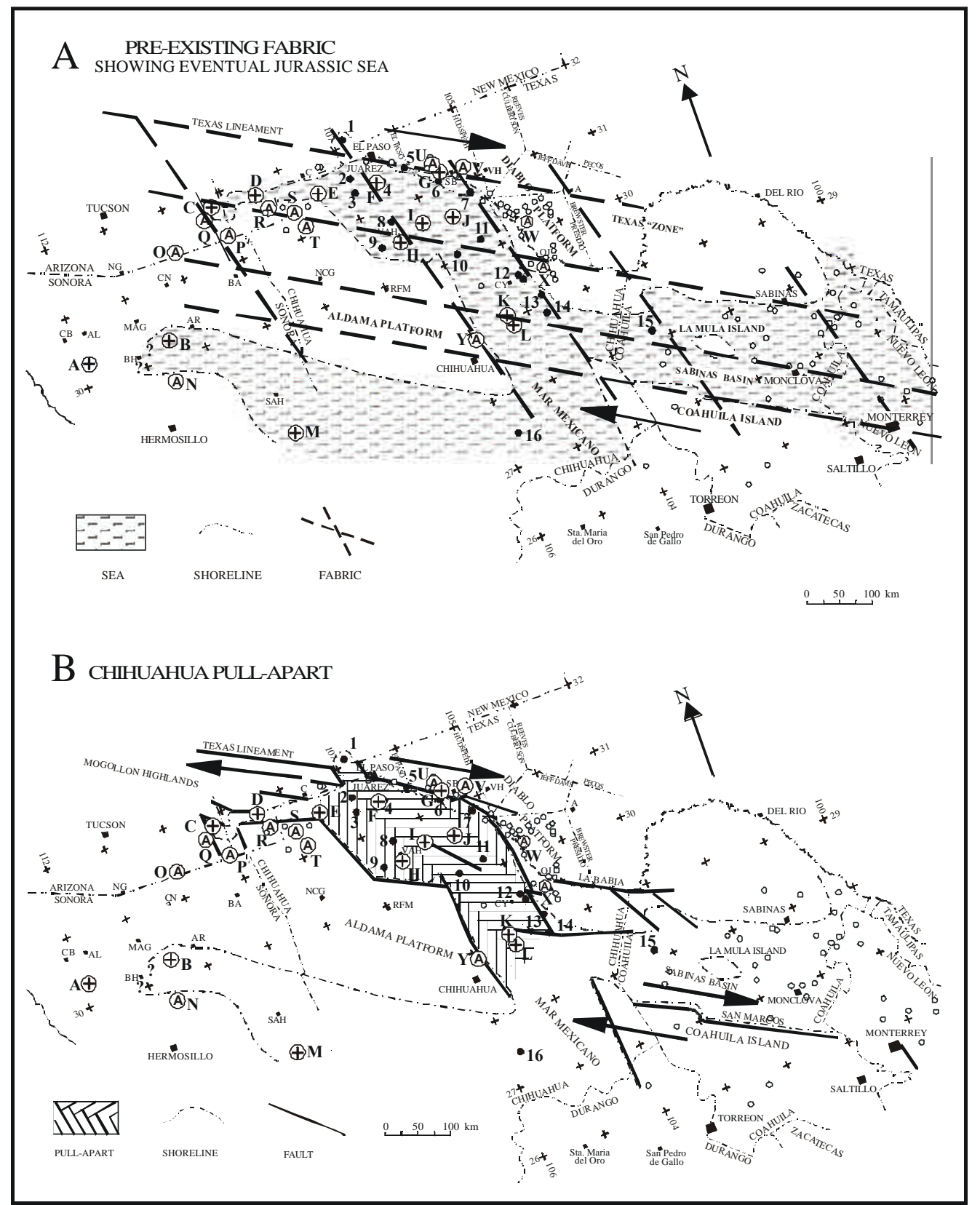

Figure 3. A. Map showing pre-Jurassic structural fabric and extent of Jurassic ocean; B. map showing mechanism for formation of Chihuahua trough as a pull-apart basin. A and B show Jurassic emergent areas; locations of marine Jurassic outcrops, wells with reported Jurassic rocks, surface locations where Jurassic rocks are absent. Symbols for wells, surface locations and cities and towns same as Figure 2.

system used by Haenggi (1966). Maximum thickness of the Jurassic-Lower Cretaceous section in the Chihuahua trough is estimated to be 4,700 $\mathrm{m}$ (Figure 6 and 7). Aptian and older stratigraphic units (La Casita Formation, evaporites, Navarrete Formation, Las Vigas Formation and part of the Cuchillo Formation) are confined to the trough. The Albian portion of the Cuchillo Formation and younger Albian formations are correlative with formations described in Trans-Pecos Texas.

The Bluff Formation (also called Bluff Mesa Forma- tion) of Trans-Pecos Texas extends into the easternmost part of the Chihuahua trough, where Haenggi (1966) mapped it in the Sierra Pilares (Figure 1). The Cox Formation, a predominantly sandstone unit, that is the lateral equivalent of the Lágrima Formation of the central Chihuahua trough, extends into the trough and is mapped in the Quitman Mountains (Jones and Reaser, 1970), Sierra Cieneguilla (Reaser, 1974), Sierra Pilares (Haenggi, 1966), Sierra Pinosa (Haenggi, 1966) and Sierra de la Parra (Haenggi, 1966; Gries, 1970); see 
Figure 1 for locations of ranges. The Finlay, Benevides and Loma Plata formations, found throughout the Chihuahua trough, are direct correlatives of Trans-Pecos Texas formations. The Cenomanian Del Rio Formation, Eagle Mountains Sandstone and Buda Limestone of Trans-Pecos Texas are found at several localities in the trough.

In addition to the Jurassic-"Lower" Cretaceous (including Del Rio - Eagle Mountains - Buda) section, an estimated 800 to $900 \mathrm{~m}$ of Upper Cretaceous (Cenomanian-Senonian) terrigenous sedimentary rock, including non-marine deposits, accumulated in the Chihuahua trough (DeFord and Haenggi, 1970). These units, where included in named formations, comprise the Ojinaga, San Carlos and El Picacho formations and form extensive outcrop areas near the eastern margin of the trough in Chihuahua and Texas. The San Carlos and El Picacho formations are apparently present only in the eastern part of the trough, along the Rio Grande, where they were deposited in the Tornillo basin, a retroarc foreland basin (Stevens and Stevens, 1990) that began to form in earliest Cenomanian time and persisted, after regression of the Mesozoic seas, into Eocene time. Scattered outcrops of the Ojinaga Formation occur in Sierra Pilares, Sierra Pinosa, and Bolson El Cuervo (Haenggi, 1966) and geologic maps show outcrops of "Upper Cretaceous" units throughout the Chihuahua trough.

\subsection{Jurassic - early Neocomian}

Araujo-Mendieta and Casar-González, (1987) described a Late Jurassic depositional history of the Chihuahua trough. Their conclusions are largely based on exposed sections in the Placer de Guadalupe Carrizalillo region, PEMEX Cuchillo Parado-1 (CP-1) and Cuchillo Parado-2 (CP-2) and scattered outcrops in the vicinity of Cuchillo Parado (Figure 1); they also incor-porated the questionable Jurassic sections near Sierra Samalayuca (F, Figure 2) and Sierra del Águila (E, Figure 2) into their interpretation. They speculated that a period of block faulting commenced prior to Kimmeridigian time, was accompanied by a marine transgression from the southeast, and ceased during early Tithonian time. After the period of faulting, evaporites were deposited in restricted portions of the eastern part of the basin. All this was followed by a general regression, accompanied by reactivation of some faults and continuation of evaporite deposition in the east, during late Tithonian time.

Cantú-Chapa et al. (1985) described a Late Jurassic marine transgression into an extensional basin with irregular but not extreme topography. Relief along margins of the basin was minimal. Kimmeridgian and Tithonian deposition is recorded by the "La Casita" and Malone formations, Oxfordian deposition is suggested by the work of Lawton and Olmstead (1995) in the Chiricahua Mountains and Oxfordian marine rocks are reportred from Grimm and Hunts' Mobil "32"-1 well (32-1) in Doña Ana County, New Mexico (Thompson and Bieberman, 1975). Sedimentation eventually outpaced tectonic subsidence of the Chihuahua trough and by latest Jurassic and/or Neocomian time a general regression, interrupted by periodic influx of marine water, ensued. During this "regressive" period shallow water, restricted lagoonal and local subaerial conditions prevailed during deposition of the evaporite facies, Navarrete, Torcer, Alcaparra and Aleja fromations.

\begin{tabular}{|c|c|c|c|}
\hline BISBEE BASIN & $\begin{array}{l}\text { SOUTHWEST } \\
\text { NEW MEXICO }\end{array}$ & $\begin{array}{l}\text { CHIHUAHUA TROUGH } \\
\text { (CENTRAL PORTION) }\end{array}$ & SABINAS BASIN \\
\hline CINTURA FM. & MOJADO FM. & $\begin{array}{c}\text { LOMA PLATA LS. } \\
\text { BENEVIDES FM. } \\
\text { FINLAY LS. } \\
\text { LÁGRIMA FM. }\end{array}$ & \multirow[t]{2}{*}{ AURORA LS. } \\
\hline-- MURAL LS.- $-\bar{r}$ & \multirow[b]{2}{*}{$\begin{array}{l}\text { ALBIAN } \\
\text { APTIAN } \\
\text { U-BAR FM. }\end{array}$} & BENIGNO FM. & \\
\hline \multirow[t]{2}{*}{ MORITA FM. } & & $\begin{array}{c}---------- \\
\text { CUCHILLO FM. }\end{array}$ & $\begin{array}{l}\text { LA PENA FM. } \\
\text { CUPIDO FM. } \\
\text { LA VIRGEN FM. }\end{array}$ \\
\hline & HELL TO FINISH FM. & LAS VIGAS FM. & SAN MARCOS FM \\
\hline $\begin{array}{l}\text { GLANCE CGL. } \\
\text { (IN PART) }\end{array}$ & $\begin{array}{l}\text { BROKEN JUG FM. } \\
\text { (IN PART) }\end{array}$ & NAVARRETE FM. & MENCHACA FM. \\
\hline
\end{tabular}

Figure 4. Chart showing generalized lithostratigraphic correlations Bisbee Basin - southern New Mexico - central Chihuahua trough - northern Sabinas Basin. 


\begin{tabular}{|c|c|c|c|c|c|c|c|c|}
\hline Age & $\begin{array}{c}\text { Malone } \\
\text { Mts. } \\
1 \\
\end{array}$ & \begin{tabular}{|c} 
Bask "9" \\
Well \\
2 \\
\end{tabular} & $\begin{array}{c}\text { S. Quitman Mts. } \\
3 \\
\end{array}$ & \multicolumn{2}{|c|}{\begin{tabular}{|c|} 
Central \\
Chihuahua Trough \\
4
\end{tabular}} & $\begin{array}{c}\text { S. Alcaparra } \\
5 \\
\end{array}$ & $\begin{array}{c}\text { Banco Lucero } \\
6 \\
\end{array}$ & $\begin{array}{c}\text { Big Hatchet Mts. } \\
7 \\
\end{array}$ \\
\hline \multirow{2}{*}{$\begin{array}{l}\text { CENO- } \\
\text { MANIAN }\end{array}$} & & & Buda & \multirow{3}{*}{ 至 } & Buda & & & \multirow{5}{*}{ Mojado } \\
\hline & & & Eagle Mountains & & Del Rio & & & \\
\hline \multirow{5}{*}{ ALBIAN } & & & Espy & & Loma Plata & Loma Plata & Loma Plata & \\
\hline & & Benevides & Benevides & $\sum_{コ}$ & Benevides & Benevides & \multirow{3}{*}{ Ahumada } & \\
\hline & & Finlay & Finlay & ㄴ. & Finlay & Finlay & & \\
\hline & & Cox & $\operatorname{Cox}$ & $\underset{⿱ 乛 龰}{2}$ & Lágrima & Lágrima & & \multirow{3}{*}{ U-Bar } \\
\hline & & Benigno & U. Mem. Quitman & & Benigno & Benigno & Lucero & \\
\hline \multirow[b]{2}{*}{ APTIAN } & & Cuchillo & $\begin{array}{c}\text { M. and L. Members } \\
\text { Quitman }\end{array}$ & & Cuchillo & Mosqueteros & & \\
\hline & & $\begin{array}{c}\text { Mountain } \\
\text { and } \\
\text { Las Vigas }\end{array}$ & $\begin{array}{c}\text { U. and M. Members } \\
\text { Mountain }\end{array}$ & & Las Vigas & Las Vigas & & Hell to Finish \\
\hline $\begin{array}{c}\text { NEO- } \\
\text { COMIAN }\end{array}$ & Torcer & Navarette & $\begin{array}{c}\text { Lower Member } \\
\text { Mountain }\end{array}$ & \multicolumn{2}{|r|}{ Navarrete } & $\begin{array}{c}\text { Alcaparra } \\
\text { Aleja }\end{array}$ & & \\
\hline \multirow{2}{*}{$\begin{array}{c}\text { LATE } \\
\text { JURASSIC }\end{array}$} & & Anhydrite & & & Evaporites & Loma Blanca & & \\
\hline & Malone & "Jurassic" & & & La Casita & & & \\
\hline
\end{tabular}

Figure 5. Chart showing Chihuahua trough nomenclature of Jurassic and Lower Cretaceous formations. References: 1: Malone Mts., Albritton and Smith (1965); 2: Bask "9" well, interpretation of well logs; 3: S. Quitman Mts., Jones and Reaser (1970); 4: Central Chihuahua trough, Haenggi (1966); 5: S. Alcaparra, Rodríguez-Torres (1969); 6: Banco Lucero, Córdoba (1969); 7: Big Hatchet Mts., Zeller (1965).

Discussion and interpretation of the presumed TithonianNeocomian evaporite sequence and of Late JurassicNeocomIan-Aptian paleogeology is an integral part of the tectonic history of the Chihuahua trough and will be addressed in some detail.

There are tantalizing clues that the Aldama platform was bounded on the south by a seaway, sub-parallel to the Chihuahua trough, that extended from the vicinity of Sierra Magistral (60 km south-southwest of Cd. Chihuahua) across the present Sierra Madre Occidental to eastcentral Sonora ( $c f$. with Jurassic seaway shown by Figure 2). Ramírez-M. and Acevedo-C. (1957) briefly described an incomplete 750-m thick section (base not exposed) of rocks in Sierra Magistral and assigned them to the Travis Peak Formation. They mentioned that the unit underlies the Glen Rose Formation (no thickness given). From their description, I conclude that parts of the Las Vigas and Cuchillo formations are present in the Sierra Magistral. If correct, this suggests that the Early Cretaceous Aldama Platform had a similar shape but was smaller (northern boundary farther to the south) than the Jurassic Aldama platform shown by Figure 2; shape, size and orientation of the Cretaceous platform is similar to the Coahuila Island (see Figure 2). In east-central
Sonora the presence of Cretaceous rocks equivalent to units in the Chihuahua trough (Scott and González-León, 1991; Monreal and Longoria, 2000) is evidence to support the postulated seaway. In the area of Lampazos, Sonora, about $35 \mathrm{~km}$ north-northwest of Sahuaripa (see Figure 2 for location of Sahuaripa), Scott and GonzálezLeón (1991) and Monreal and Longoria (2000) reported 2,500 $\mathrm{m}$ of Aptian and Albian rocks, comprising five formations, that can be correlated with formations in the Chihuahua trough. Monreal (1995) and Monreal and Longoria (2000) noted that these rocks cannot be correlated with Bisbee Group formations of Sonora and suggested a tectonic explanation (strike-slip faulting) for the "juxtaposition" of Bisbee Group and Chihuahua trough units in Sonora; a "southern" seaway connecting the Chihuahua trough to the depositional sites in Sonora seems more appropriate.

Brown and Dyer (1987) presented stratigraphic and structural evidence for middle Mesozoic vertical crustal movements in the general area of exposed Paleozoic rocks in the northwestern part of the Chihuahua trough (Sierras Palomas, Enmedio, Los Chinos, Santa Rita and La Salada; see Figure 1 for locations). Timing of tectonism is uncertain; it was, in part, coeval with 




Figure 6. Lithosomal diagram of Jurassic and Lower Cretaceous formations in Sierra Lágrima, Cañon de Navarrete, Gulf State School "LO” well and Pinto Canyon. References: S. Lágrima and C. Navarrete, Haenggi, 1966; El Hueso-1, PEMEX files, 1973; St. Sch. LO, Gulf Oil, pre-1984, personal communication; Pinto Canyon, Amsbury, 1957. 
deposition of a basal conglomerate (Glance?) and Hell-to-Finish formation (latest Jurassic?-earliest Cretaceous). Three lines of stratigraphic evidence were described by Brown and Dyer (1987): 1) pronounced unconformity between lower Permian and Cretaceous rocks; 2) irregularity of the unconformity and variability in thickness of units above and below it; and 3) coarseness and variable thickness of basal Mesozoic conglomerate (Glance?). Supporting structural evidence is the observation of a great contrast in fault density between lower Permian and Cretaceous exposures; at all localities where lower Permian rocks are exposed adjacent to Cretaceous rocks, the fault density within the Permian rocks is much greater than within the Cretaceous rocks and, in some places, faults within the Permian exposures do not extend into overlying Cretaceous rocks.
From these relationships Brown and Dyer interpreted mid-Mesozoic deformation in the form of northnorthwest-trending high-angle faulting having both normal and reverse movements; normal separation seems dominant. They suggested that the magnitude of midMesozoic deformation probably increased toward the west (into the Bisbee basin); the style of tectonism described is more akin to the rift-dominated Bisbee basin than to the Chihuahua trough pull-apart basin postulated here (Figures 2 and 3 ).

\subsubsection{Evaporite basin}

Haenggi (1966) and DeFord and Haenggi (1970) described evaporite occurrences in the Chihuahua trough and postulated a Jurassic (?) evaporite basin east of a south southeast-trending line extending from Juárez to

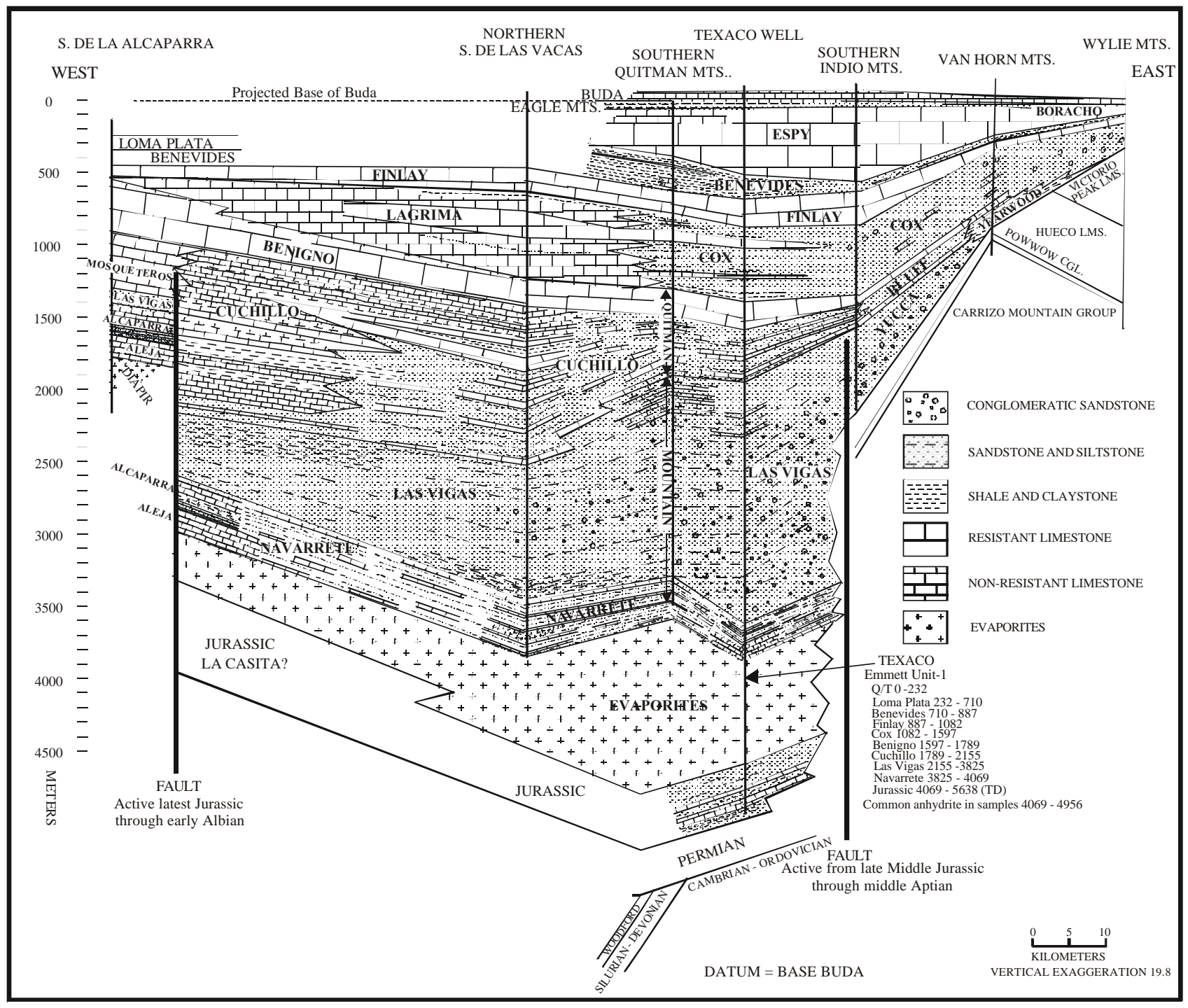

Figure 7. Lithosomal diagram of Jurassic and Lower Cretaceous formations in Sierra de la Alcaparra (Rodríguez-Torres, 1969; Córdoba, 1969), northern Sierra de las Vacas (Eaton et al., 1983), southern Quitman Mountains (Jones and Reaser, 1970), southern Indio Mountains (Underwood, 1962, 1963; Braithwaite, 1958), Van Horn Mountains (Twiss, 1959a, 1959b) and Wylie Mountains (Hay-Roe, 1958). 


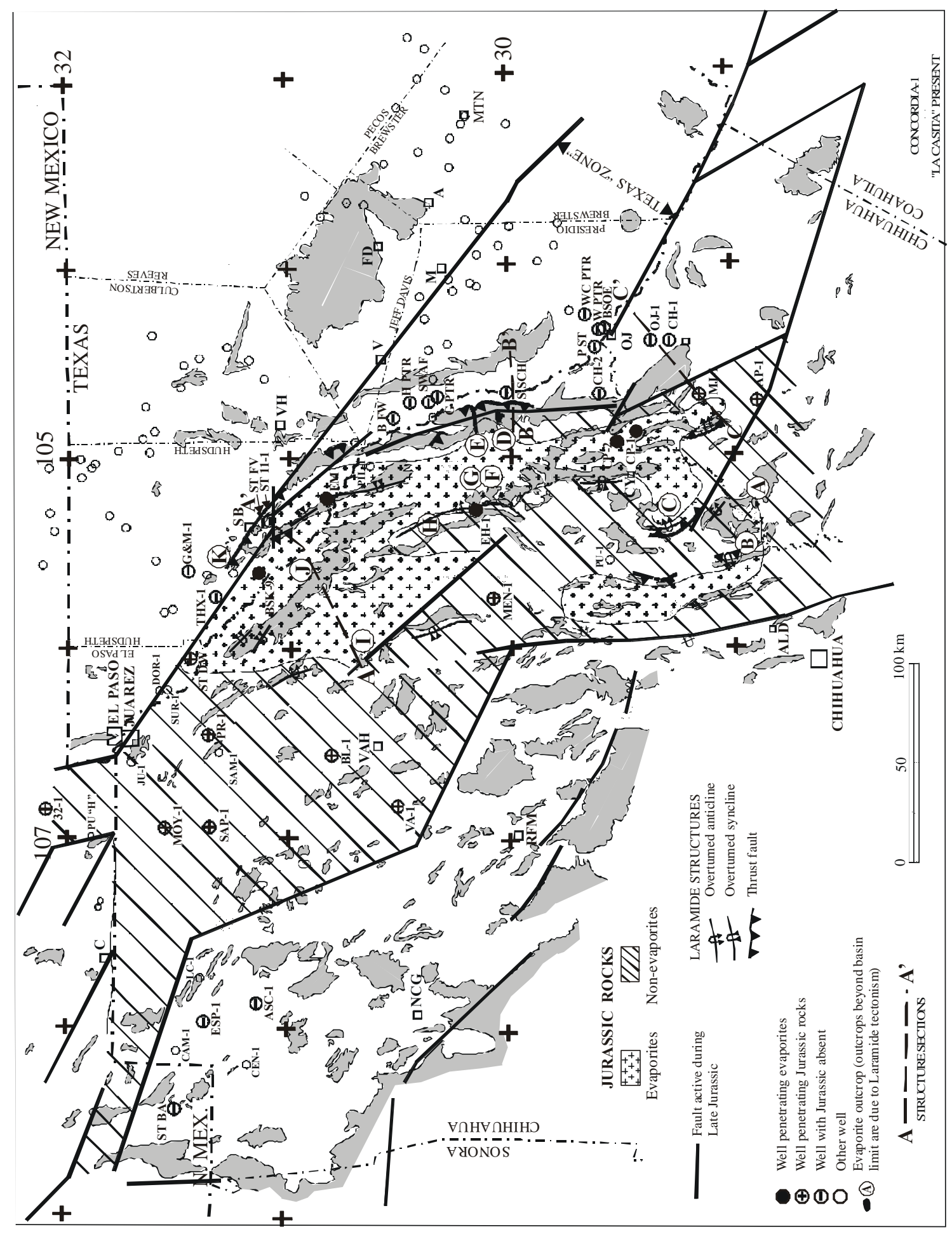

음 웡

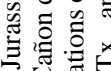

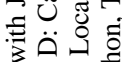

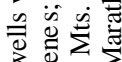

3 .

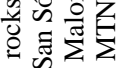

o

3 要

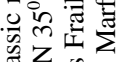

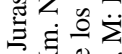

$\exists=\dot{x}$

至记

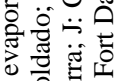

on

额

突

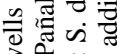

讨等

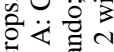

产 总氜

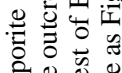

讨

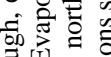

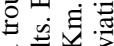

丞焉

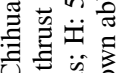

三 证

象云

웅 웅

을

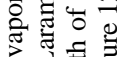

氙造

部政

尼

论

के कै

을

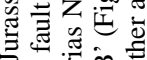

항. 훙

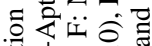

言

等焉远

政券

的数是品

究

$\infty$ 造

o

站期 
the southern boundary of the trough. From field evidence and well data, the evaporite section could be Tithonian, Neocomian or, most probably Tithonian-Neocomian. Since 1970, palynological studies have confirmed that the sections containing salt in PEMEX Cuchillo Parado1 and 2 (CP-1, CP-2) are Upper Jurassic (Tovar, J.C., personal communication in Araujo-Mendieta and CasarGonzález, 1987), one new surface outcrop area, near Cerro Pañales, south of Carrizalillo (A, Figure 8) has been described (Roberts and Dyer, 1988), three exploration wells have penetrated evaporites, and eight wells apparently did not encounter significant evaporite units in Neocomian or Jurassic sections. Figure 8 shows locations of outcrop areas and wells where evaporite rocks are reported, Table 1 includes wells that penetrated evaporite units, Table 2 lists selected wells that did not encounter Jurassic or known Neocomian rocks, and Table 3 lists outcrop areas of evaporites in Chihuahua. Food for thought on evaporite distribution is the discussion of Lucas and Lawtons (2000) on the Hell-to-Finish Formation in the Little Hatchet Mountains of New
Mexico (D, Figure 2), far from the evaporite basins described here. They described two thick ( 9 to $12 \mathrm{~m}$ ) marble beds in the Stone Cabin Gulch Member of the Hell-to-Finish Formation (basal member; possible Tithonian-Neocomian age) and interpreted the marbles, from texture and composition, as replaced former evaporite deposits.

Gypsum of the Briggs Formation in the Malone Mountains (K, Figure 8) is generally believed to be of Permian age (Albritton and Smith, 1965). The Briggs gypsum is underlain by rocks containing Permian fossils (black limestone member) and overlain by rocks containing very poorly preserved lophophylid corals (buff dolomite member). In the central and northwestern parts of the Malone Mountains there are several gypsiferous horizons in the lower part of the Jurassic Malone Formation that overlies the Briggs (Albritton and Smith, 1965). If it is in place, the Briggs Formation gypsum is Permian but regional relationships are not clear.

Three possibilities exist:

1) There are two pre-Navarrete - Las Vigas evaporite

Table 3. Chihuahua Jurassic-Neocomian evaporite localities.

\begin{tabular}{|c|c|c|c|}
\hline $\begin{array}{l}\text { Symbol in } \\
\text { Figure } 8\end{array}$ & Locality & Comment & Reference \\
\hline A & Cerro Pañales & $\begin{array}{l}\text { Gypsum between La Casita and Navarrete formations; } \\
\text { thickness not reported. }\end{array}$ & Roberts and Dyer, 1988 \\
\hline B & Sierra Soldado & $\begin{array}{l}390 \mathrm{~m} \text { of gypsum, shale and limestone below Las Vigas } \\
\text { Formation. }\end{array}$ & Humphrey, 1964. \\
\hline $\mathrm{C}$ & $\begin{array}{l}9.6 \mathrm{~km} \mathrm{~N} 35^{0} \mathrm{~W} \text { of San } \\
\text { Sóstenes }\end{array}$ & $\begin{array}{l}\text { Probable diapiric gypsum, near several igneous intrusions, } \\
\text { surrounded by outcrops of Las Vigas and La Casita } \\
\text { formations }\end{array}$ & Haenggi, 1966. \\
\hline $\mathrm{D}$ & Cañon de Navarrete & $\begin{array}{l}\text { Gypsum in contact with intrusive igneous rock, volcanic } \\
\text { rock, Navarrete, Las Vigas, Cuchillo, Benigno and Finlay } \\
\text { formations. Gypsum is diapiric, but a contact with Navarrete } \\
\text { Formation may be a normal contact. See Figure } 13 \text {. }\end{array}$ & $\begin{array}{l}\text { Haenggi, 1966; } \\
\text { De Ford and Haenggi, } 1970\end{array}$ \\
\hline $\mathrm{E}$ & Arroyo Cuatralbo & $\begin{array}{l}\text { Diapiric gypsum with Las Vigas, Cuchillo, Benigno, Cox and } \\
\text { Finlay formations. Extremely deformed Navarrete exposure } \\
\text { contains gypsum }\end{array}$ & $\begin{array}{l}\text { Haenggi, 1966, } \\
\text { De Ford and Haenggi, } 1970 .\end{array}$ \\
\hline $\mathrm{F}$ & Norias Nuevas & $\begin{array}{l}\text { Intensly folded gypsum and Navarrete Formation; gypsum, } \\
\text { containing black carbonaceous dolomite, intruded into } \\
\text { Navarrete. }\end{array}$ & $\begin{array}{l}\text { Haenggi, 1966; } \\
\text { De Ford and Haenggi, } 1970 .\end{array}$ \\
\hline G & $\begin{array}{l}5.6 \mathrm{~km} \text { north of Norias } \\
\text { Nuevas }\end{array}$ & Same as locality F. & $\begin{array}{l}\text { Haenggi, 1966; } \\
\text { De Ford and Haenggi, } 1970 .\end{array}$ \\
\hline $\mathrm{H}$ & $\begin{array}{l}5.6 \mathrm{~km} \text { Northwest of El } \\
\text { Pando, near El Pandito }\end{array}$ & $\begin{array}{l}\text { Complex folding of Las Vigas and Cuchillo formations with } \\
\text { near-vertical fold axes suggest diapiric feature. Presumably } \\
\text { involving evaporites. }\end{array}$ & $\begin{array}{l}\text { Haenggi, 1966; } \\
\text { De Ford and Haenggi, } 1970 .\end{array}$ \\
\hline I & Sierra de la Alcaparra & $\begin{array}{l}\text { Apparent diapiric gypsum (Loma Blanca Formation) in } \\
\text { eastern part of range }\end{array}$ & Rodríguez-Torres, 1969 \\
\hline $\mathrm{J}$ & Cañon de los Frailes & Gypsum intruded into Navarrete and Cuchillo formations & Haenggi, 1966 \\
\hline
\end{tabular}


sequences in the Chihuahua trough, one Permian, the other Mesozoic.

2) There is one sequence of pre-Navarrete - Las Vigas evaporites, and the gypsum of the Malones has been intruded into Permian rocks.

3) One sequence of evaporites ranges in age from the Permian to Early Cretaceous and grades into equivalent non-evaporite facies at several places in the trough.

The Chihuahua tectonic belt is the structural province formed by deformation of sedimentary rocks of the Mesozoic Chihuahua trough. Probably most of the major structures of the eastern part of the Chihuahua tectonic belt are related to movement of evaporites and décollement within the evaporite section. It seems likely that these structures, including the Malone Mountains, were influenced by only one evaporite sequence and not by two (Permian and Jurassic), located in the same stratigraphic position (above Permian and below Mesozoic rocks).

The Cerro Pañales (A, Figure 8) and Sierra Soldado (B, Figure 8) sections (see Table 3) establish the presence of probable Tithonian-Neocomian evaporites below the Navarrete Formation and above Jurassic nonevaporite rocks in the Chihuahua trough. Well data (Table 1; see Figure 8 for locations) from PEMEX El Hueso-1 (EH-1; PEMEX files, 1973, personal communication), Border Exploration Bask State-9 (BSK 9) and Texaco Emmett Unit-1 (EM) support this conclusion (data from well logs furnished by Texaco, 1998). The only evidence for Permian evaporites is from the Malone Mountains (Albritton and Smith, 1965). The entire Malone Mountains are in the hanging wall of a thrust fault that has displaced them at least $7-8 \mathrm{~km}$ from the Chihuahua trough toward the Diablo Platform. During this process it is not unreasonable to assume that Mesozoic gypsum was injected into Permian rocks along the margin of the trough.

In PEMEX El Hueso-1 (EH-1, Figure 8) the upper part of Jurassic "Unit B" is predominantly gypsum and anhydrite (PEMEX files, 1973, personal communication), Humble State University DW-1 (ST DW, Figure 8) encountered considerable gypsum in probable Jurassic rocks (Uphoff, 1978), Border Exploration Bask State 9-1 (BSK 9, Figure 8) and Texaco Emmett Unit-1 (EM, Figure 8) penetrated thick anhydrite sections within presumed Jurassic sections (data from well logs provided by Texaco, 1998). Evaporites are apparently not present in many wells that penetrated Jurassic rocks (Table 2). PEMEX wells (see Figure 8 for locations) that penetrated Jurassic rocks but did not encounter significant evaporites are Moyotes-1 and Provincia-1 (MOY-1, PR-1; PEMEX files, 1973, personal communication), Sapallo-1 (SAP-1; Thompson et al., 1978), Menonita-1 (MEN-1; Dyer, 1987), and Apache-1 and Maijoma-1 (AP-1, MJ-1; Cantú-Chapa et al., 1985; LimónGonzález, 1986; López-Ramos, 1988). Grimm and Hunt Mobil “32”-1 (32-1, Figure 8) in Doña Ana County New Mexico (Thompson and Bieberman, 1975; Uphoff,
1978) encountered a Jurassic section that does not contain evaporites.

All data from the previous discussion have been incorporated into the delineation of postulated evaporite basins (Figure 8). Boundaries of the basins are based on structural style as well as data. Strongly overturned folds and thrust faults are assumed to occur near the margins of evaporite deposits and their distribution is integrated into the interpretation.

\subsection{Middle Neocomian - early Aptian}

Following the latest Jurassic-earliest Cretaceous "regressive" event there was a long period (late Valanginian-early Aptian?) of equilibrium between basin subsidence and sedimentation. This was the time of deposition of the Las Vigas Formation, the largest (by volume) stratigraphic unit in the Chihuahua trough. Sedimentary features of the Las Vigas are interpreted as indicators of fluvial, lacustrine, lagoonal and bay environments (Campbell, 1970; his Mountain facies of Yucca Formation). Haenggi (1966) suggested that most of the Las Vigas was deposited in a sea and used the term "juxtamarine" to indicate the fluctuating near-shore marine and terrestrial environment of deposition. In the eastern part of the Chihuahua trough studies of paleocurrents indicate prevalent directions parallel to the Diablo Platform (Haenggi, 1966; Campbell, 1970).

\subsubsection{Las Vigas lithosome}

Haenggi (1966) described the Las Vigas lithosome in the Chihuahua trough and adjacent Trans-Pecos Texas and defined it as the Las Vigas Formation, and equivalent parts of the Yucca and Mountain formations (Figures 7 and 9 and Table 4). He estimated the volume of the lithosome as $21,000 \mathrm{~km}^{3}$. On Figure 9 and in Table 4 definition of the Las Vigas lithosome is expanded to include part of the Hell-to-Finish Formation of southwestern New Mexico and northwestern Chihuahua; the lithosome certainly includes part of the Morita Formation of the Arizona portion of the Bisbee basin. The southern limit of the Las Vigas lithosome is not known but there are indications that it intertongues with Neocomian-Aptian formations of the Mar Mexicano (López-Ramos, 1988; see description PEMEX Apache-1 in Table 3).

The Yucca Formation of the Indio Mountains (L, Figure 9; Underwood, 1962, 1963) and the southern Van Horn Mountains (M, Figure 9; Twiss, 1959a, 1959b) is included in the Las Vigas lithosome. The Yucca in these ranges is in the hanging walls of mapped thrust faults (Twiss, 1959a, 1959b; Underwood, 1962, 1963) and is displaced an unknown distance toward the east from original sites of deposition. Interpretation of paleogeology shown by Figures 2 and 8, suggests a minimum displacement of $15 \mathrm{~km}$ from original depositional sites, within the Chihuahua trough, to the outcrops of Yucca 


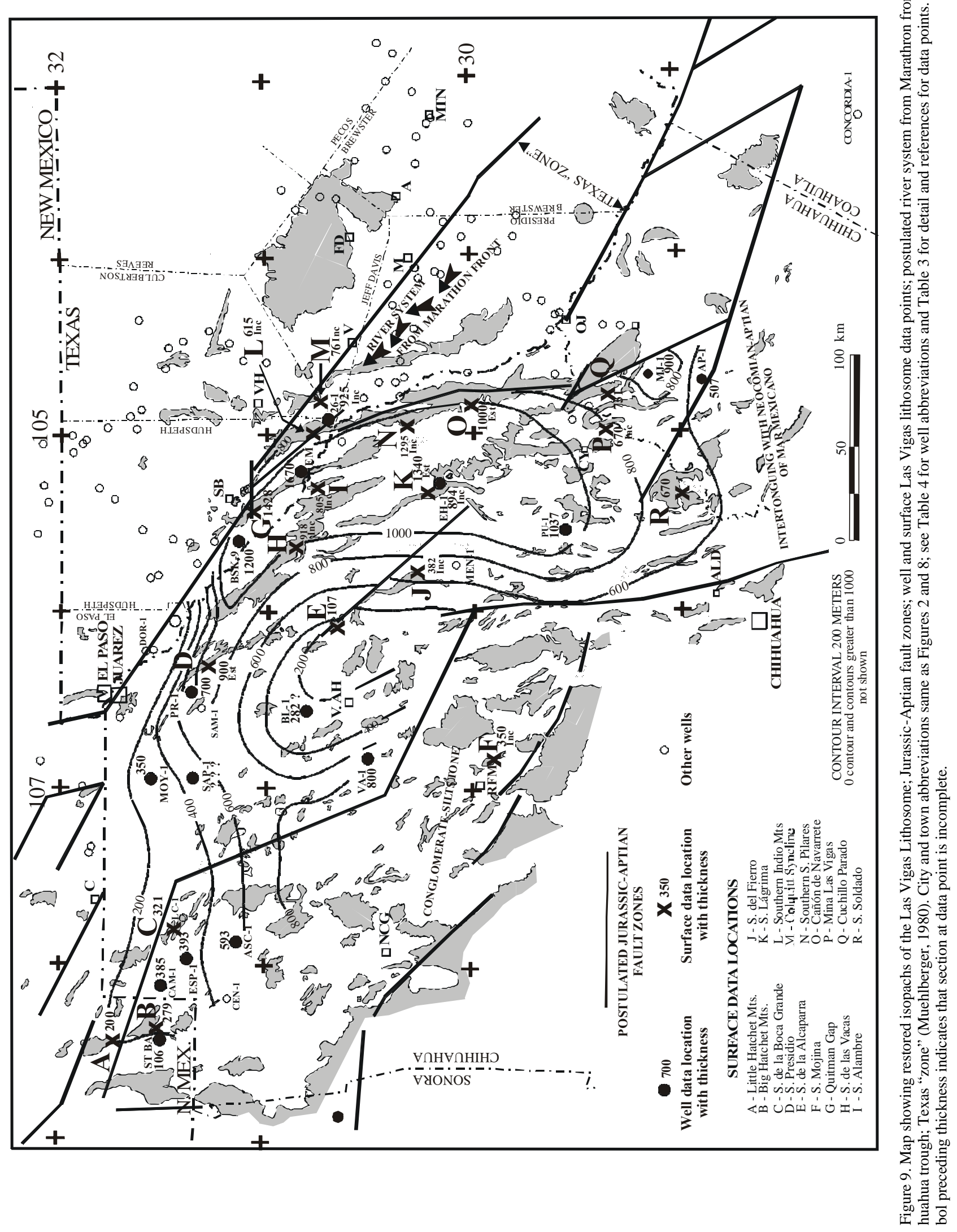


Table 4. Las Vigas lithosome. Data used to construct Figure 9.

\begin{tabular}{|c|c|c|c|}
\hline $\begin{array}{l}\text { Well Section } \\
\text { (map symbol) }\end{array}$ & $\begin{array}{l}\text { Thickness } \\
\text { (m) }\end{array}$ & Comment & Data Source \\
\hline $\begin{array}{l}\text { Little Hatchet Mountains } \\
\text { (A) }\end{array}$ & 200 & $\begin{array}{l}\text { Lower } 200 \mathrm{~m} \text { Winkler Ranch Member Hell-to-Finish } \\
\text { Formation. }\end{array}$ & Lucas and Lawton, 2000. \\
\hline $\begin{array}{l}\text { Big Hatchet Mountains } \\
\text { (B) }\end{array}$ & 279 & Upper 279 m Hell-to-Finish Formation type section. & Zeller, 1965. \\
\hline $\begin{array}{l}\text { Humble No. } 1 \text { State "BA" } \\
\text { (ST BA) }\end{array}$ & 106 & Hell-to-Finish Formation & Zeller, 1965. \\
\hline $\begin{array}{l}\text { Sierra de la Boca Grande } \\
\text { (C) }\end{array}$ & 321 & Las Vigas Formation; same unit present in S. Rica. & Ramírez -M. and Acevedo-C., 1957. \\
\hline $\begin{array}{l}\text { PEMEX Camello-1 } \\
\quad(\text { CAM-1) }\end{array}$ & 385 & Hell-to-Finish Formation. & Thompson et al., 1978 \\
\hline $\begin{array}{l}\text { PEMEX Espía-1 } \\
\quad(\text { ESP-1) }\end{array}$ & 393 & Hell-to-Finish Formation. & $\begin{array}{l}\text { PEMEX files, 1973; } \\
\text { Thompson et al., } 1978 .\end{array}$ \\
\hline $\begin{array}{l}\text { PEMEX Asensión-1 } \\
\text { (ASC-1) }\end{array}$ & 593 & Metamorphosed Hell-to-Finish Formation. & Thompson et al., 1978 \\
\hline $\begin{array}{l}\text { PEMEX Moyotes-1 } \\
\text { (MOY-1) }\end{array}$ & 350 & Las Vigas Formation. & $\begin{array}{l}\text { PEMEX files, 1973; } \\
\text { Thompson et al., } 1978 .\end{array}$ \\
\hline $\begin{array}{l}\text { PEMEX Sapallo-1 } \\
\quad(\text { SAP-1) }\end{array}$ & $? ? ?$ & $\begin{array}{l}\text { 3,686 m Lower Cretaceous; } \\
\text { Las Vigas must be present. }\end{array}$ & Thompson et al., 1978. \\
\hline $\begin{array}{l}\text { Sierra Presidio } \\
\text { (D) }\end{array}$ & 900 & Estimate from stratigraphic section. & Webb, 1969 \\
\hline $\begin{array}{l}\text { PEMEX Presidio-1 } \\
\text { (PR-1) }\end{array}$ & $>700$ & Incomplete 790-meter section Las Vigas-Navarrete. & PEMEX files, 1973. \\
\hline $\begin{array}{l}\text { Sierra de la Alcaparra } \\
\text { (E) }\end{array}$ & 107 & Las Vigas Formation. & Rodríguez-Torres, 1969 \\
\hline $\begin{array}{l}\text { Sierra Mojina } \\
\text { (F) }\end{array}$ & $>350$ & $\begin{array}{l}\text { Siltstone and conglomerate below "Cupido"; } \\
\text { base not exposed. }\end{array}$ & $\begin{array}{l}\text { Ramírez-M. and Acevedo-C., 1957; } \\
\text { Bridges, 1964b; PEMEX, } 1984 \text { field } \\
\text { trip. }\end{array}$ \\
\hline $\begin{array}{l}\text { PEMEX Banco Lucero-1 } \\
\text { (BL-1) }\end{array}$ & 282 & $\begin{array}{l}\text { Las Vigas Formation, less limestone at base, } \\
\text { on cross section. }\end{array}$ & López-Ramos, 1988 \\
\hline $\begin{array}{l}\text { PEMEX Villa Ahumada-1 } \\
\text { (VA-1) }\end{array}$ & 800 & Las Vigas Formation, "different facies". & PEMEX files, 1973. \\
\hline $\begin{array}{l}\text { Border Ex. BASK STATE 9-1 } \\
\text { (BSK-9) }\end{array}$ & 1,200 & Well logs; corrected for $25^{\circ}$ dip $(1,326 \mathrm{~m}$ penetrated). & $\begin{array}{l}\text { Texaco, } 1998 \text { personal } \\
\text { communication }\end{array}$ \\
\hline $\begin{array}{l}\text { Quitman Gap } \\
\text { (G) }\end{array}$ & 1,428 & Middle and Upper Yucca Formation. & Campbell, 1980. \\
\hline $\begin{array}{l}\text { Sierra de las Vacas } \\
(\mathrm{H})\end{array}$ & $>918$ & $\begin{array}{l}\text { Las Vigas Formation believed incomplete } \\
\text { due faulting. }\end{array}$ & Eaton et al., 1983. \\
\hline $\begin{array}{l}\text { Sierra Alambre } \\
\text { (I) }\end{array}$ & $>805$ & Upper 805 m of Las Vigas Fm., top not exposed. & Milton, 1964. \\
\hline $\begin{array}{l}\text { Texaco Emmett-1 } \\
\text { (EM) }\end{array}$ & 1,670 & From well logs. & $\begin{array}{l}\text { Texaco, } 1998 \text { personal } \\
\text { communication. }\end{array}$ \\
\hline$\underset{(\mathrm{J})}{\text { Sierra del Fierro }}$ & $>382$ & Las Vigas Formation; base not exposed. & Ramírez-M. and Acevedo-C., 1957. \\
\hline $\begin{array}{l}\text { Sierra Lágrima } \\
(\mathrm{K})\end{array}$ & 1,340 & Las Vigas Formation, estimated thickness. & Haenggi, 1966. \\
\hline $\begin{array}{l}\text { PEMEX El Hueso-1 } \\
\text { (EH-1) }\end{array}$ & $>894$ & Las Vigas Formation at surface. & PEMEX files, 1973 \\
\hline
\end{tabular}


Table 4. Continued.

\begin{tabular}{|c|c|c|c|}
\hline $\begin{array}{l}\text { Well Section } \\
\text { (map symbol) }\end{array}$ & $\begin{array}{l}\text { Thickness } \\
\text { (m) }\end{array}$ & Comment & Data Source \\
\hline $\begin{array}{l}\text { Southern Indio Mountains } \\
\text { (L) }\end{array}$ & $>615$ & $\begin{array}{l}\text { Yucca Formation, base not exposed, east of Indio } \\
\text { fault (Jurassic basin boundary). }\end{array}$ & Underwood, 1962 \\
\hline $\begin{array}{l}\text { Colquitt syncline } \\
\text { (M) }\end{array}$ & $>76$ & Yucca Formation, base not exposed. & Twiss, $1959 b$ \\
\hline $\begin{array}{l}\text { Southern Sierra Pilares } \\
\text { (N) }\end{array}$ & $>1,295$ & $\begin{array}{l}\text { Las Vigas Formation, above Pilares thrust fault, } \\
\text { base not exposed. }\end{array}$ & Yeager, 1960 \\
\hline $\begin{array}{l}\text { Cañon de Navarrete } \\
(\mathrm{O})\end{array}$ & 1,000 & Las Vigas Formation; estimated thickness. & Haenggi, 1966. \\
\hline $\begin{array}{l}\text { Mina Las Vigas } \\
\text { (P) }\end{array}$ & $>670$ & $\begin{array}{l}\text { Las Vigas Formation type section; } \\
\text { estimated thickness, base not exposed. }\end{array}$ & Burrows, 1909. \\
\hline $\begin{array}{l}\text { Cuchillo Parado } \\
\text { (Q) }\end{array}$ & 731 & Las Vigas Formation. & Peebles, 1991 \\
\hline $\begin{array}{l}\text { Sierra Soldado } \\
\text { (R) }\end{array}$ & 670 & Las Vigas Formation & Humphrey, 1964. \\
\hline $\begin{array}{l}\text { PEMEX Maijoma-1 } \\
\text { (MJ-1) }\end{array}$ & $>900$ & $\begin{array}{l}\text { Las Vigas Formation immediately below thrust that } \\
\text { repeats formation; } 900 \text { meters in hanging wall. } \\
\text { Thickness from stratigraphic section. }\end{array}$ & López-Ramos, 1988 \\
\hline $\begin{array}{l}\text { PEMEX Apache-1 } \\
\text { (AP-1) }\end{array}$ & 507 & $\begin{array}{l}\text { Las Vigas Formation plus } 213 \text { meters "Las Vigas" } \\
\text { within Navarrete Formation. Thickness from } \\
\text { stratigraphic section. }\end{array}$ & López-Ramos, 1988 \\
\hline
\end{tabular}

on the west flank of the Colquitt syncline in the southern Van Horn Mountains (M, Figure 9). This apparent $15-\mathrm{km}$ displacement is much greater than typical thrust displacements in the trough and can be interpreted differently. In this area the Las Vigas lithosome contains abundant detrital chert (atypical of the lithosome) that may be derived from exposures of Paleozoic rocks in the Marathon Mountains to the southeast; a major river system from the Marathons (Figure 9) may have formed a delta where it entered the Chihuahua trough in the Colquitt syncline - southern Indio Mountains area. Hence, the lithosome in vicinity of the Colquitt syncline is at or near its original depositional site.

The Yucca Formation of Bluff Mesa and Yucca Mesa (type locality of Taff, 1891), at the northwest end of Devil Ridge (Figure 1), and the Yucca Formation mapped by Amsbury $(1957,1958)$ in the Pinto Canyon area, immediately north of the Chinati Mountains (Figure 1 and Figure 5), are not part of the Las Vigas lithosome because the formation contains abundant limestone and limestone clasts in conglomerates (more than 30 percent) at these localities (Amsbury, 1958; Albritton and Smith, 1965); limestone and limestone clasts are virtually absent in the Las Vigas Formation.

In the Chihuahua trough, the Las Vigas lithosome is asymmetrical, thickening abruptly adjacent to the Diablo Platform thence thinning gradually toward the Aldama platform (Figures 6 and 9). Conglomeratic sandstone is common near the eastern edge of the trough and is virtually absent in the central part of the trough, e.g., in Sierra del Soldado (R, Figure 9; Humphrey, 1964), Sierra del Fierro (J, Figure 9; Ramírez-M. and Acevedo-C., 1957) and Sierra Lágrima (K, Figure 9; Haenggi, 1966).

All exposed and drilled sections of the Las Vigas lithosome along the margin of the Diablo Platform have been displaced some distance toward the east from original depositional sites within the Chihuahua trough. Displacements vary but range from several kilometers to perhaps $15 \mathrm{~km}$ or more. Palinspastic restoration of the sections indicates that the boundary of the Las Vigas lithosome and the Diablo Platform was abrupt in Early Cretaceous time (Figure 9 incorporates palinspastic restoration). This leads to the interpretation that, during deposition of the Las Vigas lithosome, there was active faulting along the Platform margin involving the same fault system that created the Late Jurassic basin (Figures 6, 7 and 9).

Relationships of the Las Vigas lithosome to the Aldama platform are not clear but there are indications that erosion of a metamorphic terrane, exposed on the platform, contributed to a pre-Albian? conglomeratic unit that occupies the stratigraphic position of the Las Vigas Formation and/or the Glance Conglomerate north of Sierra del Nido (Figure 1). The apparent presence of a pre-Albian conglomeratic unit on this portion of the 
Jurassic Aldama platform is the basis for inclusion of this area in the Chihuahua trough. With the possible exception of rocks exposed in Sierra Magistal, $60 \mathrm{~km}$ south-southwest of Cd. Chihuahua (not shown by Figure 9), the closest outcrops of Las Vigas to the Jurassic Aldama platform (Figure 2) are in Sierra Soldado (R, Figure 9) and Sierra del Fierro (J, Figure 9) about $60 \mathrm{~km}$ east of the platform boundary.

At Sierra Mojina (F, Figure 9; $15 \mathrm{~km}$ southeast of R.F. Magón), located on the northern part of the Jurassic Aldama platform and at the northern edge of the Aptian Aldama platform, Bridges (1964b) described a cobble and boulder conglomerate (maximum thickness $150 \mathrm{~m}$ ) composed predominantly of metamorphic rock clasts (quartzite, "gneissic" quartzite and schist) with minor limestone and vein quartz. The conglomerate is underlain by siltstone, therefore is not a basal conglomerate and grades laterally into siltstone; maximum thickness of conglomerate and siltstone is about $350 \mathrm{~m}$. This section is not typical of the Las Vigas lithosome but may be similar to a section encountered in PEMEX Villa Ahumada-1 (VA-1, Figure 9) located $65 \mathrm{~km}$ north of the Sierra Mojina. PEMEX Villa Ahumada-1 penetrated $800 \mathrm{~m}$ of "Las Vigas" but PEMEX files note that this is "a different facies, sandstone with intraformational conglomerates" (PEMEX files, 1973, personal communication). It is possible that this section is contiguous with the Sierra Mojina section and both have a different provenance (Aldama platform?) than the bulk of the Las Vigas lithosome. From gravimetric data PEMEX suggests the presence of an island (Isla de Villa Ahumada) in the area of the Villa Ahumada well (PEMEX, personal communication, 2000).

At Sierra del Cuervo (Figure 1), on the eastern edges of the Jurassic and Cretaceous Aldama platform, Ramírez-M. and Acevedo-C. (1957) described a thin (maximum thickness about $90 \mathrm{~m}$ ) basal Mesozoic conglomeratic reddish sandstone unit that locally contains gypsum and is overlain by a thin $(15 \mathrm{~m})$ ammonite-bearing (Dufrenoya) interbedded limestonesandstone-shale unit (Cuchillo Formation). Handschy (1984) mapped the basal conglomeratic unit at Sierra del Cuervo as Las Vigas. Ramírez-M. and Acevedo-C. (1957) called it Cuchillo with the caveat that a more detailed study might establish the presence of Las Vigas in the section. The Sierra del Cuervo basal conglomerate unconformably overlies the Permian Rara Formation indicating that it was deposited on an area that was emergent during Jurassic, Neocomian and much of Aptian time (Aldama platform). At all places where the base of the Las Vigas is observed in the Chihuahua trough, it is underlain by Neocomian and/or Jurassic units indicating deposition in a subsiding Early Cretaceous basin. The conglomerate may be coeval with a part of the lithosome, but is probably not contiguous with parts of the Las Vigas lithosome. It is not considered here as part of the Las Vigas because its depositional setting is different than that of the lithosome.
Sixty kilometers south-southwest of Cd. Chihuahua, in Sierra Magistral (not shown by Figures 1 and 9), more than $500 \mathrm{~m}$ of well-cemented sandstone (base not exposed) underlies Albian limestone (Bridges, 1964b). Ramírez-M. and Acevedo-C. (1957) called this unit Travis Peak but noted, in their discussion of the Las Vigas Formation, that the lower part of the section might be Las Vigas.

The volume of the Las Vigas lithosome and its composition suggest a major source area(s) composed principally of metamorphic and sedimentary rocks. Conglomeratic sandstones and pebble conglomerate are common in the lower part of the Las Vigas lithosome along the boundary of the Chihuahua trough and Diablo Platform and are especially well developed in the Indio Mountains (L, Figure 9; Yucca Formation) where conglomeratic units are the dominant lithology of the lower half of a 615-m incomplete section (base not exposed) measured by Underwood $(1962,1963)$. Abundant varicolored chert in the Indio Mountain conglomerates and the Yucca Formation penetrated by Border Exploration State "26-1" (26-1, Figure 9) suggest a source to the southeast from exposed rocks of the Marathon orogenic belt. The rather limited distribution of conglomerates and conglomeratic sandstones in the Las Vigas lithosome suggest that erosion of positive areas directly adjacent to the east and north of the Chihuahua trough did not contribute significant amounts of sediment to the lithosome. Conglomeratic units adjacent to the Aldama platform are probably coeval with the Las Vigas lithosome and are included in it (Figure 9).

Where did these sediments come from?; a source area of continental proportions was necessary to provide material for the Las Vigas. Petrographic studies of the Morita Formation of the Arizona portion of the Bisbee basin indicate that it is composed of siliceous rocks derived from a cratonic platform to the north and deposited in a large deltaic complex (Jamison, 1987). The Las Vigas of the Chihuahua trough can be interpreted in a similar manner. DeFord suggested (1965, personal communication) that during the Late Jurassic and the Neocomian the Wichita paleoplain (Hill, 1901) was covered with terrigenous sediment derived from itself, the Ouachita tectonic belt and other features. This implies that the Wichita paleoplain, a degradational feature, was preceeded by formation of a constructional plain built of post-orogenic sediment derived from the Ouachita fold belt and the ancestral Rocky Mountains; today most of the sediment is gone, but the peneplain remains. The Triassic Dockum Group is a remnant of the constructional plain. Some time during the early Mesozoic (Jurassic?), the destructional development of the Wichita paleoplain began and some of the material removed from it by river systems was eventually deposited into the arms of transgressing seas; e.g., the Chihuahua trough.

There is speculative evidence for active faulting within the Chihuahua trough during the time of deposition of the Las Vigas lithosome. In Sierra de la Alcaparra 
(E, Figure 9) the Las Vigas is $107 \mathrm{~m}$ thick (RodríguezTorres, 1969; see Figure 9 and Table 4). This is the thinnest complete section of definite Las Vigas reported in the Chihuahua trough. The Sierra de la Alcaparra section is an order of magnitude thinner than an incomplete 956-m Las Vigas section reported in Sierra de las Vacas about $55 \mathrm{~km}$ to the northeast (H, Figure 9; Eaton et al., 1983) and considerably less than an incomplete 382-m section in Sierra del Fierro about $45 \mathrm{~km}$ to the southsoutheast (J, Figure 9; Ramírez-M. and Acevedo-C., 1957). There are no Las Vigas outcrops west of Sierra de la Alcaparra, but PEMEX Banco Lucero-1 (BL-1), located $45 \mathrm{~km}$ to the west-northwest, penetrated $416 \mathrm{~m}$ of Las Vigas according to a stratigraphic cross section shown by López-Ramos (1988). $282 \mathrm{~m}$ of this section is included in the Las Vigas lithosome (Figure 9; Table 4). The differences of stratigraphy in Sierra de la Alcaparra and the sections to the east and west are interpreted to be the result of continuing intra-basin faulting during and subsequent to deposition of the Las Vigas (AptianAlbian); perhaps local "islands" were developed. This faulting is most likely along a north-trending continuation of the Jurassic fault system forming the eastern margin of the Aldama platform (see Figures 2 and 7). The Albian component of faulting is inferred from changes in lithology and thickness of the Cuchillo, Benigno and Lágrima formations that occur somewhere east of Sierra de la Alcaparra and from facies changes of the Benigno, Lágrima, Finlay and Benevides that are observed in Sierra Banco de Lucero, $60 \mathrm{~km}$ west of Sierra de la Alcaparra (Guerrero, 1969; Córdoba, 1969). This postulated faulting can be assailed by arguments favoring a two-sided basin with differing sources for clastic sediments during Neocomian and Aptian time and changes in depositional environments during Albian time.

\subsection{Middle Aptian - early Albian}

The Las Vigas grades upward into the Cuchillo Formation which records definite marine transgression into the Chihuahua trough during late Aptian and early Albian time. To the northwest, in the Bisbee basin, carbonate platform deposition was prevalent after transgression (Mural Limestone). In the Chihuahua trough, local evaporite basins developed during initial stages of transgression; e.g., the lower part of the type section of the Cuchillo Formation at Cuchillo Parado (Figure 1) contains extensive gypsum beds and in Sierra Presidio (Figure 1) Webb (1969) reported thick beds of sedimentary gypsum in a 305-m Aptian-Albian unit that he assigned to the Cuchillo Formation. The Cuchillo Formation contains the most diverse facies changes of any stratigraphic unit in the Chihuahua trough. Formation names that have been applied to these facies in the trough are Travis Peak and Glen Rose (Ramírez-M., and Acevedo-C., 1957); Coyame, La Peña, La Virgen
(Cantú-Chapa et al., 1985); Mosqueteros (RodríguezTorres, 1969); Quitman (Taff, 1891), Bluff (Haenggi, 1966), and, in PEMEX Pulpito-1 (PU-1, Figure 9), Coyame, La Peña, Cupido and La Virgen (PEMEX, 2000, personal communication). The Cuchillo contains varying amounts of shale, thin- to thick-bedded limestone, and sandstone and locally gypsum. Deposition over most of the trough was in platform and littoral environments with local development of sabkhas. In the area of Sierra de la Alcaparra and Sierra de Mosqueteros (Figure 1) the facies changes to a "deep water platform environment" called the Mosqueteros Formation (Córdoba et al., 1970). Generally the Cuchillo is a nonresistant and incompetent unit that is faulted and disharmonically folded at many places; hence accurate measurements of thickness are difficult to make. There is considerable variation in thickness from place to place; e.g., in the vicinity of Cuchillo Parado the thickness varies from 610 to 370 m (Ramírez-M., and Acevedo-C., 1957). The Cuchillo contains abundant fossils; ammonite zonation places the Aptian-Albian boundary within the formation. Sometime during latest Aptian time active faulting along the margin of the Diablo Platform ceased and the seas transgressed onto the Platform.

There is an indication of intrusive igneous activity in the Chihuahua trough during deposition of the Cuchillo Formation. After drilling through 1,681 m of Jurassic rocks. PEMEX El Hueso-1 (EH-1, Figure 9) encountered $301 \mathrm{~m}$ of porphyritic rhyolite from $4,617 \mathrm{~m}$ to a total depth of 4,918 m (PEMEX files, 1973, personal communication). This rhyolite was dated at $110 \pm 10 \mathrm{Ma}$ (Albian using time scale of Gradstein et al. 1994) by Tim Denison who believed it was originally extrusive.

\subsection{Middle and late Albian - early Cenomanian}

By middle Albian time seas had advanced onto cratonal North America in Texas and covered previously emergent areas adjacent to the Chihuahua trough in Mexico and Texas. Along the western margin and in the central part of the trough, carbonate platform deposits were being deposited (Benigno and Lágrima formations). At the same time, from the general area of Sierra Blanca, Texas southward to the Rio Conchos, deposits of the Cox Formation extended into the Chihuahua trough from Texas. The Cox is predominantly sandstone and occurs in the Quitman Mountains, Sierra Cieneguilla, Sierra Pilares, Sierra Pinosa and Sierra de la Parra (see Figure 1 for locations). In Sierra de la Parra, the Cox Formation grades from a predominant sandstone unit in the eastern part of the range to a predominant carbonate unit to the west (Lágrima Formation). The lateral facies change to the carbonate occurs abruptly near the western edge of this range (Haenggi, 1966). The Cox is recognized over a large part of Trans-Pecos Texas from Pinto Canyon in the south (immediately north of Chinati Mountains and east of Sierra Pinosa and Sierra de la 
Parra) north to several localities on the Diablo Plateau (Miller, 1975) and has been mapped as far east as $40 \mathrm{~km}$ west of Pecos, Texas on the Pecos Sheet of the Geologic Atlas of Texas (Barnes and Eifler, 1976). At many localities in Trans-Pecos Texas it constitutes the basal unit of the Cretaceous System. The outcrop area and extent of the Cox Fm. suggest that it was deposited in a delta along the eastern edge of the Chihuahua trough and the apex of the delta is in the vicinity of Sierra Blanca, Texas (Figure 1). Miller (1975) suggested an eastern source for the Cox and interpreted it as a "multiple cycle" deposit derived from sedimentary sources (mature, reworked from distant sources). The Cox can be interpreted as part of the basal sand sequences that reflect the Cretaceous transgression in Texas (e.g., Antlers Sand). Interpretation of the Cox as part of a transgressional sequence, forming as the seas advanced onto the North American craton, precludes any explanation that relates it to tectonic events unique to the Chihuahua trough.

Except for two periods of terrigenous deposition in late Albian and early Cenomanian time (Benevides and Del Rio/Eagle Mountains formations), shallow water carbonate deposition was predominant in the Chihuahua trough from latest early Albian through middle Cenomanian time. The two periods of terrigenous deposition are recognized over vast areas of Texas (Kiamichi Formation, Grayson/Del Rio formations) and are not indicative of tectonism specific to the Chihuahua trough.

\subsection{Middle Cenomanian - Senonian}

The contact between the Buda Limestone and Ojinaga Fm. (Comanche-Gulf series boundary) records an extreme change in depositional environment from shallow water carbonate to marine terrigenous deposition. In many areas of Trans-Pecos Texas this contact is reported as disconformable (Adkins, 1933, Twiss, 1959a, Maxwell and Dietrich, 1965). Many authors reported that there is no physical evidence to support a disconformity between the Buda and overlying Cretaceous formations (e.g., see Ramírez-M. and Acevedo-C., 1957; Underwood, 1962; and Haenggi, 1966).

The Ojinaga Formation, a thick unit $(600+$ meters $)$ consisting of marine shale with minor sandstone and limestone interbeds, records a sudden influx of clastic material into the Chihuahua trough. The CenomanianSantonian? Ojinaga Formation is coeval with Upper Cretaceous formations comprising a series of clastic wedges in the Western Interior Cretaceous Seaway of the United States and Canada. Thus, the clastic influx into the Chihuahua trough represented by the Ojinaga Formation seems to be related to growth of the Cordillera during the last stages of the Sevier orogenic time slice (84-168 Ma) of the Tectonic Map of North America (Muehlberger, 1992).

In the Rim Rock country of Texas (Sierra Vieja,
Figure 1) and in structurally low areas around Ojinaga (Figure 1), the only areas where post-Ojinaga Cretaceous rocks are reported, the Ojinaga grades upward into the San Carlos Formation that is, in turn, conformably overlain by El Picacho Formation. The San Carlos is a sandstone unit that records the transition from marine to non-marine deposition in the trough. Wolleben (1966) has dated the marine part of the formation as early Campanian (Senonian). Wood fragments, dinosaur bones and coal beds in the upper part of the formation demonstrate the change to non-marine deposition. The El Picacho Formation, a non-marine claystone-sandstone unit containing lignite beds, is the youngest preserved Cretaceous formation in the Chihuahua trough.

During Cenomanian-Senonian time igneous activity and metamorphism affected parts of the Chihuahua trough. Denison et al. (1970) reported nine metamorphic mica K-Ar dates from outcrops and wells in the Sierra Samalayuca (Figure 1). Their dates range from 92.5 Ma to $77.7 \mathrm{Ma}$ and Denison et al. (1970) considered the younger ages (78-84 Ma) as the most reliable for dating metamorphism. Using the time scale of Gradstein et al. (1994) this low-grade metamorphic event is dated as latest Santonian-Campanian (Senonian). McDowell and Maugher (1994) reported relatively minor igneous activity during latest Cretaceous and Paleocene time from several localities extending about $45 \mathrm{~km}$ northward from $\mathrm{Cd}$. Chihuahua. U-Pb dates in the area range from 55 to $68 \mathrm{Ma}$, and the $68 \mathrm{Ma}$ Maestrichtian date (only Cretaceous date) is from a sample that is stratigraphically high in a thick (estimated $3 \mathrm{~km}$ ) sequence interpreted as part of a stratovolcano complex composed of intermediate composition lavas, mudflow breccias, coarse clastic units and minor felsic tuffs: the Peñas Azules Volcanics. Gilmer (2001), reported Cretaceous dates (64.2 $\pm 0.2 \mathrm{Ma}$ $\mathrm{U}-\mathrm{Pb}$ and $60.2 \pm 0.3 \mathrm{Ma} \mathrm{Re}-\mathrm{Os}$ ) from the Red Hills porphyry Copper - molybdenum deposit in the Chinati Mountains (see Figure 1 for location) east of the Chihuahua trough in Trans Pecos Texas.

\section{The Laramide Orogeny}

During the Laramide orogeny the Chihuahua trough was inverted to form the Chihuahua tectonic belt (DeFord, 1958a). Laramide is used here in the same time sense (ca. $84 \mathrm{Ma}$ to $c a .43 \mathrm{Ma}$ ) as that of the Tectonic Map of North America (Muehlberger, 1996).

Studies in the southwestern United States and adjacent Mexico indicate that Mesozoic tectonism advanced from the west toward the east as the North American plate overrode the Farallon plate; the general direction of the advance of the North American plate was toward the southwest (Burchfiel and Davis, 1975; Coney, 1976). Drewes (1991a) described the Cordilleran orogeny becoming progressively younger from west to east (late Jurassic to Eocene; includes Sevier and Laramide time slices of the Tectonic Map of North America) and placed deformation in northern Chihuahua in the Eocene. In a 
similar fashion, Keith and Wilt (1986) described four phases of Laramide orogeny (becoming younger toward the east) and placed events in New Mexico, directly north of the Chihuahua trough, in their culminant phase (45-55 Ma). In southeastern Arizona, Davis (1979) advocated two pulses of Laramide tectonism: 1) early late Cretaceous consisting of tight folding and high-angle faulting along narrow west-northwest-trending deformation belts, and 2) latest Cretaceous/early Tertiary folding and reverse faulting associated with a large westnorthwest-trending basement-cored uplift. There is no evidence in the Chihuahua tectonic belt to confirm or deny progressive west to east deformation but there is a suggestion, in the sedimentary history of the Tornillo basin (a Laramide foreland basin along the eastern edge of the Chihuahua trough), that two pulses of Laramide tectonism were involved in the formation of the Chihuahua tectonic belt (Lehman, 1991). Lehman interpreted two major phases of tectonism in source areas of sediments of the Tornillo Basin: 1) middle to late Maestrichtian (ca. $70 \mathrm{Ma}$ ) and 2) Paleocene (ca.61 Ma). This is in general agreement with two-phase hypotheses of Laramide tectonism presented by several authors (e.g., Cather and Chapin, 1990).

In the Chihuahua trough latest Laramide deformation, during Eocene time, is documented by studies of intrusions and volcanic rocks along the northtrending boundary between the southern part of the trough and the Aldama platform. In Sierra Peñas Blancas (Figure 1), about $60 \mathrm{~km}$ north of Cd. Chihuahua, Reyes-Cortés and Goodell (2000) reported K-Ar dating of "folded" (Cuervo Formation) and "unfolded" (Nopal Formation) volcanic rocks that indicate deformation between 44 and 54 Ma. From an area of central Chihuahua, between Latitude $28^{\circ} 00^{\prime}$ and 30'00', along Longitude 106 30', McDowell and Maugher (1994) described tilted rocks consisting of a $68 \mathrm{Ma}$ stratovolcanic sequence and numerous 52$62 \mathrm{Ma}$ small intrusions and felsic tuffs. In this area latest Laramide deformation occurred after formation of these rocks and prior to formation of $46 \mathrm{Ma}$ untilted volcanic strata.

Time of the onset of Laramide activity affecting the Chihuahua trough is not well defined, but there is evidence that suggests tectonism was underway at the beginning of the Laramide time slice. Denison et al. (1970) interpreted K-Ar dates on micas from probable late Paleozoic rocks at Sierra Samalayuca (Figure 1) as effects of a 78 to $84 \mathrm{Ma}$ period when the rocks were under substantial load and undergoing higher than normal temperatures. López-Ramos (1988) mentioned 83 Ma igneous rocks in PEMEX Camello-1, located in the extreme northwestern part of the Chihuahua trough (east of the Big Hatchet Mountains), which can be interpreted as earliest Laramide igneous activity. By this time (early Campanian), the Chihuahua trough had ceased to exist and the seas were retreating, toward the southeast, in a foreland basin (Tornillo basin; ca. 40-80 Ma) sub- parallel to and along the present course of the Rio Grande between the Van Horn Mountains (Figure 1) and northwestern Coahuila (Lehman, 1991; Stevens and Stevens, 1985, 1990).

\subsection{Structure and tectonic style}

The Chihuahua trough and tectonic belt are divided into eastern and northwestern areas in this discussion (see Figure 1 for boundary). In general, ranges in the eastern area trend more northerly than west-northwest trending ranges in the northwestern area. The boundary between the areas is along a north-trending component of the pre-Jurassic opening fabric (Figure 3A) and is coincident with a major strike-slip fault system postulated by Eguiluz de A. (1984). Eguiluz de A. called this the Juárez fault and suggested left-lateral displacement of more than $10 \mathrm{~km}$ during late Oligocene and early Miocene time. The boundary between the eastern and northwestern areas is along the north-trending zone of Laramide intrusive and volcanic rocks in central Chihuahua described by McDowell and Maugher (1994), and is the locus of Laramide intrusions at Cerro de Muleros (along the border west of El Paso) and at the campus of The University of Texas at El Paso (Campus Andesite, 48.4 Ma, Henry and McDowell, 1986). Suffice to say the boundary between the eastern and northwestern sections of the Chihuahua trough and tectonic belt is a geological feature of some consequence.

Elements of the regional structural fabric shown by Figure 3A exerted a profound influence on the development of Laramide structure. During the Laramide orogeny the eastern margin of the Chihuahua tectonic belt collided with the buttress formed by a stable Mesozic platform bounded by the northern boundary of the Texas "zone" (Muehlberger, 1980) and a northtrending element of the ancient fabric, along the course of the Rio Grande (more or less coincident with the late Paleozoic Diablo Platform). This zone of collison is the locus of the major Laramide thrust faults of the eastern part of the Chihuahua tectonic belt. Far to the east, Webster (1979; cited by Muehlberger, 1980) has mapped an en echelon system of grabens north and east of Del Rio that requires a left-lateral east-striking shear couple during the Laramide. Muehlberger (1980) noted that this is consistent with known Laramide fault and fold patterns in Trans-Pecos Texas and the Chihuahua trough and suggested that the Mexican and Big Bend segments moved east relative to the area to the north [of the Texas "zone"]. This is interpreted to indicate leftlateral transpression along elements of the fabric shown by Figure 3A.

This discussion will go into some detail on structures of the eastern area, describe Sierra Juárez (at the boundary between the northwestern and eastern areas), and review structure of the northwestern area of the trough. 


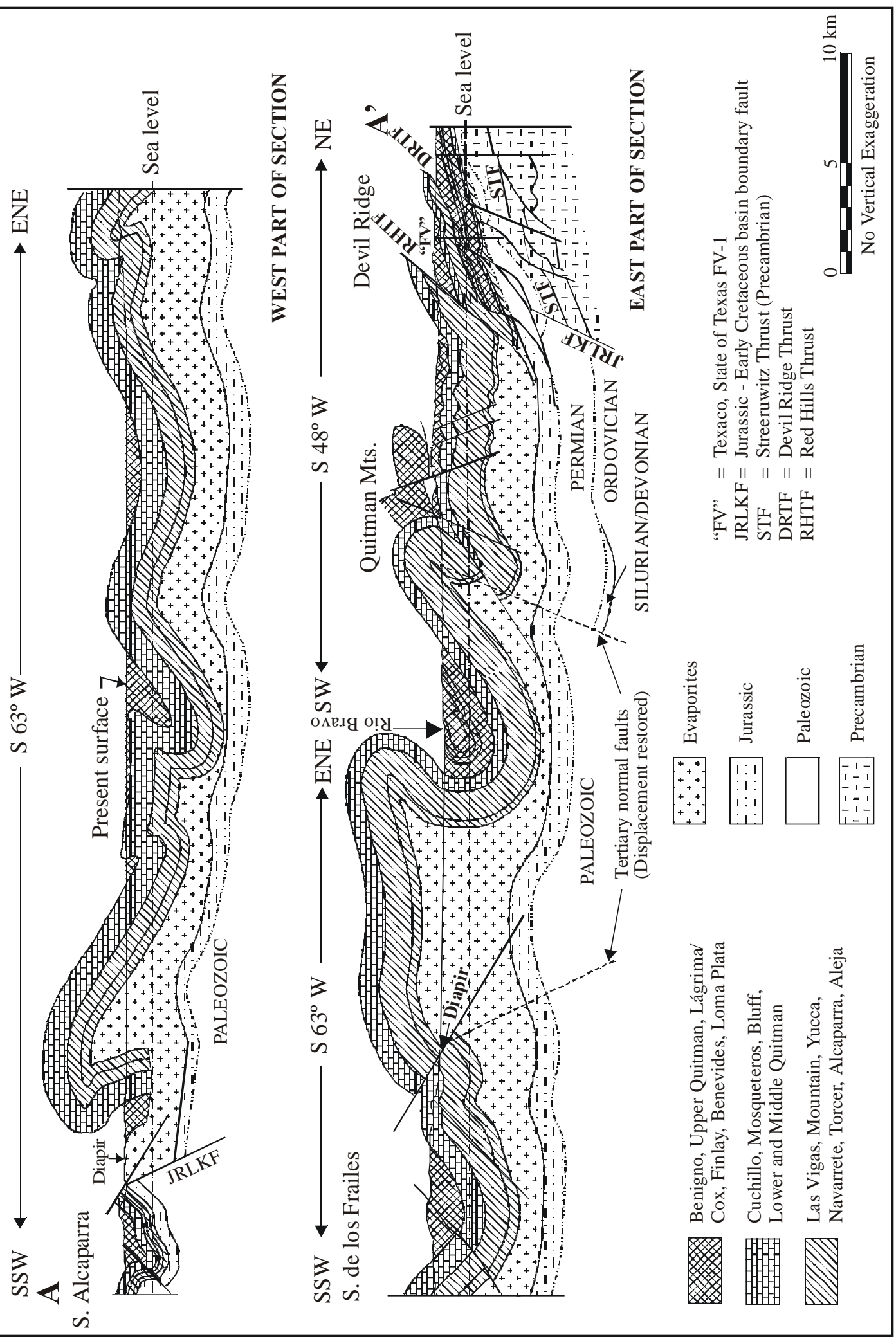

墕

这部

$\approx \sum_{\Sigma}^{\circ}$

in 表

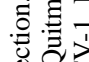

记

苍官苛

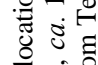

过递

象:

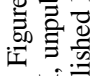

空

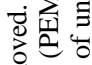

을

莺 胥

要

율

额

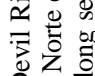

응

을

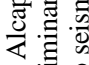

월

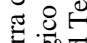

is

ํㅓㄴ

寝

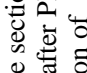

은

总需

\& $\stackrel{\circ}{\circ .}$

항

ज况。

它享:

氙

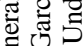

过

४吉总

할

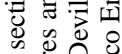

氙家苍

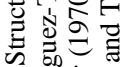

는

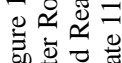

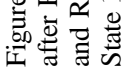




\subsubsection{Eastern area}

The eastern area of the Chihuahua trough extends $380 \mathrm{~km}$ from the Sierra Juárez to the southern end of Sierra Grande and is about $170 \mathrm{~km}$ wide (Figure 1). In general, structures along the eastern margin of the area verge eastward and structures along the western margin verge toward the west (Hennings, 1991, 1994; Figure 10).

No attempt is made here to describe structures of the eastern area in any detail. Published work that describes Chihuahua tectonic belt structures in Texas includes Underwood, (1963), Albritton and Smith (1965), Jones and Reaser, (1970), Berge (1982), and Reaser, (1982). Publications by Gries and Haenggi (1970), Haenggi and Gries (1970), Gries (1979, 1980), Harkey and Dyer (1985) and Hennings (1994) describe structures in Chihuahua. Unpublished Ph.D. dissertations by Bridges (1962), Underwood (1962), Haenggi (1966), Jones (1968), Gries (1970), Reaser (1974), Monreal (1989), and Hennings (1991), describe and interpret structure of various parts of the tectonic belt in Texas and Mexico.

Practically all of the folding and most of the faulting in the eastern area is the result of Laramide deformation. Disharmonic folding between Jurassic-Neocomian evaporites, incompetent units (including gypsum) of the Cuchillo Formation, the incompetent Benevides and Ojinaga formations and thick competent units resulted in large asymmetrical, parallel-style folds throughout the area (Figures 10, 11 and 12). With the exception of thrust faulting in the Placer de Guadalupe - Carrizalillo region (Figure 1), all mapped major thrust faults occur near the boundary between the Chihuahua trough and the Diablo Platform; thrusting is directed toward the platform. Laramide structure in the eastern area of the Chihuahua trough involves décollement within the Jurassic-Neocomian evaporite section, evaporite flow and local diapiric injection of the evaporites. Thrust faults and overturned folds occur along margins of evaporite basins and fold vergence is toward the east and west. Maximum displacement along thrusts is estimated as 5 or $6 \mathrm{~km}$ (Devil Ridge thrust fault, Figure 10), but typical displacements of major thrusts are less than $3 \mathrm{~km}$. Thrust faulting in the Placer de Guadalupe - Carrizalillo area (thrusting toward the southwest, see Figure 7 of Haenggi, 2001) and in the Devil Ridge area (thrusting toward the northeast, Figure 10) involves Paleozoic sedimentary rocks, and, at Carrizalillo, Precambrian basement is apparently involved in Laramide structure. Hennings (1991, 1994) and Haenggi (2001) inferred that Precambrian basement is also involved in Laramide thrusting at Placer de Guadalupe.

Structural Development. Three hypotheses have been advanced for the structural development of the eastern area of the Chihuahua tectonic belt:

1) Haenggi and Gries (1970), Gries and Haenggi (1970) and Gries (1980) advocated evaporite tectonics as the primary control for Laramide deformation. Their interpretation was that Paleozoic basement was slightly deformed or tilted and that the Cretaceous section, above the evaporites, was folded and thrust faulted as the entire section moved relatively eastward and encountered the Diablo Platform buttress. Vergence is predominantly toward the east but there are numerous west-verging structures. After the primary phase of deformation, diapiric injection of evaporites and associated faulting continued. Gries and Haenggi (1970) and Gries (1980) noted that regional extension and dropping of the basin margin, along the Diablo Platform, could cause the same structural regime as the compression hypothesis.

2) The second theory is the outgrowth of the observation that there is apparent continuity of folds and thrusts of the Cordilleran orogenic belt throughout western North America. Drewes (1978) postulated that the Chihuahua tectonic belt is an example of Jura-style deformation characterized by symmetrical and upright to asymmetrical folds with the majority of axial planes dipping to the west. Hennings (1994) described the Chihuahua tectonic belt as the southern continuation of the Cordilleran fold belt and presented a structural transect showing major sole thrusts as the control for observed structures.

3) The third theory is based on the observation that the southwestern boundary of North America has been a transform boundary at various times and that some deformational episodes involve strike-slip movement. Dickerson (1985) suggested that deformation was the result of left-lateral Laramide transpressional tectonics. Monreal (1989) and Monreal and Longoria (1995), in comparisons of observed structure in the Chihuahua tectonic belt with analog models of folds above a basement wrench fault (Odonne and Vialon, 1983), concluded that transpressive tectonics, related to several basement strike-slip faults oriented $\mathrm{N} 50^{\circ}$ to $\mathrm{N} 60^{\circ} \mathrm{W}$, caused Laramide deformation.

The transpression theory (3), with enhancement of folding and thrusting by evaporite flow, is advocated here. Thrusting and fold overturning is directed toward the edges of the postulated Jurassic-Neocomian evaporite basins.

The postulated sequence of development of Laramide structures is:

1) Reactivation of Jurassic-Aptian basin-boundary faults as reverse faults, with possible left-lateral components of motion, accompanied by development of gentle "ancestral" folds in pre-evaporite "basement" (initiated by deep-seated oblique slip reverse faulting?) and Mesozoic rocks. All major folds in the area are initiated.

2) Amplification of folds in post-evaporite Mesozoic rocks as evaporties flowed from synclines toward crests of anticlines.

3) Development of thrust- and tear-faults along margins of evaporite basins. Intrusion of evaporites along tear- and thrust-faults. Initiation of normal faulting to compensate for flow of evaporites and to compensate for greater shortening of Mesozoic strata than of 


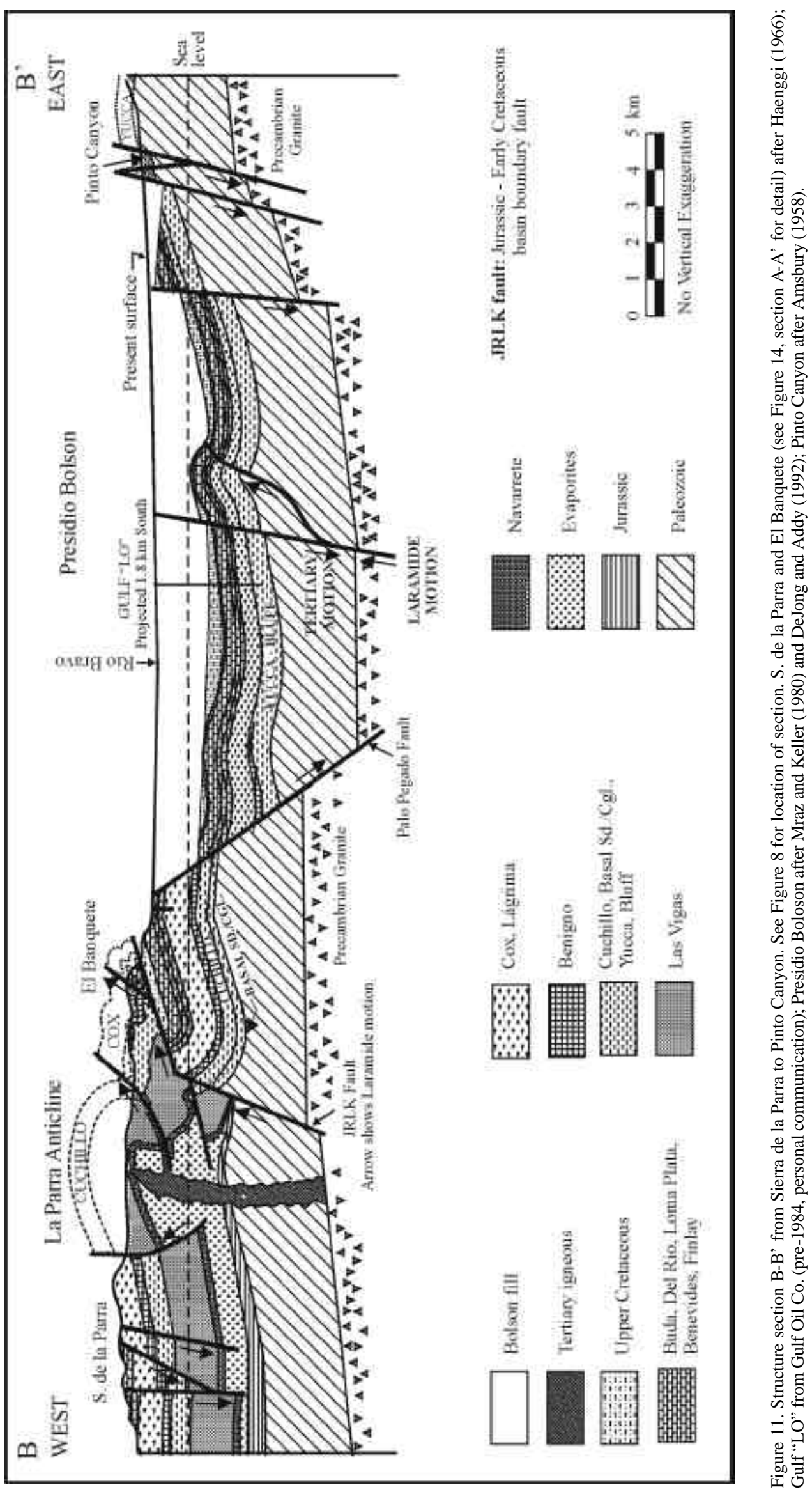




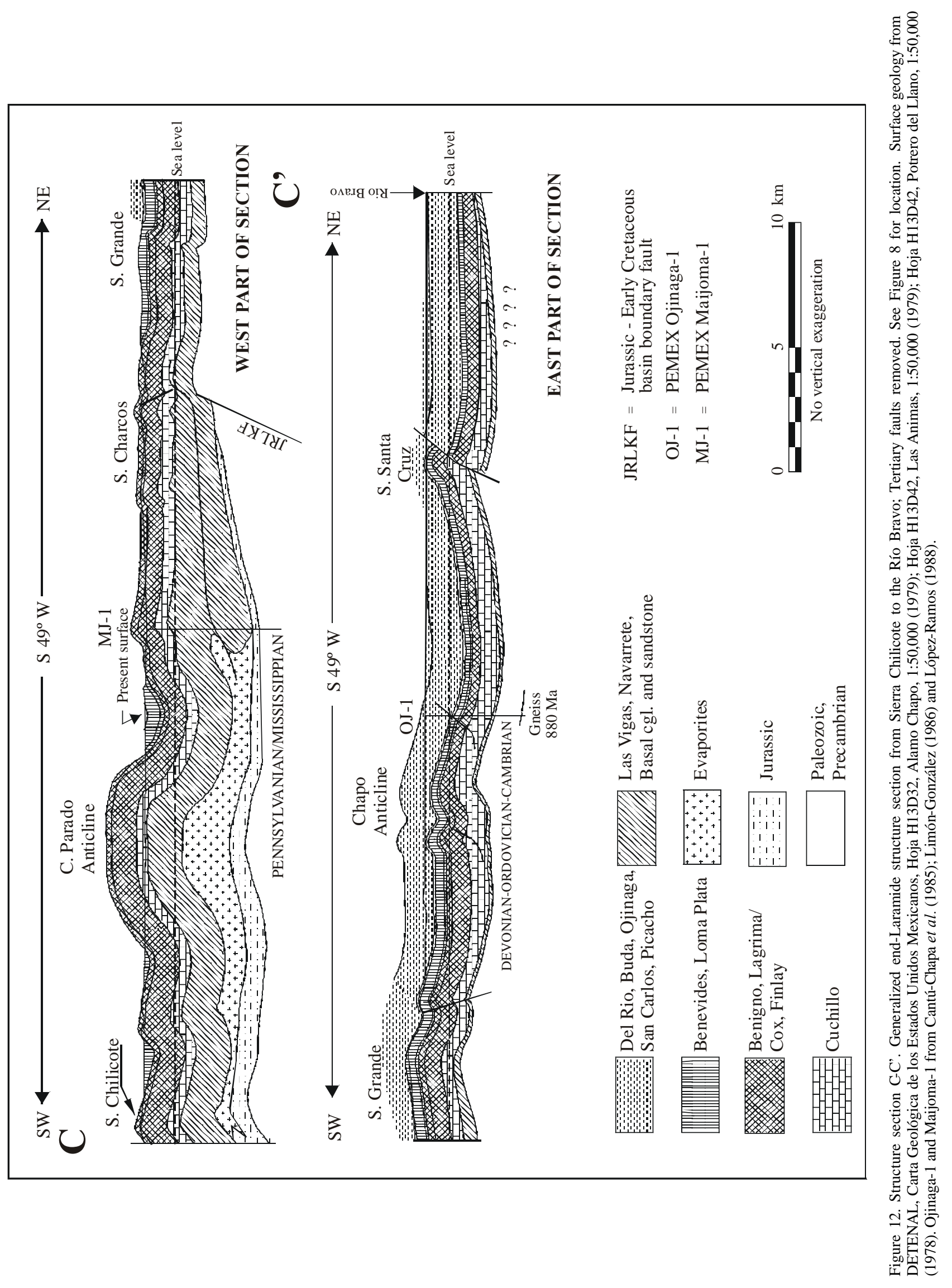




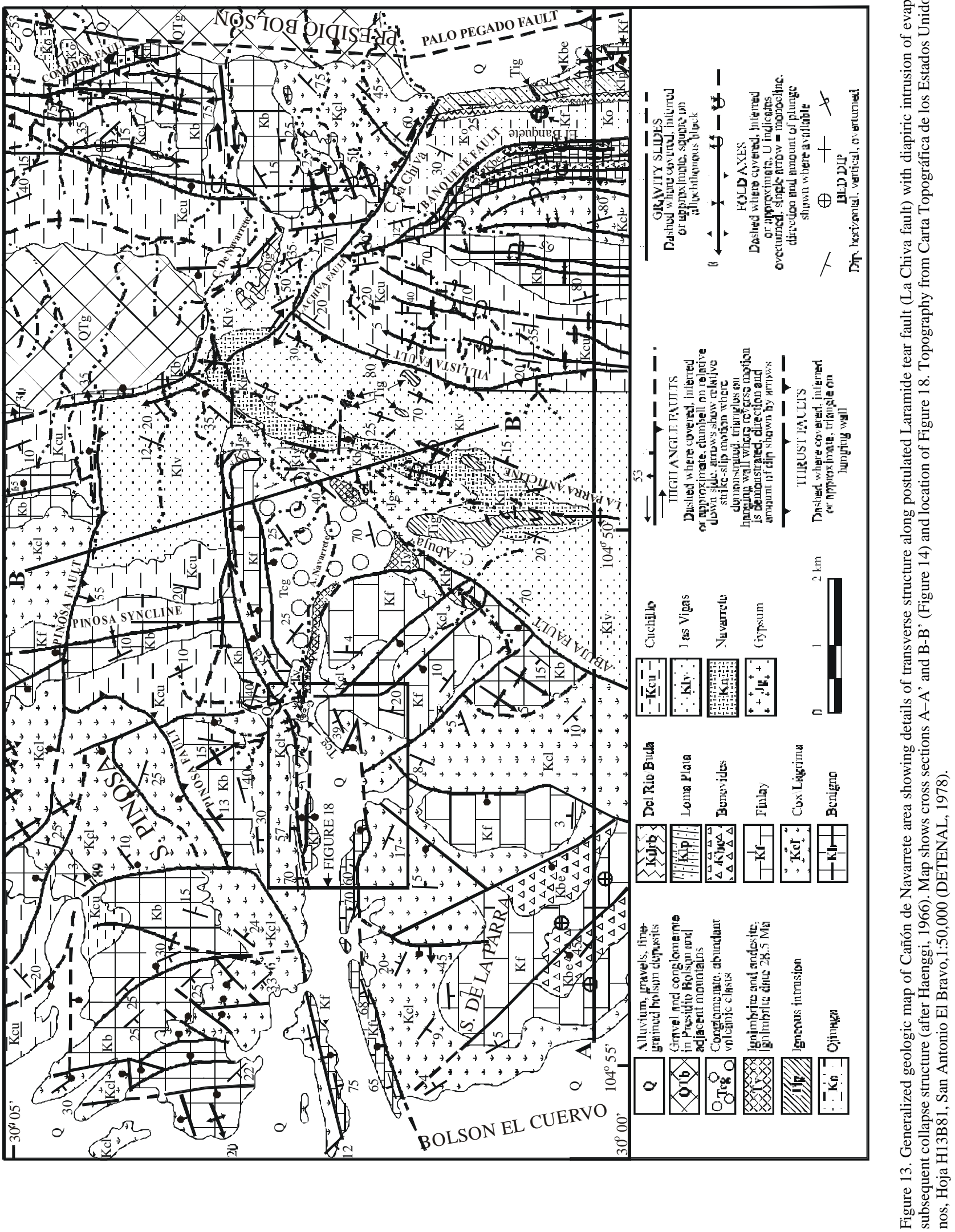


pre-evaporite "basement".

4) Continuation of folding and probably of evaporite intrusion. Superposition of fault systems related to folds (e.g., perianticlinal faults of Borrachera anticline, in Sierra Pilares (Figure 1), that offset the Pilares thrust fault). Development of second generation of thrust faults as folding continued (e.g., Villista fault, Figures 13 and 14). Adjustments along normal faults whenever there was evaporite flow.

Basic Premise. The basic hypothesis incorporated into the interpretation of the structural evolution of the eastern area of the Chihuahua tectonic belt is based on two assumptions about Jurassic-Neocomian evaporites: 1) The eastern edge of the evaporite basin is west of postulated Jurassic-Aptian basin-bounding faults and is sub-parallel to the Devil Ridge - Eagle - Indio Pilares - Pinosa - La Parra - Sierra Grande chain of mountains (Figure 1) henceforth referred to as the La Mula - Sierra Blanca Range, and 2) evaporites have been injected into younger (and possibly older) rocks along zones of faulting. The first assumption, concerning the extent of the evaporite basin, involves some circular reasoning because structural style is used to define the limits of evaporites shown by Figure 8 and the evaporites are then incorporated into interpretation of structure. It should be reiterated that Jurassic-Neocomian evaporites are not inferred to be present over the entire eastern area of the Chihuahua trough (Figure 8).

Shortening. The principal reason for this discussion on shortening is to demonstrate that Laramide shortening in the Chihuahua tectonic belt is less than typical $50 \%$ or more shortening of thrust belts and is consistent with shortening in inverted basins that are internal to continental margins.

Hennings (1991) constructed four balanced cross sections across the eastern front of the Chihuahua tectonic belt. He also constructed a 170-km structural transect, across the entire Chihuahua tectonic belt, between Ojinaga and Aldama, Chihuahua (Hennings, 1991; 1994). From three sections Hennings (1991) found that Laramide shortening in the "northern segment" (area along the Rio Grande between the southern edge of the Finlay Mountains and the southern end of the Indio Mountains; see Figure 1) is about 39\%. Between the Indio Mountains and the southern boundary of the Chihuahua trough ("central" segment (one section) and "southern" segment (transect) of Hennings), shortening is on the order of $10 \%$. Hennings (1991) estimated the mean transport direction of the "Laramide" front as $\mathrm{N} 78^{\circ} \mathrm{E}$ and assumed that deformation progressed from west to east. His explanation of the "gross difference in shortening" between his "northern segment" and the area to the south is that the deformation front encountered basement faults (basin-bounding faults) adjacent to the "northern segment" before those to the south. Deformation ceased after 39\% shortening in the "northern segment"; a time sufficient to cause only $8 \%$ shortening in the "central" and "southern" segments. In effect, the difference in shortening is the result of an oblique collision between the deformation front and Jurassic-Aptian boundary faults of the Chihuahua trough.

Section AA' (Figure 10) is along the same line as Hennings (1991) Devil Ridge - Northern Quitman Mountains section (DRQM). A-A' crosses the entire eastern area of the Chihuahua trough and extends $76 \mathrm{~km}$ into Chihuahua beyond the end of Hennings DRQM section (Rio Grande). Construction of A-A' (and all other cross sections) does not utilize section-balancing algorithms. Laramide shortening is calculated by measurement of the length of a deformed and faulted contact near the middle of the Cretaceous statigraphic section depicted by each section and dividing this value into the present length of the section. For example, in Section A-A', the length of contact at base of Cuchillo/ Mosqueteros/Bluff/Quitman section divided into the distance between $\mathrm{A}$ and $\mathrm{A}^{\prime}$ multiplied by 100 and then subtracted from $100 \%$. Shortening across the entire section $\mathrm{A}^{-\mathrm{A}^{\prime}}$ is $24 \%$ and, for the part of the section that coincides with Hennings DRQM, shortening is $35 \%$, in good agreement with his value of $39 \%$.

Section B-B' (Figure 11) is about $30 \mathrm{~km}$ south of Hennings' (1991) "central" segment section called Northern Sierra Grande (NSG). For section NSG Hennings derived 7\% Laramide shortening. Shortening along $\mathrm{B}-\mathrm{B}^{\prime}$ is estimated as $10 \%$, in agreement with Hennings' conclusions on shortening in the "central" segment of the Chihuahua tectonic belt.

Section C-C' (Figure 12) was constructed to pass through PEMEX wells Maijoma-1 (MJ-1) and Ojinaga-1 (OJ-1) and is 10 to $26 \mathrm{~km}$ south of Hennings (1991; 1994) structural transect (C-C' trends $\mathrm{S} 49^{\circ} \mathrm{W}$ vs. S65 ${ }^{\circ} \mathrm{W}$ for the transect). Larmide shortening along $\mathrm{C}-\mathrm{C}$ ' is about $5 \%$. C-C' corresponds to the "eastern allochthon" of Hennings' transect where he reported $8 \%$ shortening. Hennings" "western allochton" is shortened 22\%, and total shortening of his transect is $13 \%$. Hennings' "western allochthon" includes the Placer de Guadalupe structure that he assumes is entirely a Laramide feature. In Part I of this paper (Haenggi, 2001), the Placer de Guadalupe structure is interpreted as a late Paleozoic fold that was the locus of a small Jurassic island in the Chihuahua trough and was subsequently involved in Laramide deformation (see Figure 7, Part I). Estimates of shortening along the Placer de Guadalupe cross sections during Paleozoic and Laramide deformation (Haenggi, 2001) are $16 \%$ and $12 \%$ respectively for a total of $28 \%$. This estimate of total shortening (Paleozoic plus Laramide) is similar to the Laramide shortening of Hennings" (1991, 1994) "western allochthon" (22\%). It is suggested that the actual Laramide shortening of this part of the Chihuahua tectonic belt is about $10 \%$, a value consistent with data presented here and by Hennings (1991) for the "central" and "southern" segments of the eastern area of the belt. 
Construction and interpretation of cross sections A-A', B-B', and C-C' has not resulted in any change of Hennings' (1991) observations on Laramide shortening in the Chihuahua tectonic belt nor in his basic interpretation of the causes of the "gross difference in shortening" between the "northern" and "central"-"southern" segments of the belt. Nevertheless, his interpretation might be modified or changed completely when distribution of evaporites within the Chihuahua trough is considered. Examination of the postulated evaporitebasin distribution (Figure 8) shows that the evaporite basin is much wider (about $90 \mathrm{~km}$ ) in the north than in the central and southern parts of the trough (about $40 \mathrm{~km}$ ). Also evaporites abut basin-bounding faults in the north (data from Border Exploration BASK State 9-1 (BSK 9) and Texaco Emmett Unit-1 (EM) support this; see Table 3) and, to the south, original positions of evaporites are inferred to be about $10 \mathrm{~km}$ west of the boundary faults (Figure 8). Presumably a greater mass of evaporites was involved in deformation of the northern area than to the south. If correct, this could cause greater amplification of folds in the north and increase calculated Laramide shortening.

Cañón de Navarrete. Many of the conclusions and hypotheses presented here, including the postulated sequence of Laramide events, are the outgrowth of studies of El Cuervo Area (Haenggi, 1966). El Cuervo Area (see Figure 1 for location) is slightly larger than the area bounded by Latitude $30^{\circ} \mathrm{N}$, Latitude $30.5^{\circ} \mathrm{N}$, the Río Bravo (Rio Grande) and Longitude $105.33^{\circ} \mathrm{W}$ (sheets H13A79, H13A89, H13B71, and H13B81 of the 1976-1978 CETENAL 1:50,000 series of the Carta Topográfica de los Estados Unidos Mexicanos). The Cañón de Navarrete area, a small portion of El Cuervo Area, is selected to illustrate hypotheses regarding the role of evaporites during Laramide deformation and some post-Laramide features that will be discussed later (Figure 13). Two cross sections are presented to illustrate the postulated development of the structures discussed (Figure 14).

The transverse structures between Sierra Pinosa and Sierra de la Parra (western part of Figure 13) and along Cañón La Chiva (La Chiva fault, eastcentral part of map) are interpreted as a tear fault system that originally moved in a right-lateral sense (arrows shown on Figure 13) and eventually had left-lateral displacements. During tear faulting there were significant dip-slip components of net slip on the La Chiva fault and the final relative movement is up to the south. Principal evidence for right-lateral tear faulting is the system of folds, interpreted as drag folds, in the Cox-Lágrima and Benigno formations immediately north of Cañón La Chiva. Supporting evidence for the tear fault hypothesis is:

1) The transverse trough along Arroyo Navarrete (and canyon that continues from the arroyo to the western edge of map) trends parallel to the probable direction of overthrusting along the Comedor (northeast corner of map) and Banquete (southeast corner of map) fault systems. If there was faulting along the structure during Laramide deformation, it was probably strike-slip.

2) A small tear fault, along Arroyo Navarrete near the mountain front, proves that tear faulting occurred. The transverse trough has the same trend as the tear.

3) The great structural discontinuity across the La Chiva - Navarrete complex supports this interpretation.

Displacement of the Comedor thrust fault system (inferred to extend south from outcrop beneath bolson deposits), north of the La Chiva fault, is not significantly different from that of the Banquete fault system. If the Comedor and Banquete faults developed simultaneously, and if movement on them was synchronous, this would condemn the hypothesis that the La Chiva fault was a tear during thrust faulting. A two-stage hypothesis to explain this is:

Event 1. If the block to the south was relatively stationary but underwent intense folding, the block north of the La Chiva - Navarrete complex moved eastward, thus a right-lateral tear originated the La Chiva Navarrete structure.

Event 2. The Banquete fault developed near the base of the fold system south of the La Chiva - Navarrete complex. All or part of the southern block moved eastward while the northern block was relatively stationary. Thus a left-lateral tear, with possible up-to-the-south dipslip displacement, during thrust faulting along the Banquete thrust (including the Villista fault) completed the Laramide La Chiva - Navarrete structure.

This hypothesis explains most of the Laramide structural features in the Cañón de Navarrete area. It leads to the following sequence of development:

1) Development of La Parra anticline as a broad symmetrical fold, possible reverse faulting along buried Jurassic-Aptian basin-bounding fault, and initiation of evaporite flow toward the crest of the anticline.

2) Thrusting along Comedor fault accompanied by right-lateral tear on La Chiva fault; amplification of La Parra anticline by continued folding and evaporite flow. As the structure developed, evaporites were intruded into the western part of the transverse structure and a "rim syncline" formed north of diapir.

3) Continuing intrusion of evaporites along transverse structure and into the core of the La Parra anticline caused the Pinosa and Abuja reverse faults (Figures 13 and 14) and overturning of the east flank of the anticline. Evacuation of evaporites from area west of anticline caused normal faulting in Sierra de la Parra.

4) Thrusting along Banquete fault with left-lateral tear on la Chiva fault.

5) Continued flow of evaporites into La Parra anticline and diapir, accompanied by secondary faulting, thrusting along Villista fault and continued leftlateral tear faulting (and dip-slip displacement?) on La Chiva fault. 


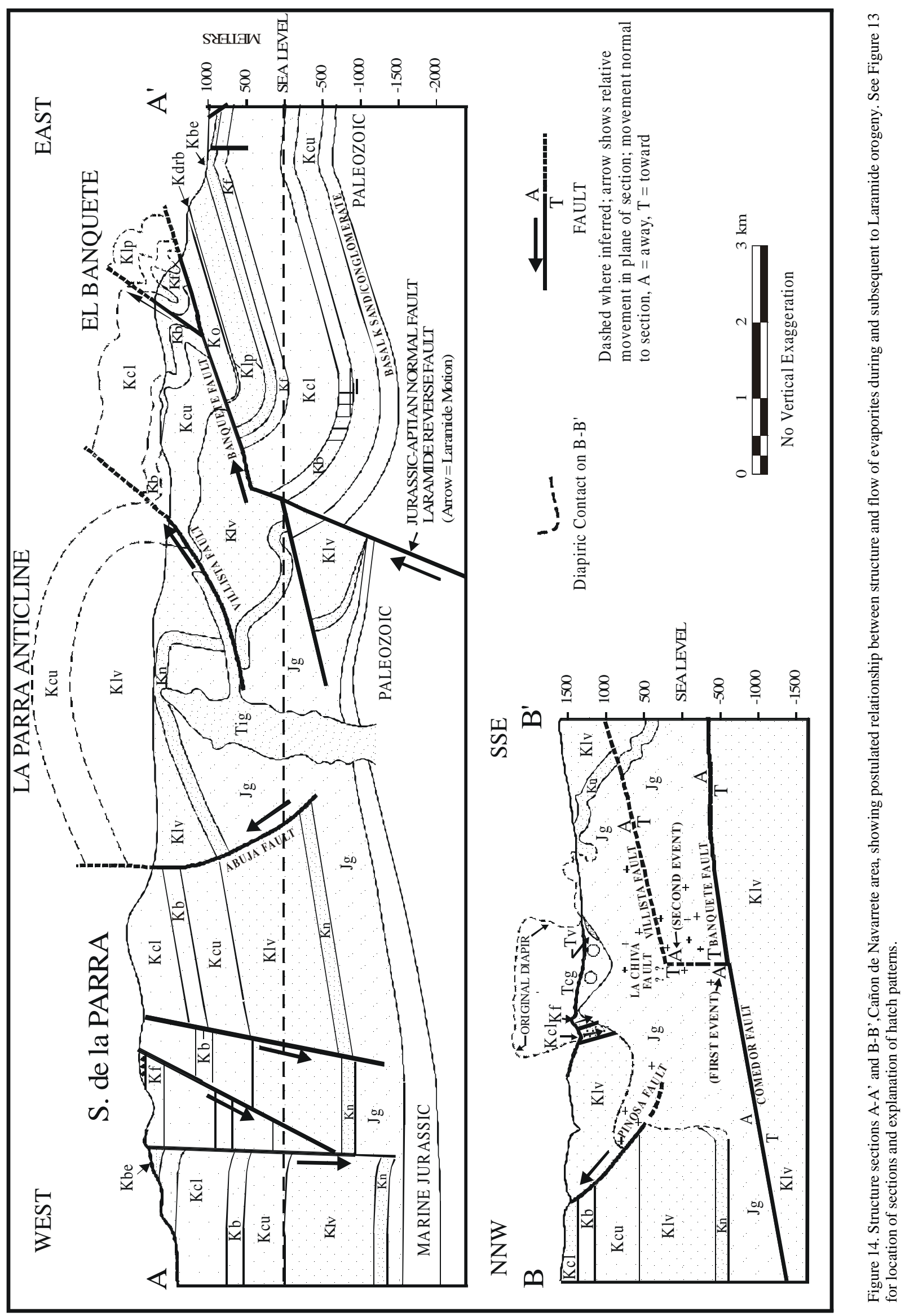


Hueco Bolson. In the Hueco Bolson (Figure 1) two wells south of the Jurassic-Aptian basin-bounding fault (Texas Lineament) apparently encountered reverse faults. In Humble State University DW-1 (ST DW, Figure 8) PEMEX interpreted repeated Permian sections with intervening Jurassic marine rocks (PEMEX files, 1973) and Uphoff (1978) did not recognize reverse faulting. Chambers and Kennedy Surratt-1 (SUR-1, Figure 8), about $20 \mathrm{~km}$ northwest of State University DW-1, found Lower Cretaceous rocks thrust over Upper Cretaceous rocks (Uphoff, 1978; Pearson, 1980). Pearson reported the Cox Formation thrust over Buda Limestone and Uphoff reported Cuchillo Formation thrust over the "Boquillas". According to Pearson (1980) Mobil Dorough-1 (DOR-1, Figure 8), about $3 \mathrm{~km}$ north of Surratt-1, did not encounter repeated sections. In this well Uphoff (1978) interpreted that there are repeated sections of the Benigno and Cuchillo formations, separated by $140 \mathrm{~m}$ of Upper Cretaceous rocks (Boquillas Formation), between the base of bolson fill at $464 \mathrm{~m}$ and the top of the Helms Formation (Mississippian) at $1,339 \mathrm{~m}$ and placed the "Rio Grande" thrust at a depth of $793 \mathrm{~m}$.

Haymond Krupp Thaxton-1 (THX-1, Figure 8), near Campo Grande Mountain, in the southeastern part of the Hueco Bolson, apparently found Lower Cretaceous (Bluff Mesa Limestone) thrust over rocks of Washita age (Albritton and Smith, 1965, Figure 52). Albritton and Smiths' Figure 52 does not agree with an "interpretive $\log$ " in their report (p. 121-122) that described "Upper Cretaceous" faulted against rocks of "Washita age"; if the interpretative $\log$ is correct, there is no repeated section in the well. The thrust interpretation is probably correct because Cannon (1940) reported rocks of the Campagrande Formation (Lower Cretaceous) overthrust on Buda Limestone (Washita) in the well.

The Hueco Bolson is considered by many authors to be the locus of the Laramide "frontal thrust system" (e.g., Drewes, 1988, Hennings, 1991). This interpretation is based on reports of repeated sections in wells in the Hueco Bolson, documented thrusting in the vicinity of the Malone Mountains (Figure 1), immediately southeast of the bolson, (Berge, 1982), some relatively minor thrust faults mapped in the Sierras San Ignacio and San Martin, El Borracho (see Figure 1 for locations; Sociedad Geológica Mexicana, 1985) and the thrust faults of the Sierra Juárez (Figure 1; Drewes and Dyer, 1993). The term "Rio Grande thrust" has been applied to this thrust by at least two authors (Uphoff, 1978 and Hennings, 1991). Hennings described the "Rio Grande thrust" as: "The thrust is not exposed but is thought to have stratigraphic separation of approximately $3 \mathrm{~km}$ ". DeJong and Addy (1992) described the boundary between the Diablo Platform in the Hueco Bolson as: "...marked by a normal fault, down to the southwest with substantial throw [about 1,000 m on Mississippian time-structure map], and the authors' data crosses into the trough where thrust faulting may be observed in the
Permian." Uphoff (1978) placed the boundary between the Chihuahua trough and Diablo Platform between the Suratt-1 and Dorough-1 wells. He described the "Clint fault", between these wells, as a down-to-the south (3,050 m stratigraphic separation in Permian strata) late Paleozoic fault. Uphoff's interpretation is that the Cuchillo Formation (Aptian-Albian) is the oldest Mesozoic unit that is continuous across the "Clint fault" and he suggested that pre-Cuchillo Mesozoic activity along the fault removed any Jurassic rocks that were present to the north of the fault. Figure 15 shows an alternative interpretation to that shown by Uphoff (1978) and Drewes (1991a). Here the "Clint fault" is interpreted as a part of the Texas Lineament and is interpreted as a Jurassic basin-bounding fault that was reactivated during the Laramide orogeny as a reverse fault and again during Tertiary time as a normal fault; Paleozoic faulting along the Clint fault zone is possible but not necessary. Figure 15 also shows a section across the Rim Rock fault, east of the Colquitt syncline (Figure 16), where there is demonstrable Tertiary reactivation of a Laramide reverse fault (see discussion under Faulting; Bolsons and Ranges; Extensional Faulting Along the Eastern Margin in Post-Laramide Tectonism section).

Although there is some evidence of repeated sections in wells drilled in the Hueco Bolson and on seismic lines crossing the bolson in the vicinity of the Finlay and Malone mountains, the presence of a continuous master sole thrust, defining the "front" of the Chihuahua tectonic belt has not been demonstrated. Thrusts shown by the seismic lines described by Berge (1982), Hennings (1991), and probably those of DeJong and Addy (1992) are near the edge of the postulated JurassicNeocomian evaporite basin (Figure 8) and can be interpreted as effects of evaporite tectonism. The structure encountered by the Humble State University DW-1 (ST DW) well (probable repeated Permian sections separated by gypsiferous Jurassic and/or Lower Cretaceous rocks overlying Jurassic rocks) can be interpreted as a décollement within the Jurassic evaporite section. Continuity of thrust faults (presence of a master thrust fault according to several authors) postulated in the Humble State University DW-1, Chambers and Kennedy Surratt-1 and in Mobil Dorough-1 wells (SUR-1 and DOR-1) is suspect because there is no general agreement on the existence of repeated sections in the Mobil and Humble wells. The observed relationships between the Surratt and Dorough wells and possibly the repeated section in the Haymond Krupp Thaxton-1 well (THX) can be explained as the consequence of a system of high-angle reverse faults rather than presence of a Laramide sole thrust within the bolson.

Presidio Bolson. Along the western margin of the Tertiary Presidio Bolson (Figure 1), structures at Cerro Alto and Sierrita mapped by Gries (1970) and at Sierra Santa Cruz (Hennings, 1991, 1994) are interpreted here as Laramide reverse-faulted monocline-like folds (sierras 


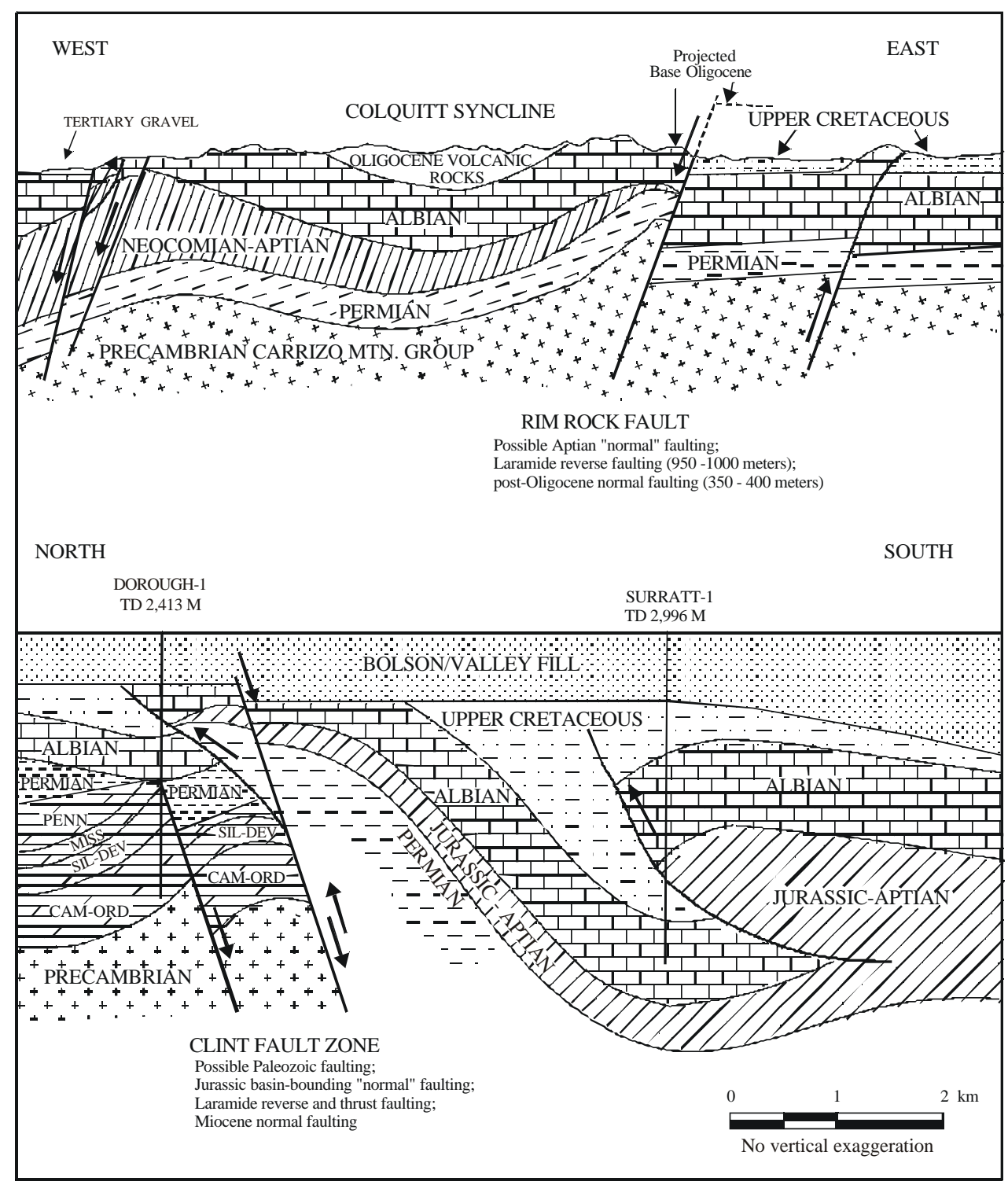

Figure 15. Structure sections Coquitt syncline - Rim Rock fault and Clint fault zone showing postulated Tertiary reactivation of Laramide reverse faults. Colquitt-Rim Rock section based on surface mapping (Twiss, 1959a); Clint fault zone from well data (Uphoff, 1978). See Figure 16 for locations of Colquitt syncline, Rim Rock fault, Dorough-1 and Surratt-1.

not shown on map figures; see Figure 12 for Sierra Santa Cruz structure). This interpretation contrasts with interpretation of these structures to be the result of ramping of extensive sole thrusts (Gries and Haenggi, 1970; Gries, 1971; Hennings, 1991, 1994). Laramide structure within the Presidio Bolson is interpreted to be similar to the structure at Sierra Santa Cruz on Figure 12 (see Figure 11).

With the probable exception of Arco Presidio State-1 (P. ST, Figure 16; DeJong and Addy, 1992) wells drilled in the Presidio Bolson did not encounter repeated sections (Gulf Oil Co., pre-1984 personal communication). The time structure map of DeJong and Addys (1992), contoured on the base of the Woodford Forma- tion, and their northeast-trending section through Arco Presidio State-1 showed a series of northwest-trending high-angle reverse faults in the southern part of the bolson. At the Presidio State well, the section showed a reverse-faulted monocline involving Permian rocks. Several seismic lines in the northern part of the bolson show similar features (Gulf Oil Co., pre-1984, personal communication). These seismic data are the basis for the interpretation of the Laramide reverse-faulted fold within the bolson shown by Figure 11.

East of the Presidio Bolson there are extensive areas of exposure of Tertiary volcanic and intrusive rocks (Chinati Mountains, etc.) to the west, in Mexico, similar rocks are present east of Sierra de la Parra (Figure 1; 


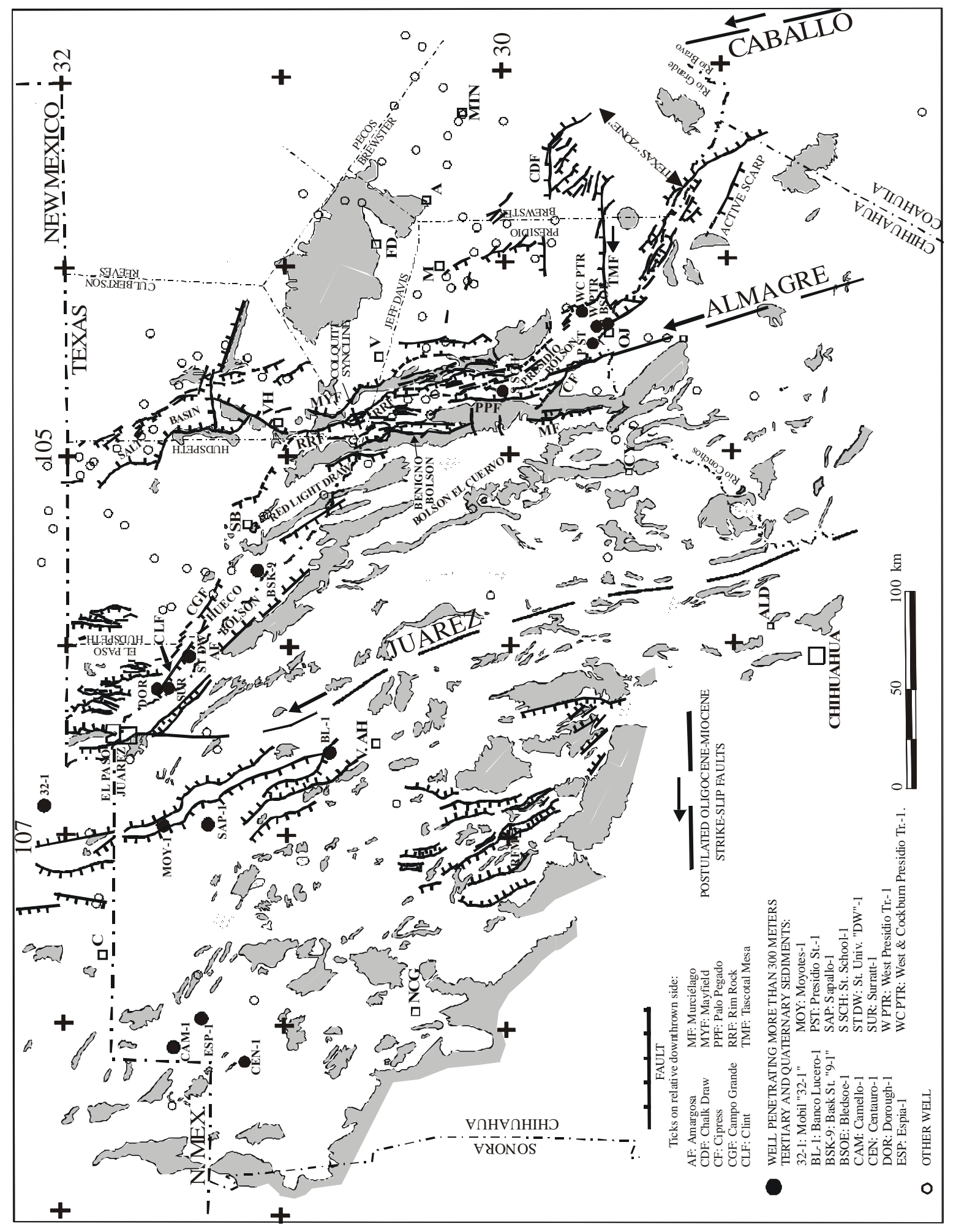

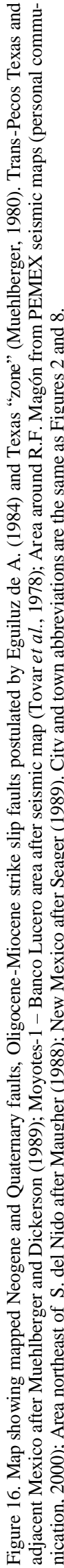


Gries, 1970). Volcanic rocks are also present north and south of the Presidio Bolson in Texas and Chihuahua. At least 7 petroleum exploration wells have been drilled in the Presidio Bolson and all of them found Upper Cretaceous rocks below bolson deposits, but no Tertiary volcanic rocks. There are two possibilities: 1) volcanic rocks were never there, or 2) volcanic rocks have been eroded. Both possibilities require that, at some time, the area of the bolson must have been positive relative to its surroundings; e.g., for 1) a Laramide highland above adjacent areas accumulating volcanic rocks, and for 2) post volcanic uplift, erosion, and inversion to the present structural low.

\subsubsection{Sierra Juárez}

Structure of Sierra Juárez (Figure 1), located at the junction of the eastern and western areas of the Chihuahua trough, is similar to eastern-area structures involving evaporite décollement, but there is no evidence to support the presence of Jurassic or Neocomian evaporites in the area. Drewes and Dyer (1993) described Sierra Juárez as a series of northeast-vergent folds and genetically related thrust plates transported northeastward toward the edge of the Chihuahua trough. The AptianAlbian Cuchillo Formation is the oldest unit recognized in Sierra Juárez and in PEMEX Juárez 1A (JU-1, Figure 8), drilled near the northwestern edge of the mountains (Cuchillo thrust over Upper Cretaceous rocks). Thrust faults shown by Drewes and Dyers' structure sections sole in the Cuchillo Formation. The lower part of the Cuchillo Formation contains "thick beds of sedimentary gypsum" in Sierra del Presidio (Figure 1) about $30 \mathrm{~km}$ south of Sierra Juárez (Webb, 1969), indicating that a Cuchillo evaporite basin(s) exist in the general area and could provide a décollement for the Sierra Juárez structures. If so, arguments regarding the role of evaporites, discussed in the previous section, can be applied to the development of the Sierra Juárez.

The Texas Lineament separates Sierra Juárez from tilted Paleozoic and Precambrian rocks of the Franklin Mountains (Figure 1). The structural contrast is striking and has been the subject of much speculation. Drewes (1988) suggested that overthrust terranes of the Chihuahua tectonic belt abut the Lineament and are more deformed adjacent to it than toward the interior of the belt. Eguiluz de A. (1984) explained the structural discontinuities between the Franklin Mountains and Sierra Juárez and between Sierra del Presidio and Sierra Samalayuca (Figure 1) as evidence for a north-trending Cenozoic (Late Oligocene? or Early Miocene?) leftlateral wrench fault (Juárez fault, Figure 16; more than $10 \mathrm{~km}$ displacement). These ideas are not mutually exclusive; it is quite possible that there was postLaramide displacement of the Jurassic-Aptian basin boundary (Texas Lineament) along the Juárez fault. Should the net result of such movement be a right-lateral offset instead of the left-lateral displacement proposed by Eguiluz de A. (a permissible, if not preferred, interpretation from data presented by Eguiluz de A.), it could account for the somewhat anomalous location of Jurassic marine rocks in the Grimm et al. Mobil 32-1 (32-1, Figure 8) well in New Mexico (Thompson and Bieberman, 1975). In any event, a positive area, to the north of the present Sierra Juárez acted as a buttress during Laramide deformation.

\subsubsection{Northwestern area}

Laramide structure in the northwestern area affects Paleozoic formations but the nature of structural style is not clear. Two contrasting interpretations of Laramide deformation in adjacent Arizona and New Mexico have been advocated: 1) major décollement, within or at the base of the Paleozoic section, with northeast-directed thrusting (e.g., Corbitt, 1988; Drewes, 1991a); and 2) basement-cored uplifts separated by largely undeformed intermontane basins (e.g., Davis, 1979, Seager et al., 1986; Mack and Clemons, 1988). Proponents of the décollement theory believe that the northern margin of the Chihuahua tectonic belt is part of the Cordilleran “overthrust" belt (e.g., Drewes, 1991a).

Brown and Dyer (1987) suggested a faulted basement model for structures they described in northwestern Chihuahua. Their model, with suggested Laramide leftlateral strike slip movement along faults bounding the Jurassic-Aptian basin, is advocated here. It is important to note that this interpretation precludes extension of the Cordilleran "overthrust" belt into the Chihuahua trough.

Corbitt (1988) described thrusting in the Sierra Rica, Chihuahua and New Mexico, Tres Hermanas and East Potrillo Mountains, New Mexico (see Figure 1 for locations), repeated Cretaceous section in PEMEX Camello-1 (CAM-1, Figure 8), Cambro-Ordovician rocks thrust over Lower Cretaceous rocks in Marshall Young's Saltys Unit-1 (not shown) in Grant county, New Mexico, about $15 \mathrm{~km}$ north-northeast of the Little Hatchet Mountains (Figure 1), and apparent repeated section in the Pure-1 Fed. "H" (PU "H", Figure 8) as his principal support for the presence of the overthrust belt in the region. In Chihuahua, northeastward-directed thrusting (apparent continuation of Sierra Rica thrusts) occurs in Sierra Palomas (Figure 1; Sivils, 1987). PEMEX wells Los Chinos-1 (LC-1, Figure 8), south of Sierra Palomas, and Moyotes-1 (MOY-1, Figure 8) encountered Precambrian basement without evidence of thrust faulting; thrust faults should be present in these wells if structural style of the region involves major décollement within the Paleozoic section. Except for PEMEX Camello-1 (CAM-1), repeated sections are apparently absent in the remaining PEMEX wells in the northeastern area shown by Figure 8 (Ascención-1 (ASC-1), Banco Lucero-1 (BL-1), Centauro-1 (CEN-1), Figure 8), Espia-1 (ESP-1), Sapallo-1 (SAP-1), and Villa Ahumada-1 (VH-1)). A reflection seismic line (Tovar-R. et al., 1978, Figure 28) between the PEMEX Centauro-1 (CEN-1) and PEMEX Espía-1 (ESP-1) does not indicate thrust faulting. Depth of the section, in 2-way travel time 
is 4 seconds (fair to good reflectors to about 3 seconds), which corresponds to depths of 10 to $12 \mathrm{~km}$ (estimated from velocity data from a refraction survey reported by Tovar-R. et. al., 1978, p. 111) and should show thrust faulting at or above the maximum depth of sole thrusts (about $5 \mathrm{~km}$ ) postulated by Corbitt (1988) and Drewes (1991a). Tovar-R. et al. (1978, Figure 30) also showed a reflection seismic line through PEMEX (MOY-1), and several lines (Figures 14 and 29) in the vicinity of PEMEX Banco Lucero-1 (BL-1) that do not show thrust faults.

Laramide structures of northwestern Chihuahua reflect northeast-southwest-oriented compression and include relatively minor thrusting directed toward the southwest. Observed southwest-directed thrusting and southwest-verging folds occur along the western margin of the Jurassic basin in the Big Hatchet Mountains (Drewes, 1991b), Sierra de Enmedio, Sierra Bismark (Sierra el Cartucho), Sierra China (Brown and Dyer, 1987) and Sierra Santa Lucia (Sociedad Geológica Mexicana, 1985); see Figure 1 for locations of ranges. With the exception of Sierra China, these structures are on the Jurassic emergent area (Aldama platform) shown by Figure 8 . Northeastward-directed thrusting and associated folding is within (Sierra Rica, Sierra Palomas, and Little Hatchet Mountains) and along the northern margin (Tres Hermanas Mountains, East Potrillo Mountains) of the Jurassic marine basin and is directed toward a Jurassic-Aptian emergent area (Mogollon highlands of Figure 2; Laramide Burro uplift of Seager, 1983).

Brown and Dyer (1987) interpreted the variability in strain and vergence of structures in the northwestern part of the Chihuahua trough as a reflection of basement structure and cited experimental work by Wiltschko and Eastman (1983) and studies in southeastern Arizona as support for their view (e.g., Titley, 1976) that thrust faults dip away from, and stress is concentrated near, rigid basement blocks. Brown and Dyer postulated Laramide deformation of a Mesozoic [Cretaceous] section, underlain by faulted Precambrian and Paleozoic rocks; "basement" faulting occurred during a "mid-Mesozoic" tectonic episode(s) (post early Permian - pre deposition of Aptian-Albian U-Bar Formation). Their "midMesozoic" event(s) is interpreted here to be Late Jurassic-Aptian faulting, accompanied by right-lateral displacements along northwest-trending segments of zones of crustal weakness bounding the North American craton, the pull-apart that formed the Chihuahua trough. Laramide thrusting is directed from the Jurassic marine basin toward Jurassic-Aptian positive areas of the Aldama platform and an ancestral Burro uplift.

Charleston (1981) suggested that compressional stress responsible for the Coahuila folded belt (folded rocks in Sabinas basin) was the result of shearing between the Coahuila-Texas craton and the Coahuila Platform [Island]. In his hypothesis there was Laramide left-lateral wrench faulting along the $\mathrm{La}$ Babia (northeastern basin boundary) and San Marcos (Coahuila
Island boundary) faults, a reactivation of the Jurassic basin-bounding faults (with opposite sense of motion). This hypothesis can be extended to the Chihuahua trough (and Bisbee basin). In the northeastern area of the Chihuahua tectonic belt reactivation of Jurassic-Aptian basin-bounding faults (Figure 2) as left-lateral wrench fault systems and thrusting out of the Jurassic-Aptian basin toward adjacent Jurassic-Aptian positive areas is an explanation of Laramide deformation that is consistent with the observed structural relationships. If correct, this interpretation is compatible with the Laramide transpression theories (discussed in "Eastern area" section) on the origin of the Chihuahua tectonic belt (Dickerson, 1985; Monreal, 1989; Monreal and Longoria, 1995). This conclusion precludes inclusion of the northwestern area (and the remainder of the Chihuahua tectonic belt) in the Cordilleran "overthrust" belt.

In the northwestern area, the postulated Laramide left-lateral wrenching suggested here and by Brown and Dyer (1987) is a speculation and has not been documented in the field. Muehlberger (1980) suggested leftlateral Laramide displacement along the Texas Lineament in Trans-Pecos Texas and infers that the entire Chihuahua tectonic belt is involved. To the northwest, in southeastern Arizona, Drewes (1981) documented and inferred left-lateral strike-slip movement on "northwesttrending complex faults" during the Helvetian (Paleocene-Eocene) stage of his "Cordilleran" orogeny; he attributed strike-slip movement (reactivation of preexisting fault zones) to a change in Laramide stress direction (from $\mathrm{N} 60^{\circ} \mathrm{E}$ to about due east). Conversely, to the north, in southwestern New Mexico, Seager (1983) interpreted drag folding in the Florida Mountains (Figure 1), and at Granite Pass (Figure 1, between the Little Hatchet and Big Hatchet Mountains) as a result of Laramide right-lateral slip.

\section{Post-Laramide tectonism}

In the Chihuahua trough post-Laramide tectonic activity includes a continuation of evaporite tectonism, scattered igneous intrusion and minor volcanism (probable Oligocene-Miocene), possible pre-Miocene faulting, gravity tectonics and late Oligocene-Miocene to Recent block faulting that is generally considered part of the Basin and Range extension and/or formation of the Rio Grande rift. Extensive Eocene-Oligocene volcanism is recorded in areas adjacent to the trough in Trans-Pecos Texas, southeastern Chihuahua (Sierra Rica area, immediately north of Sierra San Carlos; see Figure 1 for location Sierra San Carlos), west central Chihuahua and the panhandle of New Mexico. In at least one area of Trans-Pecos Texas (Colquitt syncline, Figure 16), at the edge of the trough, post-volcanic folding is observed. Studies of dikes, veins, faults and slickensides in TransPecos Texas and Mexico show that the regional stress 
field changed from a compressional to extensional regime around $31 \mathrm{Ma}$ (Henry et al., 1991). In many areas it is difficult to separate Cenozoic tectonic events from Laramide features and to assign structures to specific Cenozoic periods of deformation; many faults that have been active during Cenozoic time are rejuvenated Laramide structures, e.g., Rim Rock and Clint faults (Figures 15 and 16). Since Eocene time the region has been uplifted hundreds of meters from elevations near sea level (present bolson elevations range between 900 and $1,500 \mathrm{~m}$ ). Most of the uplift probably occurred during a period of late Oligocene - early Miocene block faulting. Much of this discussion of post-Laramide tectonism is speculative.

Discussion of evaporite tectonics, formation of collapse structures in areas of diapirs and gravity structures is adapted from field studies of El Cuervo Area (Haenggi, 1966) and Sierra de la Parra Area, immediately south of eastern part of El Cuervo Area, in the La Mula - Sierra Blanca Range (Gries, 1970) and specific examples will be discussed in some detail (see Figure 1 for locations of El Cuervo and Sierra de la Parra areas). The igneous and volcanic history of the area is based on studies in Trans-Pecos Texas and central Chihuahua (several authors; e.g., Henry and McDowell, 1986, McDowell and Maugher, 1994). Pre-Rio Grande rift (ca. $24 \mathrm{Ma}$ ) faulting, other than that associated with evaporite redistribution cannot be demonstrated but there are a few clues in Trans-Pecos Texas that some faulting occurred during Eocene and/or Oligocene time. Basin and Range block faulting, as used here, is the "relative uplift of linear segments of the crust to form mountains and the relative sinking of adjacent segments to form valleys" (Stewart, 1978). Northeastern Chihuahua is included in the Basin and Range province by many authors (e.g., Stewart, 1998).

\subsection{Ignimbrites and Oligocene topography}

Mountains formed during Laramide deformation must have been eroded as they developed and the resultant topographic relief was not extreme. Much of the eroded material was deposited in the Tornillo basin along the eastern border of the Chihuahua trough during the interval between 80 and $40 \mathrm{Ma}$ (Lehman, 1991). Post-40 Ma erosion products were eventually deposited in deltas of the Rio Grande. There is considerable evidence that the topography of the Chihuahua tectonic belt during emplacement of Oligocene ignimbrite was very similar to the topography of today. This conclusion is based on ignimbrite outcrops mapped in Sierra de la Parra area (Gries, 1970) and, in El Cuervo area, on ignimbrite exposed in Cañón de Navarrete, and scattered ignimbrite outcrops in Sierra Lágrima (Haenggi, 1966). Gries (1970) and Haenggi (1966) tentatively correlated ignimbrites with the Mitchell Mesa Rhyolite (32.3 Ma, Henry and McDowell, 1986) of Trans-Pecos Texas.
Correlations are based on lithology and may be, in part, suspect because a K-Ar date of $28.5 \pm 1.4 \mathrm{Ma}$ was obtained from phenocrysts in the Cañón de Navarrete ignimbrite (Gries, 1970). In any event, the ignimbrites described by Gries and Haenggi were deposited on a topography that developed on deeply eroded Laramide structures prior to the time when all caldera source areas in Trans-Pecos Texas and adjacent Chihuahua were active (38-28 Ma, Henry and Price, 1984).

In Cerros Prietos, immediately east of Sierra de la Parra (Figure 1), Heiken (1966) and Gries (1970) mapped a volcanic sequence resting on and overlapping all exposed Cretaceous formations from the Cuchillo through the Ojinaga. Within Sierra de la Parra, Gries (1970) showed scattered volcanic rock outcrops unconformable on all exposed, folded Cretaceous formations. Exposed volcanic sections in Cerros Prietos and Sierra de la Parra consist of or contain an ignimbrite that Heiken (1966) and Gries (1970) tentatively correlated with the Brite Ignimbrite (DeFord, 1958b), the same lithostratigraphic unit as the Mitchell Mesa Rhyolite (32.3 Ma, Henry and McDowell, 1986). The Mitchell Mesa is the most widespread volcanic unit in TransPecos Texas and is generally regarded as a product of the Chinati Mountains (Figure 1) caldera located some $25 \mathrm{~km}$ northeast of areas of ignimbrite exposures in Cerros Prietos - Sierra de la Parra. Extension of the known outcrop area of the Mitchell Mesa as shown by Henry and McDowell (1986, Figure 6) to the Sierra de la Parra seems reasonable.

In the eastern foothills of Sierra Lágrima (Figure 1) Haenggi (1966) found a large outcrop area (about $2 \mathrm{~km}^{2}$ ) and several smaller outcrops of a similar ignimbrite resting on deformed rocks of the Las Vigas Formation. West of Sierra Lágrima, near La Bamba (Figures 1 and 17), he found an ignimbrite on a slide block of Finlay Limestone. A tentative correlation of these ignimbrites with the Mitchell Mesa Rhyolite is suggested.

Haenggi (1966) mapped an ignimbrite in Cañón de Navarrete (Figure 13) and suggested that it correlates with the Brite-Mitchell Mesa. Subsequently a K-Ar date of $28.5 \pm 1.4 \mathrm{Ma}$ was obtained from phenocrysts from this unit (Gries, 1970). This is too young to be Mitchell Mesa but is similar to the age of the Santana Tuff (28 Ma, Gregory, 1981; cited by Henry and Price, 1984). The Santana Tuff was derived from the Sierra Rica caldera located in the general area of the Sierra San Carlos, Chihuahua (Figure 1 for location Sierra San Carlos) and the Santana Tuff is known to have escaped the caldera (Henry and Price, 1984). Perhaps the Cañón de Navarrete ignimbrite (and some of the other ignimbrites in Chihuahua) is equivalent to the Santana Tuff.

An unpublished structure map by Amsbury and Haenggi, on the base of the presumed Mitchell Mesa Rhyolite in Chihuahua, shows present elevations of the base of the unit ranging between 1,300 and $1,800 \mathrm{~m}$ within Sierra de la Parra, 1,100 to about 1,250 $\mathrm{m}$ in the Cerros Prietos area, and between 1,300 and 1,520 in 
Sierra Lágrima. From the structure map, minor faulting is apparent in the Cerros Prietos and Sierra Lágrima. In Sierra de la Parra, the Murciélago fault (Figure 16) has a maximum stratigraphic throw on ignimbrite of about $500 \mathrm{~m}$. The map is readily interpreted to show that the ignimbrite was deposited on a relatively low-relief topography $(200-300 \mathrm{~m})$ and has been subsequently tilted along normal faults. Maximum ignimbrite dip in Sierra de la Parra is about $20^{\circ}$, dips as great as $25^{\circ}$ occur along the Presidio Bolson boundary fault in Cerros Prietos (Cipress fault, Figure 16) and a maximum of $10^{\circ}$ is recorded near a fault in the Sierra Lágrima. In the northwestern part of Sierra de la Parra typical dip of the ignimbrite is 5 to $6^{\circ}$ toward Bolsón El Cuervo (west dip) and in Sierra Lágrima there is a similar tilting toward the bolson (east dip).

\subsubsection{Summary}

Oligocene Mitchell Mesa and/or Santana tuffs flowed across irregular topography caused by erosion of the Chihuahua tectonic belt. Widespread outcrops of these tuffs in El Cuervo and Sierra de la Parra areas show that post-Oligocene erosion has resurrected the Oligocene topography of the tectonic belt.

\subsection{Evaporite tectonics}

It is impossible to separate Laramide high-angle faults related to evaporite tectonism and possible postLaramide faulting, caused by continued evaporite redistribution, but some speculations will be discussed.

Gries (1970) and Gries and Haenggi (1970) postulated that crestal normal faults associated with large Laramide anticlines in the La Mula - Sierra Blanca Range (e.g., Porvenir-Gaitán and Sierra Grande anticlines in Sierra de la Parra area - not shown by figures) might indicate evaporite flowage that continued after Laramide folding and thrusting ceased. The hypothesis is that these faults and others associated with them were activated by evaporite flow from the western limbs (evaporite-basin side) of principal anticlines of the range towards the crest of the folds (to the east) and, possibly toward the west into a large anticlinal structure, concealed by Bolsón El Cuervo (Figure 16).

The initial normal movement that can be documented on these faults was apparently during the latter stages of Laramide overturning and thrusting toward the east. Faulted Oligocene volcanic rocks indicate either slow continuous movement of evaporites after Laramide deformation or reactivation of the Laramide faults during a block-faulting episode(s). The Murciélago fault (Figure 16), a good example of a crestal fault, has a maximum stratigraphic throw of $1,830 \mathrm{~m}$ of which 365 to $500 \mathrm{~m}$ is post-emplacement of Oligocene volcanic rocks. Significantly, the major activity along the fault is in pre-volcanic rocks and must be older than most of the block faulting superimposed on Laramide structure in the region. The locus of the fault is at the edge of the Jurassic evaporite basin and it is inferred here that the initial Laramide movement at that location was a reactivation of the basin-bounding normal fault as a reverse fault (discussed in the section in the Laramide Orogeny section under Eastern area). In this interpretation subsequent normal movement is caused by evaporite tectonism and the section below the evaporites is not faulted. Alternatively, the fault could be interpreted as a normal fault affecting Tertiary, Mesozoic, Paleozoic and Precambrian rocks.

Haenggi (1966) argued that practically all of the normal faulting in Sierra Pinosa (Figure 1) is caused by differential settling of blocks as evaporites were redistributed during the Laramide orogeny and that there could be significant post-Laramide movements on these faults during periods of post-Laramide evaporite flow. The southern Sierra Pinosa, especially west of the Pinosa syncline, exhibits a much more complex system of faulting than areas to the north or south (see Figure 13 for part of this area). Haenggi interpreted this as a consequence of greater redistribution of evaporites in the southern Sierra Pinosa than anywhere else in the La Mula - Sierra Blanca Range and suggested that flow toward diapirs in Cañón de Navarrete (Figures 13, 14, and 16) and Arroyo Cuatralbo (E, Figure 8) exacerbated differential settling of blocks as evaporites flowed into the diapirs; a process that could have continued after Laramide deformation.

\subsection{Gravity tectonics}

Haenggi (1960) mapped flaps and detached flaps (Harrison and Falcon, 1936) along the west flank of Sierra Lágrima and east of Sierra Ventana and Gries (1980) described a flap in the Sierra de la Parra (see Figure 1 for locations of ranges). Collapse structures, involving Cretaceous and Tertiary volcanic and volcaniclastic rocks, are exposed in Cañón de Navarrete and Arroyo Cuatralbo (D and E, Figure 8) and were described in some detail by Haenggi (1966) and Gries and Haenggi (1970). These types of structures have not been reported from other areas of northeastern Chihuahua but careful field mapping might reveal that gravityinduced structures are present elsewhere. Favorable areas to search for flaps are the western flank of Sierra del Fierro (Figure 1) and the area north of Sierra Samalayuca (Figure 1); collapse structures may be present in Cañón de los Frailes (J, Figure 8). Hennings (1991) suggested that blocks of rocks that he assigned to the Plomosas Formation, located near Estación Picachos (midway between Falomir and San Sostenes, see Figure 1 for locations), that King and Adkins (1946) mapped as a thrust, are slide blocks (minimum displacement $10 \mathrm{~km}$ ) of Plomosas onto the Las Vigas and Cuchillo formations; these blocks could be detached flaps off the Laramide structure to the southwest. 


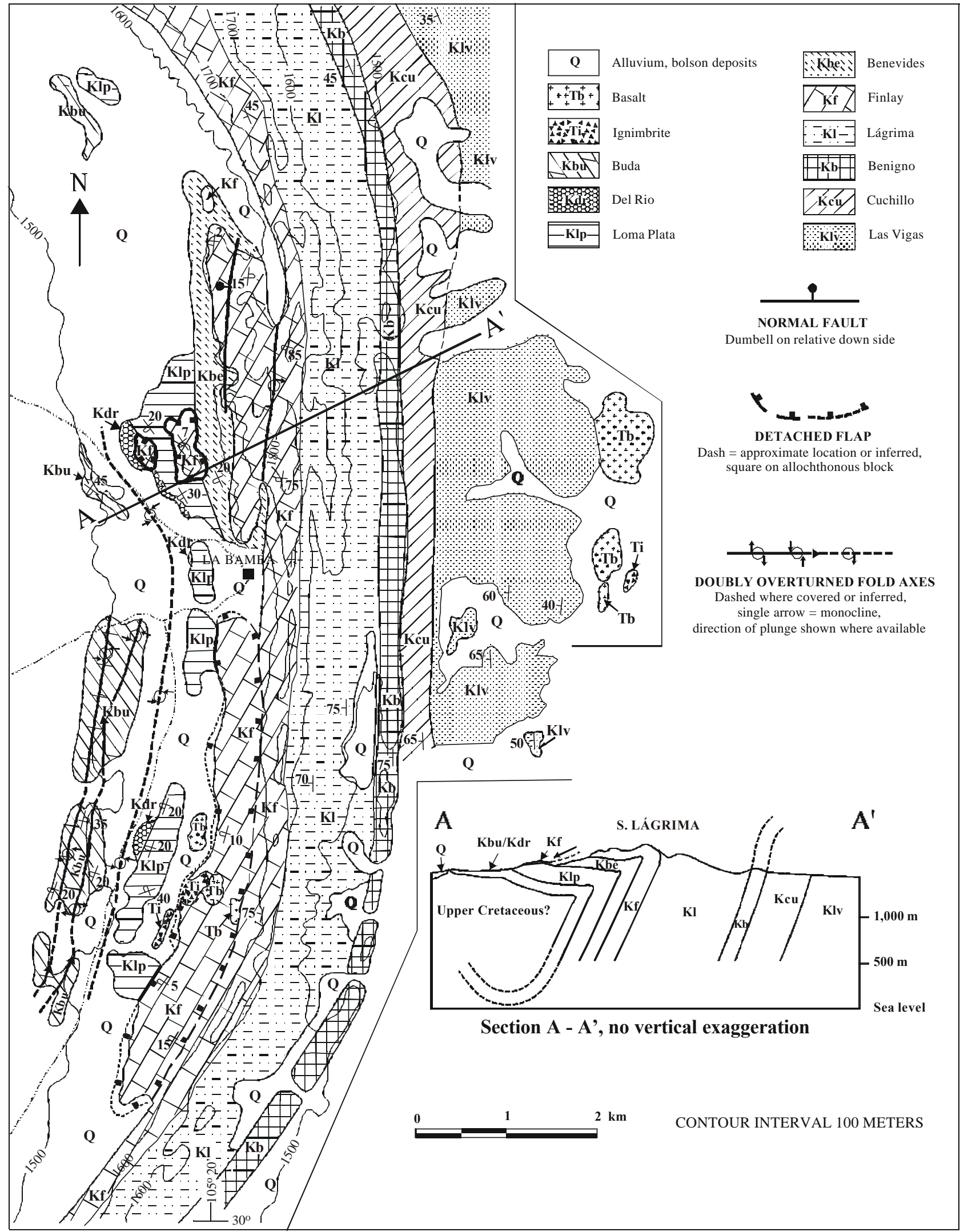

Figure 17. Map with structure section showing geology of part of southern Sierra Lágrima (after Haenggi, 1966). Structure section shows overturned gravity-induced structures (flap and detached flaps) west of crest of Sierra Lágrima. Evidence for time of flap formation is Oligocene? ignimbrite (Ti) overlying Cretaceous limestone (Kf), on detached flap, about 3.5 kilometers south of La Bamba (flap formed after Laramide deformation and prior to emplacement of Oligocene? ignimbrite). 


\subsubsection{Flaps and associated structures}

Subaerial deformation of resistant limestone beds under the influence of gravity produced an overturned monocline and slide blocks in the vicinity of La Bamba (Figure 17) and a slide block east of Sierra Ventana (Figure 1). Gries (1980) described an $8 \mathrm{~km}$-long flap on the eastern limb of a large anticline in the Sierra de la Parra Area and his map (Gries, 1970) of Sierra de la Parra Area is interpreted to show an additional large flap.

South of La Bamba, ignimbrite (Ti) and basalt (Tb) rest on a detached block of overturned Finlay Limestone (Kf). The probable age of the ignimbrite is Oligocene (28 to $32 \mathrm{Ma}$ ?) and the fold on which the flap at $\mathrm{La}$ Bamba formed is Laramide. Therefore development of the flap-slide complex near La Bamba was subsequent to Laramide folding and prior to Oligocene volcanism.

East of the southern part of Sierra Ventana, a large $(2,700 \times 600 \mathrm{~m})$ irregular-shaped outcrop of overturned Loma Plata Limestone forms a prominent cuesta above outcrops of Ojinaga Formation and pediment gravel. The overturned limestone dips about $15^{\circ}$ westward and may be underlain by a thin band of the Del Rio Formation (basis for determination of overturning). The attitude of the Loma Plata is in sharp contrast with near-vertical beds of Loma Plata on the eastern flank of the Fresnos anticline (Sierra Ventana) to the west. This is interpreted as an allochthonous block that has slid onto the Ojinaga Formation off a flap that developed on the east flank of the anticline. The structure cannot be dated, but it is assumed to be coeval with the flap structures around La Bamba.

Haenggi (1966) mapped several relatively small gravity slides that are not associated with flap structures: 1) southern Sierra Pilares near the head of Benigno Bolson (Figure 1); and 2) Cañón de Navarrete (Figure 13). The slide(s) in the Cañón de Navarrete area occurred after deposition and tilting of Oligocene volcanic rocks because in one area Finlay Limestone was emplaced over the younger rocks (Figure 13).

Gries (1980) described a structure in the Sierra de la Parra as: "A flap $8 \mathrm{~km}$ long occurs on the east limb of the Porvenir-Gaitán anticline" (shown as Sierra Grande anticline on map of Sierra de la Parra Area, Gries, 1970). The north end of the flap is bounded by a tear fault and shows a flap rotation of $180^{\circ}$, such that the limestones involved are upside down. Gries could not determine the time of flap formation. The map of Sierra de la Parra by Gries (1970) shows a 12- to 13-km long outcrop of overturned Loma Plata Limestone on the eastern flank of the southern part of the Porvenir-Gaitán anticline (not the same structure as described above). Overturned dips of as much as $33^{\circ}$ are mapped in the Loma Plata ( $157^{\circ}$ overturning) of the flap and formations toward the axial trace of the anticline are upright with average dips (normal) of about $20^{\circ}$. The northernmost end of the Loma Plata Limestone outcrop is onlapped by a Tertiary (probable Oligocene) tuff formation. This structure is readily interpreted as a flap of Loma Plata
Limestone that formed during the interval between termination of Laramide folding and deposition of the tuffs, coeval with the detached flap near La Bamba described previously.

\subsection{Mapped collapse structures}

Collapse structures have deformed Tertiary volcanic and associated rocks, and some Cretaceous formations in areas of diapiric intrusion along Cañón de Navarrete and Arroyo Cuatralbo (D and E, Figure 8). The Cañón de Navarrete structure will be described in some detail; the history of the Arroyo Cuatralbo structure is similar. The basic interpretation of these structures is that the evaporite mass (probably mostly salt) was eroded away rapidly (possibly as it was intruded) by groundwater solution and mechanical processes. Incompetent rock adjacent to the diapirs was eroded more rapidly than resistant beds, so that blocks of resistant beds broke loose and migrated downslope onto exposed evaporites. Figure18 shows a map and cross section of the resultant structure in the western part of Cañón de Navarrete. At some stage during development of the structures, Tertiary rocks were deposited in central topographic lows and then participated in later stages of the collapse (see Figure 13). After development of topographic lows over the diapirs, tilting of adjacent blocks triggered lowangle normal faults within incompetent formations, and beds adjacent to the collapse moved toward it, possibly over some blocks previously foundered in evaporites ( $c f$. the gravity slides west of Cerro La Abuja, Figure 13).

This hypothesis explains all observed relations but a major problem still exists. Are synclinal structures parallel to the diapir edges ("rim synclines") Laramide features that formed during diapiric intrusion or are they part of the collapse? The answer may be that they are both; i.e., they initially developed during Laramide diapir intrusion as relatively gentle "rim synclines" that were amplified during post-orogenic collapse.

The postulated sequence of events that lead to the present structure along the western part of Arroyo Navarrete (Figures 13, 14 and 18) is:

1) Tear faulting and diapiric intrusion of evaporites and beds of the Navarrete Formation into younger formations during the Laramide orogeny.

2) Erosion of evaporites initiated collapse along the crest of the diapir. Blocks of Finlay, middle member of the Cox, and Benigno formations detached south of the Pinosa syncline. All slid toward a developing topographic low that and eventually foundered into the evaporite diapir.

3) Ignimbrite and andesite (included in $\mathrm{Tv}$ ) and conglomerate ( $\mathrm{Tcg}$ ) were deposited in topographic low south of Pinosa syncline and immediately foundered into evaporites. A K-Ar date for the ignimbrite is $28.5 \pm$ 1.4 Ma (Gries, 1980).

4) Northeastern part of northwestern Sierra de la 


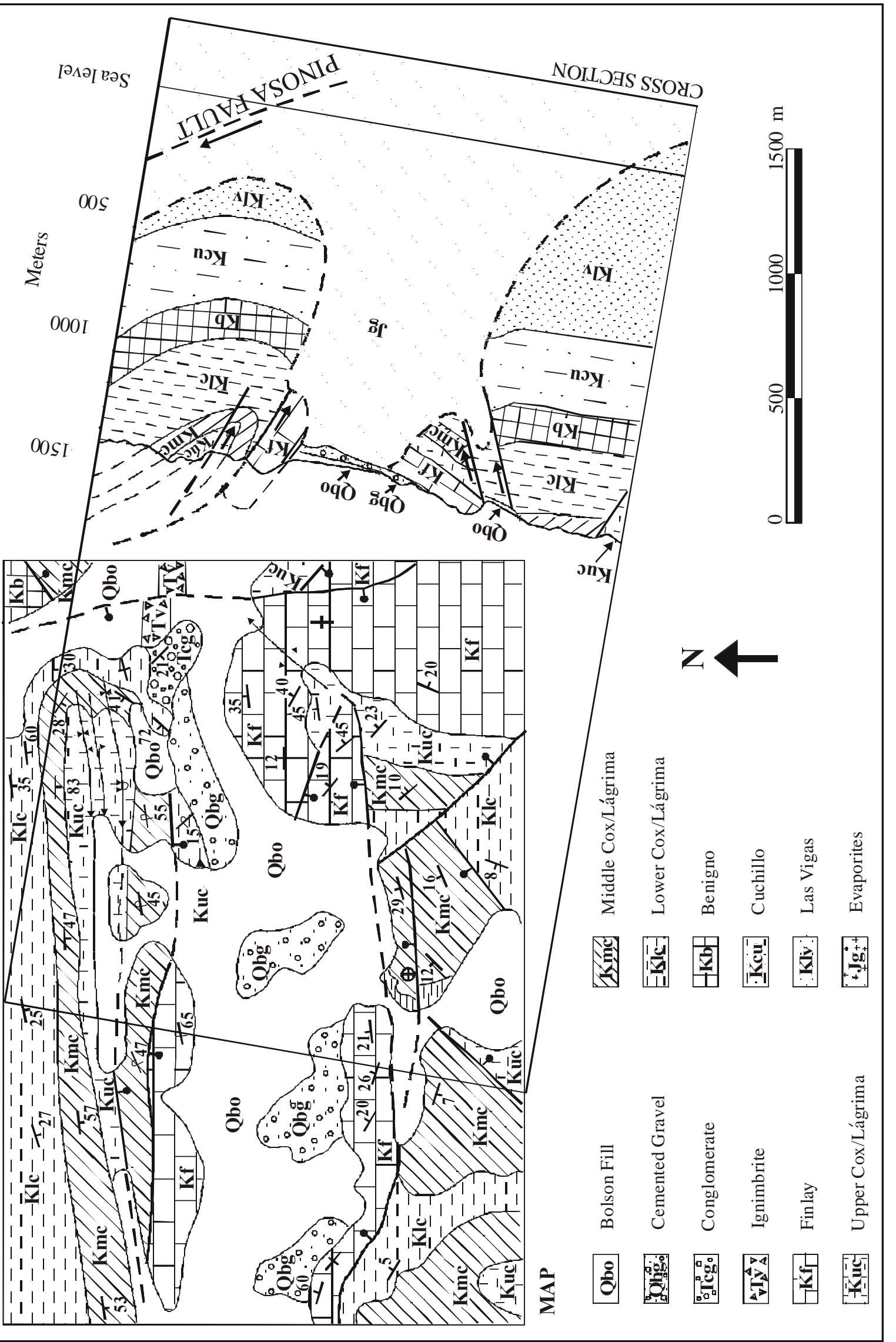

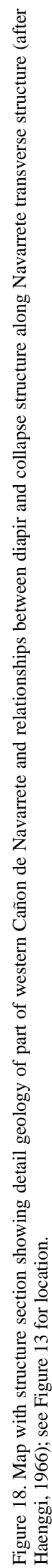


Parra tilted toward the collapse feature, and beds above the Benigno Formation slid over the foundered units. Direction of slide was perhaps southeastward into topographic low along the axis of evaporite-cored $\mathrm{La}$ Parra anticline.

5) Initiation or reactivation of faults trending northeast to north in northeastern part of northwestern Sierra de la Parra; faults offset the surface of sliding and one cut across the collapse feature (offset the ignimbrite),

6) Structure stabilized and Cenozoic bolson fill deposited unconformably over collapse feature.

7) Erosion cut deeply into exposed beds.

\subsubsection{Speculative collapse structures}

Tilted Tertiary/Quaternary bolson deposits north of Sierra de Alambre (Figure 1), between Indian Hot Springs (on the Rio Grande at the southwestern tip of the Quitman Mountains), and the "foothills of Sierra de los Pinos" (Sierra de las Vacas of Figure 1) are mapped and described by Bell (1963). North of Cerrro Carrizalillo (Figure 1) the Tertiary/Quaternary Conchos gravels locally dip as much as $20^{\circ}$ (Bridges, 1964c). King and Adkins (1946) reported that Conchos gravels, in the same general area, appear to be faulted with no explanation (perhaps observation of dipping Conchos gravels?). Bridges (1962) and Bell (1963) explained the dipping beds in their areas as effects of late Tertiary/Quaternary normal faulting. Both areas are located in JurassicNeocomian evaporite basin areas and it is suggested that tilting is related to solution of evaporites and subsequent collapse of overlying sediments.

Southwest of Indian Hot Springs, Bell (1963) measured an incomplete 800-m section of deformed bolsonfill deposits that underlie the Fort Hancock Formation (early Pleistocene, probable Nebraskan, to late Pliocene? according to Strain, 1980). The deposits are folded into an asymmetric syncline that has its axis about $1,000 \mathrm{~m}$ west of and parallel to a normal fault bounding the southern Quitman Mountains (Figure 1, see Figure 16 for location of fault). Dips of 20 to $35^{\circ}$ (east) occur on the steeper western flank of the syncline (east-facing monocline). Aspect of the structure is similar to the collapse structure in Cañón de Navarrete and it may have a similar origin. Normal faulting along the western front of the Quitman Mountains may also contribute to and complicate deformation of the bolson deposits. Timing of the deformation is unknown but if Bell is correct in his estimate of age of the bolson deposits (post-Miocene) and structural interpretation, it is probably pre-deposition of the early to middle Pleistocene Camp Rice Formation; i.e., Pliocene - early Pleistocene.

Support for this evaporite solution-collapse theory is that the area of collapse is located on the crest of the evaporite-cored structure west of the Quitman Mountains (Figure 10) and from the chemistry of the thermal waters at Indian Hot Springs. Henry (1979) reported that water from the springs contains $8,000 \mathrm{mg} / \mathrm{L}$ total dissolved solids (considerably higher than other thermal waters of the region) and concludes that the major source of dissolved ions is solution of evaporites. Atomic $\mathrm{Na} / \mathrm{Cl}$ ratios of the waters range from 1.19 to 1.26 (considerably less than ratios for other thermal water in the region) suggesting that halite (atomic $\mathrm{Na} / \mathrm{Cl}$ ratio 1) is present in the evaporite section. The chemical data indicates that the spring water has been in contact with evaporites; support for the postulated evaporite-cored anticline and a favorable environment for formation of solution-collapse structures.

The Conchos gravels have not been studied in any detail but they do occur in an area that is probably involved in evaporite tectonism (see Haenggi, 2001, Placer de Guadalupe-Carrizalillo discussion and Figure 7). Tertiary normal faults affecting the gravels have been suggested but not recognized (King and Adkins, 1946; Bridges, 1962). Evaporite solution and collapse of overlying rocks similar to that postulated at Indian Hot Springs, Cañón de Navarrete and Arroyo Cuatralbo seems a viable explanation for the dip of the Conchos gravels.

\subsection{Volcanism and igneous intrusion}

Along the eastern margin of the Chihuahua trough Oligocene (28-38 Ma) calderas in the Quitman Mountains, Eagle Mountains, Van Horn Mountains, Chinati Mountains and Sierra Rica area (San Carlos and Santana calderas) are described by Henry and Price (1984). Significantly neither major calderas nor major eruptive centers are recognized within the trough and all of the recognized calderas along the eastern margin are located on or at the margin of late Paleozoic uplifts (Diablo Plateau and Ojinaga area "high" of Haenggi, 2001). Calderas and/or volcanic centers are also present near the western boundary of the Chihuahua trough on the area of the late Paleozoic high that became the Mesozoic Aldama platform; e.g., Tomóchic volcanic center in west-central Chihuahua (McDowell et al., 1999) and Sierra Tinaja Lisa (Maugher, 1988). In the panhandle of New Mexico, immediately northwest of the Chihuahua trough, nine ash-flow tuff cauldrons are recognized in Hidalgo County (Deal et al., 1978).

Extrusive igneous rocks are present throughout the Chihuahua trough. In the northwestern area of the trough, north of Sierra Madre Occidental, they are the most commonly exposed pre-Quaternary rocks. Late Pliocene - late Pleistocene basaltic volcanoes occur in Chihuahua, southwest of Columbus, New Mexico (west of Sierra de Palomas) and are reported as far south as Laguna de Guzmán (Seager and Morgan, 1979; see Figure 1 for geographic locations). Studies of the Sierra Tinaja Lisa area, northeast of Sierra del Nido (see Figure 1 for location of S. del Nido), show three major episodes of volcanism: 1) late Eocene or older rhyolite, 2) late Eocene (37 Ma) andesite and rhyolite, and 3) midOligocene (28-33 Ma) rhyolite, mafic lavas and ash-flow 
tuff (Maugher, 1988). Most of the volcanic rocks exposed to the north, in the Chihuahua trough, probably formed during the late Eocene and mid-Oligocene periods that Maugher describes. In the eastern area of the Chihuahua trough, the previously described ignimbrites and other volcanic rocks exposed in El Cuervo Area (Haenggi, 1966) and Sierra de la Parra Area (Gries, 1970) can be correlated with Oligocene rocks of TransPecos Texas.

Small igneous intrusions are recognized at many localities within the Chihuahua trough and there are numerous mafic sills and dikes intruded into the Ojinaga Formation in several outcrop areas adjacent to the Rio Grande. There are no comprehensive studies of these rocks and any discussion of their age and origin would be speculation. They are generally interpreted as coeval with well-known Oligocene and Miocene igneous activity in adjacent areas of Trans-Pecos Texas and Sierra Madre Occidental. The only published dates for Tertiary intrusive igneous rocks in the Chihuahua trough are from PEMEX Espía-1 (ESP-1, Figure 16) where shallow andesite intrusions into Lower Cretaceous rocks are 25 to $31 \mathrm{Ma}$ (K-Ar dates; Thompson et al., 1978). Immediately south of the southeastern corner of the Chihuahua trough, granite in Sierra San Carlos (Figure 1) has been dated at $31 \mathrm{Ma}$ (Henry and McDowell, 1986).

\subsection{Faulting}

Figure 16 shows Cenozoic faulting demonstrated by field relations, subsurface structural mapping (Clint fault) and seismic interpretation. Many inferred faults (by various authors) in northeastern Chihuahua are not shown. Figure 16 also shows three possible late Oligocene-early Miocene strike-slip fault systems, Juárez, Almagre, and Caballo, described by Eguiluz de A. (1984). These postulated faults and many of the northand northwest-trending faults of Figure 16 are along elements of the regional structural fabric shown by Figure 3A and Cenozoic faults repeat every trend of late Paleozoic and Mesozoic tectonic elements of the region.

Several authors postulate that the Rio Grande rift extends into northeastern Chihuahua in various forms (e.g., Seager and Morgan, 1979; Dickerson and Muehlberger, 1994; Dickerson, 1995). Gries (1979) suggested that high-angle fault displacements of sub-evaporite rocks do not carry through extensively to the surface because of large-scale flowage of evaporites causing the masking of possible Rio Grande rift basement crustal structures. This could explain the absence of surface evidence for post-Laramide normal faults over much of the eastern part of Chihuahua and explain the concentration of recognized Tertiary-Quaternary faults along the Rio Grande edge of the Mesozoic evaporite basin. Alternatively the latest (post $7 \mathrm{Ma}$ ?) period of extensional faulting did not affect the interior region of the Chihuahua trough.

\subsubsection{Regional stress system}

Demonstrated Neogene activity of essentially all of the faults shown on Figure 16 occurred after a realignment of the regional stress system ca. 31 Ma. From analysis of orientation of dikes, veins, faults and slickensides in Trans-Pecos Texas, Henry et al. (1991) concluded that the least principal stress $\left(\sigma_{3}\right)$ was northnorthwest and the maximum principal stress $\left(\sigma_{1}\right)$ was east-northeast prior to realignment. Subsequently $\sigma_{3}$ was east-northeast and $\sigma_{1}$ was vertical (east-northeast extension). Henry et al. (1991) explained the change in stress by the approximately coeval collision of the East Pacific Rise with North America and suggested that this was a change from a convergent margin (Farallon plate) to a transform margin along the western margin of North America. The change is contemporaneous with a shift from subduction-related, continental volcanic arc magmatism to intraplate extension magmas.

Muehlberger and Dickerson (1989) suggested that the lack of igneous activity in Trans-Pecos Texas after ca. 17 Ma may represent another regional stress reorientation to maximum principal stress vertical and least principal stress west-northwest. This is consistent with Eaton's (1979) demonstration that the direction of Cenozoic extension has rotated systematically in a clockwise sense from west-southwest to west-northwest. Muehlberger and Dickerson discussed Eaton's (1979) concept that Trans-Pecos Texas [and northeastern Chihuahua] is an element of a distributed transform boundary (Southern Colorado Plateaus boundary) that has undergone oblique shear during formation of the Basin and Range province and Rio Grande rift. Eaton described the Southern Colorado Plateaus boundary as, "Coincides with a westward continuation of the enigmatic Texas Lineament," and suggested that it is an intracontinental transform with relative right-lateral motion during the past $10 \mathrm{~m} . \mathrm{y}$. This is a return to the general tectonic regime that prevailed when the Chihuahua trough formed during Jurassic time; i.e., interaction between right-lateral displacement along the Texas "zone" of Muehlberger (1980) and a north-trending ancient fabric. This interpretation is consistent with first-motion determinations for the 1931 Valentine earthquake (Dumas et al., 1980), right-slip solution accompanied by extension (maximum axis $\mathrm{S} 74^{\circ} \mathrm{W}$ ). The epicenter of the earthquake is on the northern boundary of Texas "zone" about $10 \mathrm{~km}$ northwest of Valentine, Texas (V, Figure 16).

\subsubsection{Pre-extension faulting (Pre-31Ma)}

Other than reactivation of old faults and formation of new faults, associated with post-Laramide evaporite flowage and evaporite dissolution, there is no evidence within the Chihuahua trough to suggest faulting during the interval between the end of Laramide deformation and beginning of late Tertiary/Quaternary extension. There are several clues in Trans-Pecos Texas that suggest there was some faulting during this period in the 
region. However this must be regarded with caution, because these clues are in the Trans-Pecos igneous province and observed periods of faulting may be specific to that province and not indicative of tectonism that affected the Chihuahua trough. Dickerson (1995) described the Tascotal Mesa fault (TMF, Figure 16) as having topography or being active throughout Eocene and Oligocene time. In Pinto Canyon, immediately north of the Chinati Mountains (see Figure 1 for location of Chinati Mountains), Amsbury (1957) reported reactivation of a fault during the interval between emplacement of two members of the volcanic Shely group (Ts3, $37.3 \pm$ 0.4 Ma and Ts5, 33.6 $\pm 1.1 \mathrm{Ma}$; dates from Henry and McDowell, 1986).

\subsubsection{Possible strike-slip faulting}

Eguiluz de A. (1984) postulated three major northtrending late Oligocene and/or earliest Miocene wrench fault systems in northern Mexico (Figure 16) and presented arguments based on fractures, flexures, dislocated structures, geomorphic features and alignment of plutons, to support left-lateral displacements of tens of kilometers. Evidence in the Chihuahua trough area for the Juárez fault consists of the discontinuity between the Franklin Mountains and Sierra Juárez, separation of Sierra Samalayuca and Sierra Presidio, alignment of Bouguer gravity anomalies, and exposures of preMesozoic "basement" along the fault (Franklin Mountains, Sierra Samalayuca and Sierra del Cuervo; see Figure 1 for range locations). Eguiluz de A. argued that these features show more than $10 \mathrm{~km}$ of left-lateral displacement. A case can be made for right-lateral displacement on this postulated fault in Chihuahua. Right-lateral offset could explain the anomalous presence of marine Jurassic rocks in the Grimm et al. Mobil "32-1" (32-1, Figures 8 and 16) well in New Mexico and requires only that the relationship between Sierra Samalayuca and Sierra Provincia be discarded from Eguiluz de A.'s argument; Eguiluz agrees that this is possible (personal communication, 2000). Monreal (1989) and Monreal and Longoria (1995) have also suggested strikeslip faulting in the basement of the Chihuahua trough during an uncertain time(s) between latest Cretaceous and Oligocene time.

\subsubsection{Bolsons and ranges}

Topography of northeastern Chihuahua is typical of Basin and Range but there is some doubt that Basin and Range tectonics created it, because it cannot be demonstrated that many of the "interior" bolsons and ranges, especially in the eastern area of the Chihuahua tectonic belt (e.g., Bolsón El Cuervo) are bounded by Basin and Range normal faults. A more convincing case can be made for extension of the early Rio Grande rift into northeastern Chihuahua.

With the exception of the Hueco, Red Light (Red Light Draw), and Presidio bolsons, along the eastern edge of the Chihuahua tectonic belt (see Figure 16 for locations), the bolsons in Chihuahua are closed drainage systems and are accumulating sediment. As a consequence, the lack of dissection of these bolsons and exhumation of contact areas between bolsons and ranges makes it difficult, if not impossible, to define structures that control development of the bolsons. In the interior part of the eastern area of the tectonic belt, where all ranges exhibit Laramide structure, it is possible to draw structure sections that explain the geology from range to range without invoking Tertiary normal faults; e.g., Figures 10 and 12. This may also be possible in the northwestern area of the tectonic belt but the relative paucity of ranges with exposures of pre-Tertiary rocks makes drawing sections there a speculative enterprise.

Age of the oldest bolson fill in Chihuahua is unknown but evidence from Trans-Pecos Texas indicates that the oldest bolsons there developed at the onset of extensional faulting about $24 \mathrm{Ma}$ (Stevens and Stevens, 1985). In Chihuahua there is one clue that suggests late Oligocene - earliest Miocene basin development. In PEMEX Espía-1 (ESP-1, Figure 16) 25-31 Ma andesite is intruded into Lower Cretaceous rocks (Thompson et al., 1978) and one published cross section shows most of the 1,950 m of "fill" overlying Cretaceous rocks in the well as extrusive volcanic rock (López-Ramos, 1988, Figure 6) another published section shows "fill" as bolson deposits (Limón-González, 1986, Figure 16). If this section is interpreted to be either extrusive volcanic rocks or "fill" composed, in a large part, of volcanic material and assuming that the volcanic rock and/or clasts are more-or less coeval with the intrusions, it can be inferred that filling of a bolson was underway in latest Oligocene - early Miocene time. From the data in TransPecos Texas and the inferences from Espía-1, it is readily concluded that the bolsons were developing during latest Oligocene time. This is consistent with data from southern New Mexico that show inception of the Rio Grande rift 26 to 28 Ma (Seager and Morgan, 1979). Block faulting may or may not have occurred during this postulated initial period of bolson development but must have been underway shortly thereafter.

\subsubsection{Northwestern area extensional faulting}

Figure 16 suggests that the fault system west of Longitude $107^{\circ} \mathrm{W}$ in New Mexico (after Seager, 1989) is continuous with a system of faults in northwestern Chihuahua (see Figure 1 for location of northwestern area), mapped by seismic reflection methods, extending from New Mexico to Villa Ahumada, Chihuahua (TovarR. et al., 1978). Seager interpreted age of latest movement on the New Mexico faults as latest Miocene (after $10 \mathrm{Ma}$ ) and several have known displacements during the past 10,000 years (Howard et al., 1978). Representative seismic profiles across these faults in Chihuahua show that they do not affect all of the TertiaryQuaternary bolson fill section (Tovar-R. et al., 1978, Figures 14, 29 and 30). If the age of bolson fill in Chihuahua extends from Miocene to Recent, the seismic 
data can be interpreted to show a period of faulting in Miocene time that may be coeval with some of the post$10 \mathrm{Ma}$ faulting in New Mexico. There is no evidence of Holocene fault activity in this area of Chihuahua.

A seismic line (Tovar-R. et al., 1978 Figure 30) through PEMEX Moyotes-1 (MOY-1, Figure 14) shows horsts and grabens (to fill thickness of 2,700 m) below uniform, unfaulted fill that is about $600 \mathrm{~m}$ thick (Pleistocene lake deposits?). The line is readily interpreted to indicate that a period of faulting (probably Miocene) affected bolson deposits prior to deposition of the most recent bolson sequence. Extension of Miocene and Pliocene but not Quaternary Rio Grande rift faulting into the Moyotes-1 area seems justifiable. Near PEMEX Banco Lucero-1 (BL-1, Figure 16), the Figure 10 of Tovar-R. et al. shows faulting of the older fill but no pronounced horsts and grabens; the fill accumulated in a broad basin that does not seem to be bounded by faults. Another line, in the same general area, is similar (TovarR. et al., 1978, Figure 29). Interpretation of these seismic lines and a seismic structure map (Tovar-R. et al., 1978, Figure 31) indicates that the present topography of the bolsons and ranges in this area cannot be a direct consequence of late Miocene to Recent normal faulting.

Fault trends on PEMEX seismic maps north of Sierra del Nido and southwest of Villa Ahumada (Figure 16; PEMEX, personal communication, 2000) are subparallel to trends of ranges and alluvial basins but there is no obvious direct relationship to the present topography. When the southern part of this fault system, as shown by Figure 16, is compared with the Buenaventura sheet of the magnetic map of Mexico (Consejo de Recursos Minerales, 2000a, Hoja H13-7) the faults follow a pronounced northwest-trending magnetic alignment that may be caused by basement faulting. The northwesttrending magnetic pattern persists, in areas of exposure of volcanic rocks, in Sierra Madre Occidental at least as far south as Latitude $28 \mathrm{~N}$ and is not present in the Mesozoic basin area east of the Sierra Madre (Consejo de Recursos Minerales, 2000b, Hoja H13-10, and 2000c, Hoja H13-11). These relationships and faults mapped by Maugher (1988) in the nearby Sierra Tinaja Lisa area, north of Sierra del Nido (Figure 16) show that there has been post-volcanic (post $28 \mathrm{Ma}$ ) faulting in this area and that it has had an influence on distribution of bolsons and ranges but does not directly control the existing topography. The magnetic pattern suggests that this faulting may be limited to the volcanic terranes of the Sierra Madre Occidental.

\subsubsection{Bolsón El Cuervo}

Two basic and possibly mutually exclusive hypotheses (Haenggi, 1966; Gries and Haenggi, 1970) have been suggested for the structure beneath Bolsón El Cuervo (Figure 16): 1) Structure beneath fill is basically a large evaporite-cored anticline that trends north, and 2) The bolson is a graben with boundary faults covered by young, post-faulting, bolson-fill deposits. The anticlinal interpretation is advocated here. Arguments supporting the anticlinal interpretations are:

1) It is possible to interpret structure from the Sierra de los Pinos through the Sierra Cieneguilla and across the central Pilares (see Figure 1 for locations) without invoking normal faults of large displacement,

2) Along the west front of the Sierra Pinosa midway between the Cuatralbo and Navarrete transverse structures (E and D, Figure 8) the Las Vigas Formation outcrops adjacent to the bolson and beds dip toward the east (away from the bolson). There are no traces of large displacements between the mountains and bolson. Presumably the structure here is the east limb of an anticline beneath bolson fill.

3) South of Bolsón El Cuervo, the Cuchillo Parado anticline (Figure 1) has been breached and a long intermontane valley has formed along it. Geographically, the Cuchillo Parado anticline occupies the same structural position with respect to the La Mula - Sierra Blanca Range as Bolsón El Cuervo. North of Bolsón El Cuervo, Sierra del Alambre (Figure 1) is a large overturned (toward the east) anticline (Sipperly, 1967). This structure continues northward, beneath bolson fill, and is the same anticline that has the southern Quitman Mountains as its east flank (Figure 10). Structural elements of the eastern area of the Chihuahua tectonic belt trend north for long distances; e.g., La Mula - Sierra Blanca Range; it seems reasonable to postulate a continuation of the anticlinal structure southward from Sierra del Alambre through Bolsón El Cuervo to the Cuchillo Parado structure.

Perhaps a compromise between the anticlinal and graben hypotheses is indicated by the Murciélago fault (Figure 16), an apparent graben-bounding fault, with demonstrated displacement after emplacement of Oligocene ignimbrite. Basement faulting during the period of Tertiary extension in areas where evaporites are thin, as Gries (1970) postulated at the Murciélago fault, could break through to overlying sediments.

Seven PEMEX seismic lines (Tovar-R. et al., 1978) in Bolsón El Cuervo do not resolve the issue. Review of four of these north-northeast-trending lines between Sierra Lágrima and Sierra Pilares (PEMEX, personal communication, 1973) shows reverse and normal faulting affecting the oldest bolson deposits and pre-Tertiary section. One line, south of Laguna El Cuervo (Figure 1), shows a basin of fill with no apparent faulting of the fill or older rocks. Tovar-R. et al. (1978), show one of these lines and detail of a part of it, both included in their Figure 34 (two illustrations). At the western edge of the bolson, their detailed figure shows three high angle faults, two normal and one reverse, dipping toward the bolson and offsetting the base of the fill (faults do not extend to the surface). The general appearance of fault patterns on some of the seismic lines is not unlike that shown by Schultz-Ela and Jackson (1996, Figure 9c) for suprasalt structure developed over a subsalt basement graben. 
It seems likely that the topography of Bolsón El Cuervo and adjacent ranges is not a consequence of formation of simple horsts and grabens that are developed in rocks overlying the evaporite section. Below the evaporites, it is possible (probable?) that horsts and grabens developed in the pre-evaporite basement during Miocene extensional faulting. Gries (1979) postulated that surface features common to areas of the Rio Grande rift will not be found [at the surface] in the eastern part of the Chihuahua [area of evaporite basin]. It is suggested here that this is true because the area of the evaporite basin was not a locus of basement block faulting during the most recent period of extension (post-7 Ma? until the present time).

\subsubsection{Extensional faulting along the eastern margin of the Chihuahua tectonic belt}

Extensive late Tertiary faulting has affected the area of northeastern Chihuahua along the Rio Grande from El Paso to the Big Bend (Figure 16). The Texas "zone" (Muehlberger. 1980) is the continuation of a postulated intracontinental Tertiary transform (Eaton, 1979, south edge of the "Colorado Plateaus") and comprises the Border Corridor transform complex of Dickerson (1995). As such it is the locus of complex systems of faults that have been active at various times during the past 24 m.y.

Support for the intracontinental transform interpretation and rifting is identification of transfer zones in Trans Pecos Texas adjacent to Chihuahua. Dickerson (1995) and Henry (1998) described the Tascotal Mesa fault (TMF, Figure 16) and part of a fault system along the Rio Grande at the intersection of the BrewsterPresidio county boundary with the river as a transfer zone (Figure 16). Additional support for an intracontinental transform is the abrupt termination of northtrending grabens (Mesilla Bolson, west of Franklin Mountains, portion of Hueco Bolson east of Franklin Mountains, and Salt Basin) of the Rio Grande rift of New Mexico at the northern boundary of the Texas "zone" (see Figure 16). The most recent period of faulting along the eastern margin of the Chihuahua trough is readily explained as a consequence of a transform that has been active since the onset of late Oligocene - Miocene extension.

Baker (1934) described "the great Rim Rock fault" east of the Colquitt syncline (Figure 16) as: "the fault becomes an eastward thrust with Cox sandstone of Trinity Cretaceous age thrust eastwards over Buda at the north and Eagle Ford of successively higher zones as one goes south." Oligocene volcanic rocks locally overlie Cox Sandstone in the hanging wall of the fault. Frantzen (1958) and Twiss (1959a) interpreted the surface relationships mapped by them and described by Baker as a thrust fault, beneath the Cox Sandstone of the hanging wall of the Rim Rock fault, that has been displaced by Tertiary normal faulting (thrust in footwall removed by erosion). Figure 15 shows an alternative explanation with the Rim Rock fault interpreted as a Laramide reverse fault that was reactivated as a normal fault after emplacement of Oligocene volcanic rocks. No matter what the correct explanation is, the structural relationships in this area are convincing evidence for the periodic reactivation of faults, with possible opposing senses of displacement, that is advocated throughout this paper.

The Colquitt syncline is unique in that it formed after deposition of, at least, some Oligocene volcanic rocks. Frantzen (1958) concluded that reverse displacement on the Rim Rock fault (his Smokey thrust fault) antedated formation of the Colquitt syncline that, in turn, antedated normal displacement on the Rim Rock fault. After evaluation of two hypotheses for formation of the syncline: 1) drag along faults, and 2) sinking caused by evacuation of an underlying magma chamber, Frantzen discounted both and concluded that it is a compressional feature. Muehlberger (2000, personal communications) suggested that the syncline is a pull-apart feature that developed during Tertiary right transtension; an interpretation consistent with the intracontinental transform hypothesis discussed previously.

The present topography of the Hueco Bolson, Rim Rock Country (west of Sierra Vieja) and the Presidio Bolson, along the Rio Grande, is a direct consequence of Tertiary extensional faulting (see Figure 1 for locations). Faulting in these areas has been episodic over the past 24 m.y. and it is impossible to effectively define the oldest movements on most faults. Probable Miocene faulting on the Rim Rock fault (RRF, Figures 15 and 16) was documented by DeFord and Bridges (1959) and Miocene extension was postulated during early stages of development of the Presidio Bolson (Stevens and Stevens, 1985). Baker (1934) described "earthquake cracks" showing recent movement at the head of Green River valley on trend with the Rim Rock fault. In the Hueco Bolson, Quaternary faulting is described along the Campo Grande fault (CGF, Figure 16; Collins and Raney, 1990) and late Quaternary (including Holocene) displacements occurred on the Amargosa fault (AF, Figure 16; Keaton et al., 1989). Underwood (1962) described Quaternary-age faulting that has offset pediment gravels and Pleistocene bolson fill west of the Indio Mountains (Figure 1). In the Texas portion of the Presidio Bolson, Amsbury $(1957,1958)$ mapped numerous north-trending steep normal faults that displace probable Pliocene-Pleistocene (?) bolson fill but do not affect Pleistocene-Recent terrace gravels. In Chihuahua, across the Rio Grande, Gries (1970) showed the Palo Pegado fault (PPF, Figure 16), Cipress fault (CF, Figure 16) and an unnamed north-trending fault along the Rio Grande as the boundary faults of the Presidio Bolson, and Haenggi (1966) described the Palo Pegado fault along the western edge of the bolson. All of these faults displace bolson fill that is probably no older than Pliocene. 


\section{Summary}

During an Oxfordian ( 159 to $\sim 156 \mathrm{Ma})$ period of relative counterclockwise rotation of the North American plate, reactivation of elements of an ancient system of intersecting zones of crustal weakness caused the Chihuahua trough to form as a pull-apart basin. The trough, located between the Diablo and Aldama platforms, occupies the site of the late Paleozoic Pedregosa basin and was an area of tectonic subsidence, at varying rates, from inception to earliest Albian time. The trough was the locus of a marine transgression during Late Jurassic time (Oxfordian?-Kimmeridgian). During Tithonian and Neocomian time, as relative basin subsidence rates decreased, extensive evaporite deposits were deposited in large areas of the eastern part of the trough. These deposits are a key for interpretation of the structural style of the Laramide inversion of the Chihuahua trough to form the Chihuahua tectonic belt.

From sometime during Neocomian time and extending into early Aptian time sedimentation kept pace with the subsidence caused by continuing activity on basinbounding and intra-basin faults. During this period, the Las Vigas lithosome, a large volume of clastic sediments deposited in fluctuating near-shore marine and terrestrial environments, accumulated in the trough. During late Aptian and early Albian time, activity of basin-bounding faults diminished and the sedimentary record shows a marine transgression. By middle Albian time, seas had advanced out of the trough onto previously emergent areas. As this advance got underway, areas along the eastern boundary of the Chihuahua trough received clastic sediments (Cox Formation) that are part of a transgressional sequence of sands recognized over wide areas in Texas. After the initial transgression, shallow water carbonate deposition was predominant in the Chihuahua trough from latest early Albian through middle Cenomanian time. There is no evidence that sedimentation in the trough was affected by tectonic events during this period.

The Cenomanian-Santonian? Ojinaga Formation records a sudden influx of clastic material into the Chihuahua trough. This formation is coeval with many Upper Cretaceous formations of the Western Interior Seaway of North America that contain large amounts of clastic sediments derived from Cordilleran ranges. Cordilleran source areas are inferred for the Ojinaga Formation and it is postulated that this formation is a reflection of tectonic activity in source areas to the west during the last stages of the Sevier orogeny. The San Carlos Formation conformably overlies the Ojinaga Formation and records the transition from marine to non-marine depositon in the Chihuahua trough during Campanian time.

During the Laramide orogeny (84 to $43 \mathrm{Ma}$ ) the Chihuahua trough was inverted to form the Chihuahua tectonic belt that is not considered here to be a segment of the Cordilleran thrust belt. Laramide deformation is the result of left-lateral transpressional tectonics (principal stress oriented northeast to east-northeast) and involves reactivation of fault systems of the pre-existing fabric that controlled location of the Jurassic-Aptian pull-apart basin. Timing of the onset of Laramide activity in the trough is not well defined, but dating of igneous and metamorphic rocks suggests thermal activity at the onset of Laramide time (78 to $84 \mathrm{Ma}$ ). By this time (early Campanian) the Chihuahua trough had ceased to exist and the seas were retreating toward the southeast. Latest Laramide deformation, during Eocene time (about $45 \mathrm{Ma}$ ), is documented by studies of intrusions and volcanic rocks along the north-trending boundary between the southern part of the trough and the Aldama platform.

In areas where evaporites are present (eastern area) basin-bounding normal faults were reactivated as Laramide reverse faults, with possible left-lateral components of motion, and gentle "ancestral" folds formed. As deformation continued, evaporite flow toward anticlinal crests amplified folds and, in areas of withdrawal, caused extensional faulting. Thrust faults (principally toward the Diablo Platform) developed as folds, were detached along basin margins and evaporite diapirs formed at structural discontinuities, e.g. tear faults. Studies of Laramide shortening in the eastern area of the Chihuahua tectonic belt indicate that overall shortening ranges from $5 \%$ to $24 \%$; about $10 \%$ shortening seems typical for Laramide deformation. This is considerably less than the $50 \%$ or more shortening typical of thrust belts and is consistent with shortening in inverted basins that are internal to continental margins.

In the northeastern area of the trough, where Tithonian-Neocomian evaporites are not recognized, the structure reflects northeast-southwest oriented compression and includes relatively minor southwest-directed thrusting toward and onto the Jurassic Aldama platform (greater extent than the Cretaceous platform). Paleozoic formations are involved in the thrusts and all thrusting can be interpreted as a consequence of basement faulting, including probable left-lateral wrenching along west-northwest trending faults, rather than the regionalscale décollement characteristic of thrust belts.

Post-Laramide tectonic activity includes a continuation of evaporite tectonism, gravity tectonics, scattered igneous intrusion, minor volcanism, possible strike-slip faulting, and late Oligocene - Miocene to Quaternary block faulting. In the eastern area of the Chihuahua trough, erosion, after formation of Laramide structure and before emplacement of Oligocene (32.3 to $28 \mathrm{Ma}$ ) volcanic rocks, created a topography that was similar to that of the present day. During this interval gravityinduced flaps and detached flaps developed on the flanks of several large anticlines. Collapse structures, related to evaporite solution, have deformed Tertiary and Cretaceous formations in areas of diapiric intrusion along tear fault zones.

Other than probable faulting associated with 
evaporite flow and the formation of gravity-induced structures (flaps), there is scant evidence within the Chihuahua trough to suggest what may have happened during the interval between the end of Laramide deformation and the beginning of Tertiary-Quaternary extension. Relationships between geomorphic features, alignment of intrusions and apparent offsets of stratigraphic units have been interpreted to indicate wrench faulting during this period.

Demonstrated Neogene activity of mapped faults occurred after a realignment of the regional stress system from east-northeast compression to east-northeast extension ca. $31 \mathrm{Ma}$. Initial normal faulting was probably coeval with the inception of block faulting in TransPecos Texas (ca. $24 \mathrm{Ma}$ ). Faults in the northwestern part of the trough adjacent to New Mexico are interpreted as active during Miocene time and are probably coeval with post-10 Ma activity of faults in the Rio Grande rift. Seismic and surface mapping north of the Sierra del Nido show a system of Miocene (post $28 \mathrm{Ma}$ ) normal faults that has had an influence on the distribution of bolsons and ranges, but does not directly control existing topography. With the exception of the area immediately adjacent to the Diablo Platform, direct control of topography by Neogene and/or Quaternary faulting cannot be demonstrated in the Chihuahua trough.

Extensive Neogene and some Quaternary faulting has affected the area of the Chihuahua trough, immediately adjacent to the Rio Grande between El Paso and the Big Bend. This area is a continuation of a postulated intercontinental transform along the southern edge of the Colorado Plateau and is the locus of faulting related to right transtension. The present topography of the Hueco Bolson, area between the Sierra Vieja and Sierra Pilares, and the Presidio Bolson is a direct consequence of Tertiary extensional faulting. Faulting in these areas has been episodic over the past $24 \mathrm{~m}$.y. and it is impossible to effectively define the oldest movements on most faults.

\section{References}

Adkins, W.S., 1933, The Mesozoic systems of Texas, in The Geology of Texas; v. I, Stratigraphy: Texas Bureau of Economic Geology, Bulletin 3232, p. 239-518.

Albritton, C.C., Smith, J.F.Jr., 1965, Geology of the Sierra Blanca area, Hudspeth County, Texas: United States Geological Survey, Professional Paper 479, $131 \mathrm{p}$.

Almazán-Vázquez, E., Palafox-Reyes, J.J., 2000, Secuencia samítica del Jurasico Tardío con amonitas del género Subdichotomoceras (Kimmeridgiano) expuesta al oriente de Arivechi, Sonora México: Cuarta Reunión sobre la Geología del Noroeste de México y Areas Adyacentes: Universidad Nacional Autónoma de México, Instituto de Geología, Estación Regional del Noroeste, Libro de Resúmenes, Publicaciones Ocasionales núm. 2, p. 1-2.

Amsbury, D.L., 1957, Geology of Pinto Canyon area, Presidio County, Texas: University of Texas at Austin, Ph.D. dissertation, 203 p.

Amsbury, D.L., 1958, Geology of the Pinto Canyon area, Presidio County, Texas: Texas Bureau of Economic Geology, Quadrangle
Map No. 22.

Araujo-Mendieta, J., Casar-González, R., 1987, Estratigrafía y sedimentología del Jurasico Superior en la Cuenca de Chihuahua, norte de México: Revista del Instituto Mexicano del Petróleo, 19, (1), 6-29.

Baker, C.L., 1934, Major structural features of Trans-Pecos Texas, in The Geology of Texas; Volume II, Structural and Economic Geology: The University of Texas Bulletin, No. 3401, p. 137214.

Barnes, V.E., Eifler, G.K.Jr., 1976, Geologic Atlas of Texas, Pecos Sheet: Texas Bureau of Economic Geology, scale 1:250,000.

Basset, K., Busby, C., 1997, Intra-arc strike-slip basins in the Late Jurassic southern Cordillera: Structural and climatic controls on deposition: Geological Society of America, Abstracts with Programs, 29, A-201.

Beauvais, L., Stump, T.E., 1976, Corals mollusks, and paleogeography of Late Jurassic strata of the Cerro Pozo Serna, Sonora, Mexico: Palaeogeography, Palaeoclimatology, Palaeocology, 19, 275301.

Bell, J.J., 1963, Geology of the foothills of Sierra de los Pinos, northern Chihuahua, near Indian Hot Springs, Hudspeth County, Texas: University of Texas at Austin, M.A. thesis, 83 p.

Berg, E.L., 1969, Geology of the Sierra Samalayuca, Chihuahua, Mexico, in The Border Region: New Mexico Geological Society, $20^{\text {th }}$ Field Conference Guidebook, 176-181.

Berge, T.B., 1982, Structural evolution of the northeastern Chihuahua Tectonic Belt, in Powers, R.B. (ed.), Geologic Studies of the Cordilleran Thrust Belt, Volume I: Rocky Mountain Association of Geologists, 451-457.

Bilodeau, W.L., Kluth, C.F., Vedder, L.K., 1987, Regional stratigraphic, sedimentologic and tectonic relationships of the Glance Conglomerate in southeastern Arizona, in Dickinson, W.R., Klute, M.A. (eds.), Mesozoic Rocks of Southern Arizona and Adjacent Areas: Arizona Geological Society Digest, 18, 229256.

Braithwaite, P., 1958, Cretaceous stratigraphy of northern Rim Rock Country, Trans-Pecos Texas: University of Texas at Austin, M.A thesis, $95 \mathrm{p}$.

Bridges, L.W., 1962, Geology of the Mina Plomosas area, Chihuahua, Mexico: University of Texas at Austin, Ph.D. dissertation, 240 p.

Bridges, L.W., 1964a, Stratigraphy of Mina Plomosas-Placer de Guadalupe area, in Geology of Mina Plomosas-Placer de Guadalupe area, Chihuahua, Mexico: West Texas Geological Society, Publication 64-50, 50-59.

Bridges, L.W., 1964b, Paleozoic high inferred from conglomerate outcrops composed of Precambrian metasediments in northeastern Chihuahua, Mexico (a progress report), in Geology of Mina Plomosas-Placer de Guadalupe area, Chihuahua, Mexico: West Texas Geological Society, Publication 64-50, 85-92.

Bridges, L.W., 1964c, Reconnaisance geologic map, Minas PlomosasPlacer de Guadalupe area, Chihuahua, Mexico, in Geology of Mina Plomosas-Placer de Guadalupe area, Chihuahua, Mexico: West Texas Geological Society, Publication 64-50, plate.

Brown, M.L., Dyer, R., 1987, Mesozoic geology of northwestern Chihuahua, Mexico, in Mesozoic Rocks of Southern Arizona and Adjacent Areas: Arizona Geological Society Digest, 18, 381394.

Burchfiel, B.C., Davis, G.A., 1975, Nature and controls of Cordilleran orogenesis southwestern United States; Extensions of an earlier synthesis: American Journal of Science, 275-A, 363-395.

Burckhardt, C. 1930, Etude synthétique sur la Mésozoïque Mexicain: Société Paléontologique Suisse, Mémoire 49 et 50, 280 p.

Burrows, R.H., 1909, Geology of northern Mexico: Mining and Scientific Press, v. 99, no. 9 (whole no. 2562, 28 Aug.), p. 290-294; continued as "Geology of northeastern Mexico," in no. 10 (4 Sept.), p. 324-327.

Busby-Spera, C.J., Kokelaar, B.P., 1991, Controls of the Sawmill Canyon fault zone on Jurassic magmatism and extension/transtension in southern Arizona: Geological Society of America, Abstracts with Programs, 23, A-250.

Calmus, T., Pérez-Segura, E., Stinnesbeck, W., 1997, La structuration de la marge pacifíque nordamericaine et du "terrane" Caborca; 
apports de la découverte d'une faune du Jurassique Inférieur et Moyen dans la série de Pozo Serna (Sonora Mexique): Comptes rendus de l'Académie des Sciences (Paris), Sciences de la Terre et des planétes/Earth and Planetary Sciences, 325, 257-263.

Campbell, D.H., 1970, Depositional environments of the Mountain facies of the Yucca Formation southern Quitman Mountains Hudspeth County, Texas, in Geology of the Southern Quitman Mountains Area, Trans-Pecos Texas: Permian Basin Section Society of Economic Paleontologists and Mineralogists, Publication 70-12, 70-75.

Cannon, R.L., 1940, Section encountered in the Krupp wells, Hudspeth County, Texas: American Association of Petroleum Geologists, Bulletin, 24, 1699.

Cantú-Chapa, A., 1970, El Kimeridgiano Inferior de Samalayuca, Chihuahua: Revista del Instituto Mexicano del Petróleo, 11(3), 4044.

Cantú-Chapa C.M., Sandoval-Silva, R., Arenas-Partida, R., 1985, Evolución sedimentaria del Cretácico Inferior en el norte de México; Revista Instituto Mexicano del Petróleo, 17(2), 14-37.

Cather, S.M., Chapin, C.E., 1990, Paleogeographic and paleotectonic setting of Laramide sedimentary basins in the central Rocky Mountain region; alternative interpretations and reply: Geological Society of America, Bulletin, 102, 256-260.

Charleston, S., 1981, A summary of the structural geology and tectonics of the state of Coahuila, Mexico, in Lower Cretaceous Stratigraphy and Structure, Northern Mexico: West Texas Geological Society, Publication 81-74, 28-36.

Collins, E.W., Raney, J.A., 1990, Description and Quaternary history of the Campo Grande fault of the Hueco basin, Hudspeth County and El Paso counties, Trans-Pecos Texas: Texas Bureau of Economic Geology, draft report, $61 \mathrm{p}$.

Coney, P.J., 1976, Plate tectonics and the Laramide orogeny: New Mexico Geological Society, Special Publication 6, 5-10.

Consejo de Recursos Minerales, 2000a (printed to order), Buenaventura, Hoja H13-7, Carta magnética de campo total reducido al polo, 1:250,000

Consejo de Recursos Minerales, 2000b (printed to order), Chihuahua, Hoja H13-10, Carta magnética de campo total reducido al polo, $1: 250,000$

Consejo de Recursos Minerales, 2000c (printed to order), Delicias, Hoja H13-11, Carta magnética de campo total reducido al polo, $1: 250,000$.

Corbitt, L.L., 1988, Tectonics of thrust and fold belt of northwestern Chihuahua: New Mexico Geological Society, Southwestern New Mexico, $39^{\text {th }}$ Field Conference Guidebook, 67-70.

Córdoba, D.A., 1969, Mesozoic stratigraphy of northeastern Chihuahua, Mexico, in The Border Region: New Mexico Geological Society, $20^{\text {th }}$ Field Conference Guidebook, 91-101.

Córdoba, D.A., Rodríguez-Torres, R., Guerrero-García, J., 1970, Mesozoic stratigraphy of the northern portion of the Chihuahua Trough, in The Geologic Framework of the Chihuahua Tectonic Belt; Symposium in honor of Professor Ronald K. DeFord: West Texas Geological Society and The University of Texas at Austin, 83-97.

Davis, G.H., 1979, Laramide folding and faulting in southeastern Arizona: American Journal of Science, 279, 543-569.

Deal, E.G., Elston, W.E., Erb, E.E., Peterson, S.L., Reiter, D.E., Damon, P.E., Shsfiqullah, M., 1978, Cenozoic volcanic geology of the Basin and Range Province in Hidalgo County, New Mexico, in The Land of Cochise: New Mexico Geological Society, $29^{\text {th }}$ Field Conference Guidebook, 219-229.

DeFord, R.K., 1958a, Cretaceous platform and geosyncline, Culbertson and Hudspeth counties, Texas: Van Horn, Texas, Society of Economic Paleontologists and Mineralogists, Permian Section, Guidebook 1958 Field Trip, 90 p.

DeFord, R.K., 1958b, Tertiary formations of the Rim Rock Country, Presidio County, Trans-Pecos Texas: Texas Journal of Science, 10, 1-37 (Reprinted as Texas Bureau of Economic Geology, Report of Investigations No. 36).

DeFord, R.K., Bridges, L.W., 1959, Tarantula Gravel, northern Rim Rock Country, Trans-Pecos Texas: Texas Journal of Science, 11, 286-295.
DeFord, R.K., Haenggi, W.T., 1970, Stratigraphic nomenclature of Cretaceous rocks in northeastern Chihuahua, in The Geologic Framework of the Chihuahua Tectonic Belt; Symposium in honor of Professor Ronald K. DeFord: West Texas Geological Society and The University of Texas at Austin, 175-196.

DeJong, H.W., Addy, S.K., 1992, Broad view indicates hydrocarbon potential low in far West Texas; Trans-Pecos Texas-2 (Conclusion): Oil and Gas Journal, January 27, 97-102.

Denison, R.E., Burke, W.H. Jr., Hetherington, E.A. Otto, J.B., 1970, Basement rock framework of parts of Texas, southern New Mexico and northern Mexico, in The Geologic Framework of the Chihuahua Tectonic Belt; Symposium in honor of Professor Ronald K. DeFord: West Texas Geological Society and The University of Texas at Austin, 3-14.

Díaz, T., 1956, Guía del Campo, en Estratigrafía Mesozoica y Tectónica de la Sierra de Chihuahua; Pérmico de Placer de Guadalupe, Chih.; Geohydrología de la Región Lagunera; Estratigrafía Mesozoica y Tectónica de la Sierra Madre Oriental entre Mapimí, Dgo. y Monterrey, N.L.: Congreso Geológico Internacional, Excursión A-13, 23-32.

Díaz, T, 1964, Interpretación esquematica de la estructura perforada por el pozo de exploración Chapo No. 2, en Geology of Mina Plomosas-Placer de Guadalupe area, Chihuahua, Mexico: West Texas Geological Society, Publication 64-50, 15.

Dickerson, P.W., 1985, Evidence for Late Cretaceous-early Tertiary transpression in Trans-Pecos Texas and adjacent Mexico, in Structure and Tectonics of Trans-Pecos Texas: West Texas Geological Society, Publication 85-81, 185-194.

Dickerson, P.W., 1995, Tascotal Mesa transfer zone, Rio Grande rift of west Texas (Presidio, Brewster counties); A structural, mechani$\mathrm{cal}$, and thermal characterization: University of Texas at Austin, Ph.D. dissertation, $189 \mathrm{p}$.

Dickerson, P.W., Muehlberger, W.R., 1994, Basins in the Big Bend segment of the Rio Grande rift, Trans-Pecos Texas, in Keller, G R., Cather, S.M. (eds.), Basins of the Rio Grande Rift: Structure, Stratigraphy and Tectonic Setting: Geological Society of America, Special Paper 291, 283-297.

Dickinson, W.R., Lawton, T.F., 2000, Sandstone petrofacies and tectonic setting of the Bisbee Basin (USA-Mexico): Cuarta Reunion sobre la Geología del Noroeste de México y Areas Adyacentes, Libro de Resúmenes, Universidad Nacional Autónoma de México, Instituto de Geología, Estación Regional del Noroeste, Publicaciones Oc asionales No. 2, p. 26-27.

Dickinson, W.R., Klute, M.R., Swift, P.N., 1986, The Bisbee Basin and its bearing on late Mesozoic peleogeographic and paleotectonic relations between the Cordilleran and Caribbean regions, in Abbott, P.L. (ed.), Cretaceous Stratigraphy Western North America, Society of Economic Paleontologists and Mineralogists, Pacific Section, Book 46, p. 51-62.

Dirección General de Estudios del Territorio Nacional (DETENAL), 1976, Carta Topográfica de los Estados Unidos Mexicanos, Hoja H13A89, El Cuervo, 1:50,000.

Dirección General de Estudios del Territorio Nacional (DETENAL), 1977, Carta Topográfica de los Estados Unidos Mexicanos, Hoja H13A88, San Pablo, 1:50,000.

Dirección General de Estudios del Territorio Nacional (DETENAL), 1978, Carta Topográfica de los Estados Unidos Mexicanos, Hoja H13B81, San Antonio El Bravo, 1:50,000.

Dirección General de Estudios del Territorio Nacional (DETENAL), 1978, Carta Geológica de los Estados Unidos Mexicanos, Hoja H13D42, Potrero Del Llano, 1:50,000.

Dirección General de Estudios del Territorio Nacional (DETENAL), 1979, Carta Geológica de los Estados Unidos Mexicanos, Hoja H13D32, Alamo Chapo, 1:50,000 and Hoja H13D41, Las Animas, 1:50,000.

Drewes, H., 1978, the Cordilleran orogenic belt between Nevada and Chihuahua: Geological Society of America, Bulletin, 89, 641657.

Drewes, H., 1981, Tectonics of southeastern Arizona: United States Geological Survey, Professional Paper 1144, 96 p.

Drewes, H., 1988, Development of the foreland zone and adjacent terranes of the Cordilleran orogenic belt near the U.S.-Mexican 
border, in Schimdt, C.J., Perry, W.J., Jr. (eds.), Interaction of the Rocky Mountain foreland and the Cordilleran thrust belt, Geological Society of America, Memoir 171, p. 447-463.

Drewes, H., 1991a, Description and development of the Cordilleran orogenic belt in the southwestern United States and northern Mexico: United States Geological Survey, professional Paper $1512,92 \mathrm{p}$.

Drewes, H., 1991b, Geologic map of the Big Hatchet Mountains, Hidalgo County, New Mexico: United States Geological Survey, Miscellaneous Investigations Series Map I-2144.

Drewes, H., Dyer, R., 1993, Geologic map and structure sections of the Sierra Juárez, Chihuahua, Mexico: United States Geological Survey, Miscellaneous Investigations, Map I-2287.

Dumas, D.B., Dorman, H.J., Latham, G.V., 1980, A reevaluation of the August 16, 1931 Valentine, Texas earthquake: Seismological Society of America, Bulletin, 70, 1171-1180.

Dyer, R., (1987), First day, Part A; Road log from E Paso/Ciudad Juárez via Villa Ahumada, El Sueco to Ciudad Chihuahua, in Excursión Geológica, Libreto Guía de Caminos, Sociedad Geológica Mexicana, Universidad Autónoma de Chihuahua, University of Texas at El Paso, p. 2-30.

Eaton, G.P., 1979, A plate-tectonic model for Late Cenozoic crustal spreading in the western United States, in Riecker, R.E. (ed.), Rio Grande Rift: Tectonics and Magmatism, American Geophysical Union, p. 7-32.

Eaton, J., Dyer, R., Goodell, P.C., 1983, Preliminary report on the stratigraphy of Lower Cretaceous, northern Sierra Las Vacas, Chihuahua, Mexico, in Geology and Mineral Resources of North-Central Chihuahua, El Paso Geological Society 1983 Field Conference Guidebook, p. 269-274.

Eguiluz de A., S., 1984, Tectónica Cenozoica del norte de México: Asociación Mexicana de Geólogos Petroleros, Boletín, XXXVI, 43-62.

Fackler-Adams, B.N., Busby, C.J., Mattinson, J.M., 1997, Jurassic magmatism and sedimentation in the Palen Mountains, southeastern California: Implications for regional tectonic controls on the Mesozoic continental arc: Geological Society of America, Bulletin, 109, 1464-1484.

Frantzen, D.R., 1958, Oligocene folding in Rim Rock country, TransPecos Texas: University of Texas at Austin, M.A. thesis, 45 p.

Garrison, J.M., McMillan, N.J., 1999, Jurassic continental rift magmatism in northeast Mexico: Allogenic metaigneous blocks in the El Papalote evaporite diapir, La Popa basin, Nuevo Leon, Mexico, in Bartolini, C., Wilson, J.L., Lawton, T.F. (eds.), Mesozoic Sedimentary and Tectonic History of North-Central Gulf of Mexico, Geological society of America, Special Paper 340, p. 319-332.

Gilmer, A.K, 2001, Age and characterization of the Red Hills porphyry copper-molybdenum deposit, Presidio County, Texas: University of Texas at Austin, Technical Sessions abstract, 1p.

Gómez, F., 1983, Geology of Sierra del Aguila, northern Chihuahua, Mexico, in Geology and Mineral Resources of North-Central Chihuahua: El Paso Geological Society, Guidebook 1983 Field Conference, p. 261-267.

Gradstein, F.M., Agterberg, F.P., Ogg, J.C., Hardenbol, J., van Veen, P., Thierry, J., Huang, Z., 1994, A Mesozoic time scale: Journal of Geophysical Research, 99, 24,051-24,074.

Gregory, J.L., 1981, Volcanic stratigraphy and K-Ar ages of the Manuel Benavides area, northeastern Chihuahua, Mexico and correlations with the Trans-Pecos volcanic province: University of Texas at Austin, M.A. thesis, $78 \mathrm{p}$.

Gries, J.F., 1970, Geology of the Sierra de la Parra area, northeast Chihuahua, Mexico: University of Texas at Austin, Ph.D. dissertation, $151 \mathrm{p}$.

Gries, J.F., 1979, Problems of delineation of the Rio Grande rift into the Chihuahua Tectonic Belt of northern Mexico, in Riecker, R. E., (ed.), Rio Grande Rift, Tectonics and Magmatism: American Geophysical Union, p. 107-113.

Gries, J.F., 1980, Laramide evaporite tectonics along the Texasnorthern Chihuahua border, in Trans-Pecos Region, New Mexico Geological Society, $31^{\text {st }}$ First Field Conference Guidebook, p.93100 .
Gries, J.F., Haenggi, W.T., 1970, Structural evolution of the eastern Chihuahua Tectonic Belt, in The Geologic Framework of the Chihuahua Tectonic Belt: Symposium in honor of Professor Ronald K. DeFord, West Texas Geological Society and The University of Texas at Austin, p. 119-137.

Guerrero, J.C., 1969, Stratigraphy of Banco de Lucero, State of Chihuahua, in The Border Region, New Mexico Geological Society, $20^{\text {th }}$ Field Conference Guidebook, p. 171-172.

Haenggi, W.T., 1966, Geology of El Cuervo area, northeastern Chihuahua, Mexico: University of Texas at Austin, Ph.D. dissertation, $403 \mathrm{p}$.

Haenggi, W.T., 2001, Tectonic history of the Chihuahua Trough, Mexico and adjacent USA; Part I, the pre-Mesozoic setting: Boletín de la Sociedad Geológica Mexicana, Tomo LIV, 28-66.

Haenggi, W.T., Gries, J.F., 1970, Structural evolution of northeastern Chihuahua Tectonic Belt, in Geology of the Southern Quitman Mountains Area, Trans-Pecos Texas: Society of Economic Paleontologists and Mineralogists, Permian Basin Section, Publication 70-12, p. 55-69.

Handschy, J.W., 1984, A preliminary report on the geology of Sierra Cuervo near Villa Aldama, Chihuahua, Mexico, in Geology and petroleum Potential of Chihuahua, Mexico: West Texas Geological Society, Publication 84-80, p. 196-201.

Harkey, D.A., Dyer, R., 1985, Stratigraphy and structure of Sierra Asn Ignacio, Chihuahua, Mexico, in Structure and Tectonics of Trans-Pecos Texas: West Texas Geological Society, Publication 85-81, p.195-204.

Harrigan, P.I., 1995, Stratigraphic depositional environments and tectonic setting of the Broken Jug Formation (Late Jurassic?-Early Cretaceous) in the Little Hatchet Mountains, southwestern New Mexico: New Mexico State University, MS thesis, $101 \mathrm{p}$.

Harrison, J.V., Falcon, N.L., 1936, Gravity collapse structures and mountain ranges as exemplified in southwestern Iran: Geological Society of London, Quarterly Journal, 92, 91-102.

Hay-Roe, H., 1958, Geology of Wylie Mountains and vicinity, TransPecos Texas: University of Texas at Austin, Ph.D. dissertation, $226 \mathrm{p}$.

Heiken, G.H., 1966, Geology of Cerros Prietos, Municipio de Ojinaga, Chihuahua, Mexico: University of Texas at Austin, M.A. thesis, $101 \mathrm{p}$.

Hennings, P.H., 1991, Structural studies of the Chihuahua Tectonic Belt: University of Texas at Austin, Ph.D. dissertation, 117 p.

Hennings, P.H., 1994, Structural transect of the southern Chihuahua Fold Belt between Ojinaga and Aldama, Chihuahua, Mexico: Tectonics, 13, 1445-1460.

Henry, C.D., 1979, Geologic setting and geochemistry of thermal water and geothermal assessment. Trans-Pecos Texas: Texas Bureau of Economic Geology, Report of Investigations No, 96, 48 p.

Henry, C.D., 1998, Basement controlled transfer zones in an area of low-magnitude extension, eastern Basin and Range province, Trans-Pecos Texas, in Faulds, J.E., Stewart, J.H. (eds.), Accomodation Zones and Transfer Zones; The Regional Segmentation of the Basin and Range Province: Geological Society of America, Special Publication 323, p. 75-88.

Henry, C.D., McDowell, F.W., 1986, Geochronology of magmetism in the Tertiary volcanic field, Trans-Pecos Texas, in Igneous Geology of Trans-Pecos Texas: Texas Bureau of Economic Geology, Guidebook 23, p. 99-122.

Henry, C.D., Price, J.G., 1984, Variations in caldera development in the Tertiary volcanic field of Trans-Pecos Texas: Journal Geophysical Research, 89 (B10), 8,765-8,786.

Henry, C.D., Price, J.G., James, E.W., 1991, Mid-Cenozoic stress evolution and magmatism in the southern Cordillera, Texas and Mexico: Transition from continental arc to intraplate extension: Journal of Geophysical Research, 96, 13,545, 13,560.

Hill, R.T., 1901, Geography and geology of the Black and Grand prairies: United States Geological Survey, $21^{\text {st }}$ Annual Report., pt. 7, $666 \mathrm{p}$.

Howard, K.A., Aaron, J.M., Brabb, E.E., Brock, M.R., Gower, H.D., Hunt, S.J., Milton, D.J., Muehlberger, W.R., Nakata, J.K., Pflaker, G., Prowell, D.C., Wallace, R.E., Witkind, I.J., 1978, Preliminary map of young faults in the United States as a guide 
to possible fault activity: United States Geological Survey, Miscellaneous Field Studies, Map MF-916.

Humphrey, W.E., 1964, Measured section Sierra Soldado area, in Geology of Mina Plomosas-Placer de Guadalupe area, Chihuahua, Mexico: West Texas Geological Society, Publication 64-50, p. 38-41.

Imlay, R.W., 1980, Jurassic Paleobiogeography of the Conterminous United States in its Continental Setting: United States Geological Survey, Professional Paper 1062, 134 p.

Jacques-Ayala, C., 1995, Paleogeography and provenance of the Lower Cretaceous Bisbee Group in the Caborca-Santa Ana area, northwestern Sonora, in Jacques-Ayala, C., González-León, C.M., Roldán-Quintana, J (eds.), Studies on the Mesozoic of Sonora and Adjacent Areas: Geological Society of America, Special Paper 301, 79-98.

James, E.W., Henry, C.D., 1993, Pb isotopes of ore deposits in TransPecos Texas and northeastern Chihuahua, Mexico; Basement, igneous and sedimentary sources of metals: Economic Geology, $88,934-947$

Jamison, K., 1987, Petrofacies of Morita Formation (Bisbee Group), southeastern Arizona and northern Sonora, Mexico, in Dickinson, W.R., Klute, M.A. (eds.), Mesozoic Rocks of Southern Arizona and Adjacent Areas, Arizona Geological Society Digest, $18,257-262$.

Jones, B.R., 1968, Geology of southern Quitman Mountains and vicinity, Hudspeth County, Texas: Texas A \& M University, Ph.D. dissertation, $162 \mathrm{p}$

Jones, B.R., Reaser, D.F., 1970, Geology of southern Quitman Mountains, Hudspeth County, Texas: Texas Bureau of Economic Geology, Geologic Quadrangle Map No. 39.

Jones, N.W., McKee, J.W., Anderson, T.H., Silver, L.T., 1995, Jurassic volcanic rocks in northeastern Mexico; A possible remnant of a Cordilleran magmatic arc, in Jacques-Ayala, C., González-León, C.M., Roldán-Quintana, J (eds.), Studies on the Mesozoic of Sonora and Adjacent Areas: Geological Society of America, Special Paper 301, 179-190.

Keaton, J.R., Shlemon, R.J., Slemmons, D.B., Clark, D.G., 1989, The Amargosa fault: A major late Quaternary intraplate structure in northern Chihuahua, Mexico: Geological Society of America, Abstracts with Programs, p. A148.

Keith, S.B., Wilt, J.C., 1986, Laramide orogeny in Arizona and adjacent regions; a strato-tectonic synthesis: Arizona Geological Society Digest, 16, 502-554

King, R.E., Adkins, W.S., 1946, Geology of a part of the lower Conchos valley, Chihuahua, Mexico: Geological Society of America, Bulletin, 57, 275-294.

Lasky, S.G., 1947, Geology and ore deposits of the Little Hatchet Mountains, Hidalgo and Grant copunties, New Mexico: United States Geological Survey, Professional Paper 208, 101 p.

Lawton, T.F., Olmstead, G.A., 1995, Stratigraphy and structure of the lower part of the Bisbee Group, northeastern Chiricahua Mountains, Arizona, in Jacques-Ayala, C., González-León, C.M., Roldán-Quintana, J (eds.), Studies on the Mesozoic of Sonora and Adjacent Areas, Geological Society of America, Special Paper 301, 21-39.

Lawton, T.F., Garrison, J.M., McMillan, N.J., 1997, Late Jurassic transtensional borderland on the southwestern margin of North America: Geological Society of America, Abstracts with Programs, 29, p. A-200-A-201.

Lehman, T.M., 1991, Sedimentation and tectonism in the Laramide Tornillo Basin of west Texas: Sedimentary Geology, 75, 9-28.

Limón-González, M., 1986, Evaluación geológico--geoquimica de la provincia de Chihuahua: Asociación Mexicana de Geólogos Petroleros, Boletín, XXXVIII, 3-58.

López-Ramos, E., 1988, Geología y aprovechamiento integral de las perforaciónes en el altiplano Mexicano: Geomimet, 151, 84-100.

Lucas, S.G., and Lawton, T.F., 2000, Stratigraphy of the Bisbee Group (Jurassic-Cretaceous), Little Hatchet Mountains, New Mexico, in Southwest Passage; A trip through the Phanerozoic, New Mexico Geological Society, $51^{\text {st }}$ Field Conference Guidebook, p. 175194.

Mack, G.H., Clemons, R.E., 1988, Structural and stratigraphic evi- dence for the Laramide (Early Tertiary) Burro uplift in southwestern New Mexico, in Southwestern New Mexico: New Mexico Geological Society, $39^{\text {th }}$ Field Conference Guidebook, p. 5966.

Maugher, R.L., 1988, A geologic sketch of the Tinaja Lisa block, north-central Chihuahua, Mexico, in Stratigraphy, Tectonics and Resources of Parts of Sierra Madre Occidental Province, Mexico: El Paso Geological Society, Guidebook 1988 Field Conference, 217-227.

Maxwell, R.A., Dietrich, J.W., 1965, Geologic summary of the Big Bend region, in Geology of the Big Bend area, Texas: West Texas Geological Society Field Trip Guidebook 65-51, 11-33.

McDowell, F.W., Maugher, R.L., 1994, K-Ar and U-Pb zircon chronology of Late Cretaceous and Tertiary magmatism in central Chihuahua State, Mexico: Geological Society of America, Bulletin, 106, 118-132.

McDowell, F.W., Housh, T.B., Wark, D.A., 1999, Nature of the crust beneath west-central Chihuahua, Mexico, based upon $\mathrm{Sr}, \mathrm{Nd}$, and $\mathrm{Pb}$ isotopic compositions at the Tomóchic volcanic center: Geological Society of America, Bulletin, 111, 823-830.

McKee, J.W., Jones, N.W., Anderson, T.H., 1988, Las Delicias basin; A record of late Paleozoic arc volcanism in northeastern Mexico: Geology, 16, 37-40

McKee, J.W., Jones, N.W., Anderson, T.H., 1990, Stratigraphy and provenance of strata along the San Marcos fault, central Coahuila, Mexico: Geological Society of America, Bulletin, 102, 593-614.

Miller, J.P., Montgomery, A., Sutherland, P.K., 1963, Geology of part of the Sangre de Cristo Mountains, New Mexico: New Mexico Bureau of Mines and Mineral Resources, Memoir 11, 106 p.

Miller, W.D., 1975, Geology of the Cox Formation, Trans-Pecos Texas, in Geology of the Eagle Mountains and Vicinity, TransPecos Texas: Society of Economic Paleontologists and Mineralogists, Permian Basin Section, Publication 75-15, 103-112.

Milton, A.P., 1964, Geology of Cajoncito area in Municipio de Guadalupe, Chihuahua and Hudspeth County, Texas: University of Texas at Austin, M.A. thesis, $78 \mathrm{p}$.

Monreal, R., 1989, Regional stratigraphic studies of the Lower Cretaceous in northern Mexico and the southern United States: University of Texas at Dallas, Ph.D. dissertation, $371 \mathrm{p}$.

Monreal, R., 1995, Las facies marinas (Aptiano-Albiano) del Grupo Bisbee y cronocorrelativas en Sonora: México, Hermosillo, Son., Universidad de Sonora, Departamento de Geología, Boletín, 12 (1), 65-78;

Monreal, R., Longoria, J.F., 1995, Transpressional deformational pattern related to basement faults in the Mesozoic of northeastern Chihuahua: México, Hermosillo, Son., Universidad de Sonora, Departamento de Geología, Boletín, 12 (2), 17-34.

Monreal, R., Longoria, J., 1999, A revision of the Upper Jurassic and Lower Cretaceous stratigraphic nomenclature for the Chihuahua trough, north-central Mexico: Implications for lithocorrelations, in Bartolini, C., Wilson, J.L., Lawton, T.F. (eds.), Mesozoic Sedimentary and Tectonoic History of North-Central Mexico: Geological Society of America, Special Paper 340, 69-92.

Monreal, R. Longoria, J., 2000, Stratigraphy and structure of the Lower Cretaceous of Lampazos, Sonora, (northwest Mexico) and its relationship to the Gulf Coast succession: American Association of Petroleum Geologists, Bulletin, 84, 1811-1831.

Mraz, J.R., Keller, G.R., 1980, Structure of the Presidio Bolson area, Texas, interpreted from gravity data: Texas Bureau of Economic Geology, Geological Circular 80-13, 20 p.

Muehlberger, W.R., 1980, Texas lineament revisited, in Trans-Pecos Region: New Mexico Geological Society, $31^{\text {st }}$ Field Conference Guidebook, 113-121.

Muehlberger, W.R., 1992, Tectonic Map of North America, Southeast Sheet: American Association of Petroleum Geologists, 1: $5,000,000$

Muehlberger, W.R., 1996, Tectonic Map of North America, A User's Guide: American Association of Petroleum Geologists, $14 \mathrm{p}$.

Muehlberger, W.R., Dickerson, P.W., 1989, A tectonic history of Trans-Pecos Texas, in Structure and Stratigraphy of Trans-Pecos Texas: American Geophysical Union, 28th International Geo- 
logical Congress, Field Trip Guidebook T317, 35-54.

Nourse, J.A., 1995, Jurassic-Cretaceous paleogeography of the Magdalena region, northern Sonora, and its influence on the positioning of Tertiary metamorphic core complexes, in Jacques-Ayala, C., González-León, C.M., Roldán-Quintana, J (eds.), Studies on the Mesozoic of Sonora and Adjacent Areas: Geological Society of America, Special Paper 301, 59-79.

Odonne, F., Vialon, P., 1983, Analogue models of folds above a wrench fault: Tectonophysics, 99, 31-46.

Olmstead, G.A., Young, K., 2000, Late Jurassic ammonites form the northeastern Chiracahua Mountains, southeast Arizona: New Mexico Geology, 22, 1-7.

Ortega-Gutiérrez, F., Mitre-Salazar, L.M., Roldán-Quintana, J., Aranda-Gómez, J, Morán-Zenteno, D., Alaniz-Álvarez, S.A., Nieto-Samaniego, A., 1992, Carta Geológica de la Republica Mexicana, escala 1: 2,000,000: Consejo de Recursos Naturales, Universidad Nacional Autónoma de México, Instituto de Ceología, 5a. Edición.

Pálfy, J., González-León, C.M., 2000, Lower Jurassic ammonoid biostratigraphy of the Antimonio terrane, Sonora, northwestern Mexico: Cuarta Reunión sobre la Geología del Noroeste de México y Areas Adyacentes, Libro de Resumes: Universidad Nacional Autónoma de México, Instituto de Geología, Estación Regional del Noroeste, Publicaciones Ocasionales No. 2, 87-88.

Palmer, A.R. (Compiler), 1983, Decade of North American geology (DNAG), Geologic time scale: Geology, 11, 503-504.

Pearson, B.T., 1980, General survey of the oil and gas prospects of Trans-Pecos Texas, in Trans-Pecos Region: New Mexico Geological Society, $31^{\text {st }}$ Field Conference Guidebook, 271-276.

Peebles, R.G. 1991, Stratigraphic studies and microfacies analysis of Sierra Cuchillo Parado, Chihuahua, Mexico: University of Texas at Dallas, M.S. thesis, $137 \mathrm{p}$.

Ramírez-M., J.C., Acevedo-C., F., 1957, Notas sobre la geólogía de Chihuahua: Asociación Mexicana de Geólogos Petroleros, Boletín, IX, 583-772.

Rangin, C., 1977, Sobre la presencia del Jurásico Superior con amonitas in Sonora septentrional: Universidad Nacional Autónoma de México, Instituto de Geología, Revista, 1 (1), 1-4.

Reaser, D.F., 1974, Geology of Cieneguilla area, Chihuahua, Mexico: University of Texas at Austin, Ph.D. dissertation, 340 p.

Reaser, D.F., 1982, Geometry and deformational environment of the Cineguilla-Quitman range in northeastern Chihuahua, Mexico and western Trans-Pecos Texas, USA, in Powers, R.B. (ed.), Geologic studies of the Cordilleran thrust belt, v. 1: Denver, Co., Rocky Mountain Association of Geologists, 425-449.

Reyeros de Castillo, M.M., 1974, Corales del Jurásico superior de Chihuahua: Universidad Nacional Autónoma de México, Instituto de Geología, Paleontología Mexicana, no. 40, 7-43.

Reyes-Cortés, I.A., Goodell, P.C., 2000, Geologic setting and mineralization: Sierra Peña Blanca, Chihuahua, Mexico, in Cuarta Reunión Sobre la Geología del Noroeste de México y Areas Adyacentes, Estación Regional del Noroeste: Universidad Nacional Autónoma de México, Instituto de Geología, Estación Regional del Noreste, Publicaciones Ocasionales No. 2, 101.

Riggs, N.R., Haxel, G.B., 1990, The Early to Middle Jurassic magmatic arc in southern Arixzona; Plutons to sand dunes, in $\mathrm{Ge}-$ hrels, G.E., Spencer, J.E. (eds.), Geologic Excursions Arizona Geologic Excursions Through the Sonora Desert Region, Arizona and Sonora: Arizona Geological Society, Special Paper 7, 90-103.

Roberts, D.C., and Dyer, R., 1988, A preliminary report on the geology of the Cerro Panales area, east-central Chihuahua, Mexico, in Stratigraphy, Tectonics and Resources of Parts of Sierra Madre Occidental Province, Mexico: El Paso Geological Society, Guidebook 1988 Field Conference, 159-172.

Rodríguez-Torres, R., 1969, Mesozoic stratigraphy of Sierra de la Alcaparra, northeastern Chihuahua, Mexico, in The Border Region: New Mexico Geological Society, $20^{\text {th }}$ Field Conference Guidebook, 173-175.

Rodríguez-Torres, R., Guerrero-García, J.C., 1981, Hoja Villa Ahumada, 13R-a (9): Universidad Nacional Autónoma México, Instituto de Geología, Cartas Geológicas de México, serie 1:100,000,
1 map.

Salvador, A., 1991, Structure at the base and subcrop below Mesozoic marine section, Gulf of Mexico, in Salvador, A. (ed.), The Gulf of Mexico Basin: The Geological Society of America, The Geology of North America, v. J, Plate 3, 1:5,000,000.

Salvador, A., Westermann, G.E.G., Olóriz, F., Gordon, M.B., Gursky, H.-J., 1992, Meso-America, in Westerman, G.E.G. (ed.), The Jurassic of the Circum-Pacific, Cambridge University Press, 93121.

Santamaría-O., D., Ortuño A., F., Adatte, T., Ortiz-U., A., Riba-R., A, Franco-N., S., 1991, Evolución Geodinamica de la Cuenca de Sabinas y sus Implicaciones Petroleras Estado de Coahuila: Instituto Mexicano del Petroleo, Subdirección de Tecnología de Exploración, Gerencia de Investigación Aplicada a la Exploración, Tomo I, 209 p.

Scott, R.W., González-León, C.M., 1991, Paleontology and biostratigraphy of Cretaceous rocks, Lampazos area, Sonora, in PérezSegura, E., Jacques-Ayala, C. (eds.), Studies of Sonoran Geology: Geological Society of America, Special Publication 254, 51-67.

Schultz-Ela, D.D., Jackson, P.A., 1996, Relation of subsalt structures to suprasalt structures during extension: American Association of Petroleum Geologists, Bulletin, 80, 1,896-1,924.

Seager, W.R., 1983, Laramide wrench faults, basement-cored uplifts, and complementary basins in southern New Mexico: New Mexico Geology, 5, 69-76.

Seager, W.R., 1989, Geology beneath and around the West Potrillo basalts Doña Ana and Luna counties, New Mexico: New Mexico Geology, August 1989, 53-59.

Seager, W.R., Morgan, P., 1979, Rio Grande rift in southern New Mexico, west Texas, and northern Chihuahua, in Riecker, R.E. (ed.), Rio Grande Rift; Tectonics and Magmatism: American Geophysical Union, 87-106.

Seager, W.R., Mack, G.H., Raimonde, M.S., Ryan, R.G., 1986, Laramide basement-cored uplift and basins in south-central New Mexico: New Mexico Geological Society, $37^{\text {th }}$ Field Conference Guidebook 37, 123-130.

Sipperly, D.W., 1967, Tectonic history of Sierra del Alambre, northeastern Chihuahua, Mexico: University of Texas at Austin M.A. thesis, $78 \mathrm{p}$.

Silver, L.T., Anderson, T.H., 1974, Possible left-lateral early to middle Mesozoic disruption of the southwestern North American craton margin: Geological Society of America, Abstracts with Programs, 6, 955-956.

Sivils, D.J., 1987, Statigraphy and structure of Sierra de Palomas: Chihuahua, Mexico: Universidad Autónoma de Chihuahua, Facultad de Ingenieria and Sociedad Geológica Mexicana, Delegación Chihuahua, Gaceta Geológica, 1 (1), 176-202.

Smith, J.F. Jr., 1940, Stratigraphy and structure of the Devil Ridge area, Texas: Geological Society of America Bulletin, 51, 597637.

Sociedad Geológica Mexicana (Delegación Chihuahua), 1985, Plano Geológico Minero, Chihuahua, México, 1:500,000.

Stevens, J.B., Stevens, M.S., 1985, Basin and Range deformation and depositional timing, Trans-Pecos Texas, in Structure and Tectonics of Trans-Pecos Texas: West Texas Geological Society, Publication 85-81, 157-163.

Stevens, J.B., Stevens, M.S., 1990, Stratigraphy and major structuraltectonic events along and near the Rio Grande, Trans-Pecos Texas and adjacent Chihuahua and Coahuila, Mexico, in Geology of the Big Bend and Trans-Pecos Texas: South Texas Geological Society, Guidebook, 56-94.

Stewart, J.H., 1978, Basin-range structure in western North America, a review, in Smith, R.B., Eaton, G.P. (eds.), Cenozoic Tectonics and Regional Geophysics of the Western Cordillera: Geological Society of America, Memoir 152, 1-43.

Stewart, J.H., 1992, Late Proterozoic and Paleozoic southern margin of North America in northern Mexico, in Geology and Mineral Resources of Northern Sierra Madre Occidental, Mexico: El Paso Geological Society, 1992 Field Trip Guidebook, 291-299.

Stewart, J.H., 1998, Regional characteristics, tilt domains, and extensional history of the late Cenozoic Basin and Range province, 
western North America, in Faulds, J.E., Stewart, J.H. (eds.), Accomodation Zones and Transfer Zones; The Regional Segmentation of the Basin and Range Province: Geological Society of America, Special Paper 323, 47-74.

Stoyanow, A., 1949, Lower Cretaceous stratigraphy in southeastern Arizona: Geological Society of America, Memoir 38, 328 p.

Strain, W.S., 1980, Pleistocene rocks in El Paso and Hudspeth counties, Texas adjacent to Interstate Highway 10, in Trans-Pecos Region: New Mexico Geological Society, $31^{\text {st }}$ Field Conference Guidebook, p, 179-181.

Taff, J.A., 1891, The Cretaceous deposits of El Paso County: Texas Geological Survey Annual Report 2, 714-738.

Thompson, S. III, 1982, Oil and gas exploration wells in southwestern New Mexico, in Powers, R.B. (ed.), Geologic Studies of the Cordilleran Thrust Belt: Rocky Mountain Association of Geologists, II, 521-536.

Thompson, S. III, Bieberman, R.A., 1975, Oil and gas exploration wells in Doña Ana County, New Mexico, in Las Cruces Country: New Mexico Geological Society, 26 ${ }^{\text {th }}$ Field Conference Guidebook, 171-174.

Thompson, S. III, Tovar-R., J.C., Conley, J.N., 1978, Oil and gas exploration wells in the Pedregosa basin, in Land of Cochise: New Mexico Geological Society, $29^{\text {th }}$ Field Conference Guidebook, 331-342.

Tickner, B., 1987, Stratigraphic studies and microfacies analysis of the Jurassic succession, Malone Mountains; west Texas: University of Texas at Dallas, M.S. thesis, 204 p.

Titley, S.R., 1976, Evidence for a Mesozoic linear tectonic pattern in southeas tern Arizona: Arizona Geological Digest, X, 71-101.

Torres, R., Ruiz, J., Patchett, P.J., Grajales, J.M., 1999, Permo-Triassic continental arc in eastern Mexico; Tectonic implications for reconstruction of southern North America, in Bartolini, C., Wilson, J.L., Lawton, T.F. (eds.), Mesozoic Sedimentary and Tectonic History of North-Central Gulf of Mexico: Geological Society of America, Special Paper 340, 191-196.

Tovar-R, J., Vázques, H., Lozano, S., 1978, Interpretación integrada geológica-geofísica, porción norte de Chihuahua: Asociación Mexicana de Geólogos Petroleros, Boletín, XXX, 59-132.

Tucholke, B.E., Schouten, H., 1988, Kane Fracture Zone: Marine Ge ophysical Researches, 10, 1-39.

Twiss, P.C., 1959a, Geology of Van Horn Mountains, Texas: Texas Bureau of Economic Geology, Geologic Quadrangle Map No. 23.

Twiss, P.C., 1959b, Geology of Van Horn Mountains, Texas: University of Texas at Austin, Ph.D. dissertation 234 p.

Underwood, J.R., Jr., 1962, Geology of Eagle Mountains and vicinity, Trans-Pecos Texas: University of Texas at Austin, Ph.D. dissertation $559 \mathrm{p}$.
Underwood, J.R., Jr., 1963, Geology of Eagle Mountains and vicinity, Trans-Pecos Texas: Texas Bureau of Economic Geology, Geologic Quadrangle Map No. 24.

Uphoff, T.L., 1978, Subsurface stratigraphy and structure of the Mesilla and Hueco bolsons, El Paso region, Texas and New Mexico: University of Texas at El Paso M.S. thesis, $66 \mathrm{p}$.

Vedder, L.K, 1984 Stratigraphic relationships between the Late Jurassic Canelo Hills Volcanics and the Glance Conglomerate, southeastern Arizona: University of Arizona, M.S. thesis, 129 p.

Ward, C.A., 1977, Structural geology and tectonic history of Paleozo ic rocks in the Sierra de Las Monillas, east-central Chihuahua, Mexico: Texas Christian University, M.S. thesis, 54 p.

Webb, D.S., 1969, Facets of the geology of the Sierra del Presidio area, north-central Chihuahua, in The Border Region: New Mexico Geological Society, 29 ${ }^{\text {th }}$ Field Conference Guidebook, 182-185.

Webster, R.E., 1980, Structural analysis of Devils River uplift-southern Val Verde Basin, southwestern Texas: American Association of Petroleum Geologists, Bulletin, 64, 221-241.

Wiltschko, D., Eastman, D., 1983, Role of basement warps and faults in localizing thrust fault ramps, in Hatcher, R.D., Jr. (ed.), Tectonics and Geophysics of Mountain Chains: Geological Society of America, Memoir 158, 177-190.

Wolleben, J.A., 1966, Biostratigraphy of the Ojinaga and San Carlos formations of west Texas and northeastern Chihuahua: University of Texas at Austin, Ph.D. dissertation, $62 \mathrm{p}$.

Woodward, L.A., Anderson, O.J., Lucas, S.G., 1999, Late Paleozoic right-slip faults in the Ancestral Rocky, Mountains, in Albuquerque Geology: New Mexico Geological Society, 50 ${ }^{\text {th }}$ Field Conference, $149-153$.

Yeager, J.C., 1960, Stratigraphy of southern Sierra Pilares, Municipio de Ojinaga, Chihuahua, Mexico: University of Texas at Austin M.A. thesis, $116 \mathrm{p}$.

Young, K., 1969, Ammonite zones of northern Chihuahua, in The Border Region: New Mexico Geological Society, $20^{\text {th }}$ Field Conference Guidebook, 97-101.

Zeller, R.A.Jr., 1965, Stratigraphy of the Big Hatchet Mountains area, New Mexico: New Mexico Bureau of Mines and Mineral Resources, Memoir 16, $128 \mathrm{p}$.

Zeller, R.A.Jr., 1970, Geology of Little Hatchet Mountains, Hidalgo and Grant Counties, New Mexico: New Mexico Bureau of Mines and Mineral Resources, Bulletin 96, 23 p

Manuscript received: April 25, 2001

Corrected manuscript received: October 18, 2001

Manuscript accepted: February 15, 2002 